\title{
Artefakty interpretované jako „lékařské nástroje“ z doby železné nebo římské na území dnešní Čr a naddunajské části Dolního Rakouska
}

Artefacts identified as "medical instruments" of the Iron Age or the Roman Age from, what is known today as, the Czech Republic, Slovakia and Lower Austria - North of the Danube

\section{Lucie Burešová}

\begin{abstract}
Abstrakt
Cílem článku je předložit katalog artefaktů z doby železné a římské nalezených na území dnešní České republiky, Slovenské republiky a naddunajské části Dolního Rakouska, které byly interpretovány jako „lékařské nástroje“. Je podán stručný přehled druhového a tvarového spektra takto interpretovaných artefaktů v prostředí Evropy a je sestaven katalog těchto artefaktů z doby železné a římské na zkoumaném území. U jednotlivých artefaktů je kriticky přehodnoceno, zda mohly sloužit k léčebným nebo diagnostickým účelům.
\end{abstract}

\begin{abstract}
The article presents a catalogue of artefacts identified as "medical instruments" of the Iron Age, or the Roman Age, from what is known today as the Czech Republic, Slovakia and the Lower Austria - North of the Danube. A brief overview of the types and the variety of shapes of the artefacts, interpreted as "medical instruments" in the European milieu, was presented and a catalogue of artefacts of the Iron Age or the Roman Age, from the territory under examination was compiled. The individual artefacts were critically reviewed, and it was decided whether they could have been used for therapeutic or diagnostic purposes.
\end{abstract}

Klíčová slova: lékařské nástroje - doba římská - doba železná - skalpel - nůž - jehla Klíčová slova: medical instruments - Roman Age - Iron Age - scalpel - knife - needle

DOI: $10.14712 / 25707213.2021 .1$

\section{1. Úvod}

Pro archeologii medicíny je žádoucí disponovat katalogy nástrojů, které sloužily k diagnostickým či léčebným výkonům $\mathrm{v}$ různých historických obdobích, protože poskytují bázi pro vyhledávání analogií nalezených artefaktů a přispívají tak k doložení výskytu osob praktikujících výkony pomocí těchto artefaktů na zkoumaném území.

Archeologie medicíny se aktuálně zabývá oblastí materiálového výzkumu, především instrumentů, ikonografie a dalších projevů chirurgie a medicíny v minulosti, oblastí identifikace a diagnostiky patologií nebo neobvyklých příkladů chirurgických zákroků (Shaw - Sykes 2018). Rozvíjí se v souladu s aktuálním trendem v archeologii obecně, je kladen důraz na multidisciplinární spolupráci a cílí na př́nosy lékařské a chirurgické historie pro moderní vědu (Faria 2015). Archeologický výzkum medicíny a péče o nemocné má dlouhodobě tendenci zkoumat formální nástroje a procesy, nikoliv obor v širších souvislostech (Shaw - Sykes 2018). Na souvislosti však lze usuzovat až na základě validních informací. Protože o zkoumaném území neexistuje dostatek informací z písemných pramenů, neexistují kompletní katalogy nástrojů, které sloužily k diagnostickým či léčebným výkonům, a panují neshody na tom, které $\mathrm{z}$ interpretovaných artefaktů skutečně mohly sloužit $\mathrm{k}$ léčebným výkonům, přehled artefaktů a jejich kritické přezkoumání může sloužit jako solidní základ pro další analytické a syntetické aktivity badatelů. Analýza materiálu nemůže samostatně zodpovědět otázky dějin oboru, ale je nezbytnou potřebou v situaci, kdy katalog z definovaného území neexistuje. Rozvoj archeologie medicíny je brzděn také nepřesnou a nejednotnou terminologií a následující snahy 
by proto měly být upnuty i ke sjednocení termínů a pojmů. Materiálový př́stup je nutný k doplnění poznatků z lokalit, kde artefakty doposud nebyly přezkoumány jako celek, a badatelé se zaměřují pouze na dílčí jednotky, kterým přisuzují účel k léčbě zcela bez kontextu.

Stěžejní nevyřešené otázky archeologie medicíny v našem prostř̌edí představují možnosti rozeznání místních nástrojů od římských a rozeznání artefaktů z doby římské od středověkých. Prameny poznání medicíny u barbarů jsou omezené. Samostatným problémem je nálezový kontext nástrojů v barbariku. Neexistuje katalog všech artefaktů interpretovaných jako „lékařské/medicínské nástroje“, „chirurgické nástroje“ nebo nástroje pro léčebné výkony z území dnešní ČR, SR a naddunajské části Dolního Rakouska. Označování artefaktů interpretovaných jako nástroje určené $\mathrm{k}$ léčebným výkonům není jednotné. Cílem textu je předložit katalog artefaktů z doby železné a římské nalezených na území dnešní České republiky, Slovenské republiky a naddunajské části Dolního Rakouska, které byly, resp. mohou být na základě analogií, interpretovány jako lékařské nástroje, a poskytnout kritické přehodnocení těchto pramenů.

\section{Metody}

V předloženém textu je využita rešerše zdrojů a sestavení katalogu, materiálová analýza a kritické přehodnocení interpretací. Výzkumnou otázkou je, které z artefaktů nalezených na území dnešní ČR, SR a naddunajské části Dolního Rakouska, u nichž je předpokládán původ v době halštatské, laténské a římské, mohly sloužit k diagnostickým a léčebným výkonům.

Hlavním výstupem článku je katalog artefaktů z doby železné a římské, které byly interpretovány jako lékařské nástroje a jsou uloženy ve sbírkotvorných institucích v České republice, Slovenské republice a naddunajské části Dolního Rakouska, nebo jsou uloženy v soukromých sbírkách na území těchto států. Katalog je doplněn o zjištěné artefakty doposud nepovažované za lékařské nástroje, ale odpovídající analogiím z našeho a římského prostředí, které jsou vyhledány ve vybraných muzeích v České republice. Jednotlivé artefakty jsou dále porovnávány s analogiemi a je kriticky zhodnocena jejich původní interpretace.

Za nástroje $\mathrm{k}$ léčebným a diagnostickým výkonům jsou pro účely tohoto textu považovány kovové artefakty, u kterých je badateli předpokládáno užívání $\mathrm{k}$ činnostem spojeným s diagnostikou a léčbou chorob v rámci organizované činnosti, kterou označují za lékařství nebo chirurgii. V práci jsou kriticky posouzeny jednotlivé artefakty s vědomím, že ani existence analogie nevylučuje možnost, že byl arte- fakt užíván jiným než badateli předpokládaným zpo̊sobem, jde i o artefakty, které mohly být v minulosti interpretovány mylně. Geografická oblast zájmu je zvolena s ohledem na fakt, že v době železné a římské mohly tyto $\mathrm{v}$ současnosti hranicemi oddělené země pojit těsné vztahy (resp. tvořit jeden celek). Napovídá tomu např́íklad rozptyl artefaktů v době římské (např. Elschek 2017). Zasazení tématu do doby železné a římské plyne především ze zájmu předložit materiál, který může být srovnáván s obdobím počátků vědeckého pojetí antické medicíny. Fakticky se tak jedná o období od roku 800 př. n. l. do roku 400 n. l. na území střední Evropy. Vznik prvních paradigmat $\mathrm{v}$ rámci tzv. západní medicíny je možné pozorovat v Řecku od 5. stol. př. n. 1., práce se tedy soustředí zejména na dobu od vzniku těchto prvních paradigmat $\mathrm{v}$ rámci cyklu rozvoje vědy $\mathrm{s}$ jistým přesahem do předparadigmatického období. Zkoumané období je ohraničeno začátkem doby halštatské a koncem doby římské na definovaném území, jsou sledovány artefakty z území dnešní ČR, SR a naddunajské části Dolního Rakouska z období od roku 800 př. n. 1 . do roku 400 n. 1 .

\section{Archeologické prameny}

O jednotlivých artefaktech je možné se dozvědět z informací publikovaných archeology nebo historiky, pouze určitá část artefaktů je vystavena v muzeích. Rozsáhlá sbírka nástrojů a jiného vybavení pro diagnostiku a léčbu chorob je umístěna v Britském muzeu, nálezy z Pompejí jsou uloženy v Národním archeologickém muzeu v Neapoli, nálezy z Manchingu v Městském muzeu v Ingolstadtu. Nejstarší nástroje ve sbírkách Zdravotnického muzea Národní lékařské knihovny ČR pocházejí z 19. století, tři položky inventáře představují kopie bronzových nálezů (vyrobené v 19. století) z Pompejí (výběr z nálezů z Casa del Chirurgo). Starší artefakty se nacházejí jednotlivě ve sbírkách muzeí, která nemají vyhrazená oddělení nebo části pro archeologii medicíny.

Největší katalogy medicínských nástrojů sestavil 7. S. Milne (1907) a později Ernst Künzl (Künzl Hassel - Künzl 1983). Souhrn toaletních a lékařských nástrojů ze švýcarské lokality Augst a Kaiseraugst připravila Emilie Riha $(1986 ;$ 1990), Kordula Gostenčnik (2001) přispěla k poznání problematiky analýzou nástrojů z Magdalensbergu. Na díla J. S. Milna a E. Künzla navázal souhrnným dílem Lazrence J. Bliquez (2014).

\subsection{Kritika pramenů}

Chirurgické nástroje se na zkoumaném území vyskytují často bez kontextu. Velké množství artefaktů je 
získáno povrchovými sběry nebo laickou detektorovou prospekcí. S každým artefaktem se pracuje jednotlivě, $\mathrm{v}$ publikacích často není reflektováno, zda jiné indicie nasvědčují př́ítomnosti specializované osoby (chirurga) na zkoumané lokalitě v dané době.

Ze zkoumaného území je získáno pouze malé množství artefaktů, které lze bez vážných pochybností spojovat s léčbou. Náhodně nalezené artefakty (interpretované jako chirurgické nástroje) na lokalitách s doloženým osídlením v době laténské nebo ř́mské mají často prokázané využívání také v jiných obdobích. Atraktivita nálezu chirurgického nástroje z daných historických období může rovněž svádět $\mathrm{k}$ neuvážené interpretaci. Podobnosti v nástrojích je možné zaznamenat např́íklad i v pozdním středověku (např. Florea 2013, 154) nebo novověku (napřr. Heisters 1724; Brambilla, 1781). Ačkoliv bylo dění v oblasti medicíny a chirurgie v tomto období bouřlivé, mistři na univerzitách významnou měrou vycházeli z antické vzdělanosti (vliv dochovaných Galénových děl) a to se pravděpodobně projevilo i na nástrojovém vybavení.

K. Gostenčnik $(2002,163)$ na souboru z Magdalensbergu také zjistila, že typologická pozorování nemají současně chronologický význam. Jednotlivé nástroje bez známého kontextu je tedy obtížné správně datovat.

Pro rozeznání nástrojů místní výroby od importovaných neexistují exaktní metody. Možným způsobem se tedy jeví pouze srovnávání artefaktů s analogiemi. Na základě dřívějších nálezů byly popsány některé obecné vlastnosti nástrojů $\mathrm{k}$ léčebným výkonům vyráběných $\mathrm{v}$ prostředí barbarika od 4 . do 1 . st. př. n. l., kdy se měl projevit vliv přenosu řecké vzdělanosti na území střední Evropy, ale samotné praktiky zůstávaly značně nezávislé na tomto vlivu (Künzl, E. 1995, 224).

\subsection{Nálezové kontexty}

Jednotlivé nástroje, kterým badatelé v dříve publikovaných pracích přisoudili účel $\mathrm{k}$ chirurgické léčbě, jsou spojeny s lokalitami římských táborů, kupř́kladu s Oberleiserbergem (Kern 1996, 388) a Mušovem (Tejral 1971, 37), místem nálezů importů jsou římské vily (respektive vily v římském stylu), např́klad v Cíferi-Páci (Kolník 2004, 210), velké množství artefaktů je však zcela bez známého kontextu. Samostatným problémem je nálezový kontext nástrojů v barbariku. Instrumenty je možné snáze interpretovat, pokud jsou nalézány jako soubory nebo $\mathrm{v}$ hrobových výbavách. Je nutné vzít v úvahu, že př́tomnost nástroje v hrobě není důkazem uložení „lékaře/chirurga" a problematické je rovněž usuzovat na základě odhadovaného původu artefaktu také na původ pohřbeného.
Hroby jsou zásadním zdrojem nástrojů řeckých a římských artefaktů interpretovaných jako nástroje pro léčbu a diagnostiku. $\mathrm{Z}$ toho se usuzuje, že období ŕímské říše mohlo být specifické tím, že byli chirurgové pohřbíváni se svým instrumentáriem, v jiných obdobích není tento fenomén shledáván (Bliquez 2003). Hroby, o nichž se hovoř́ jako o chirurgických, jsou v římském Rakousku vzácné a tento fenomén se vyskytuje pouze v Carnuntu (Gostenčnik 2002, 164). V situaci, kdy není hrob označen, nebo $\mathrm{k}$ němu neexistují jiné informace, které $\mathrm{s}$ jistotou doloží, že v hrobě je uložen specialista v jejich užívání, ovšem není možné pouhou př́tomnost nástrojů považovat za důkaz.

Řada artefaktů, o nichž je uvažováno jako o chirurgických nástrojích, je zcela bez kontextu, tedy pořízena $\mathrm{v}$ rámci sběrů nebo laické detektorové prospekce. Vzhledem k tomu, že se jedná zpravidla o kovové artefakty, rozvoj detektoringu v minulých letech hraje významnou roli. Obzvláště některé artefakty, snadno identifikovatelné kvůli tvaru (spatula, skalpel), mohou být ztraceny na černém trhu.

\section{Názvosloví a morfologie nástrojů}

Nástroje užívané k operačním výkonům jsou nazývány chirurgické. M. Duda a B. Niederle $(2000,40)$ považují termín nástroj za analogický k termínu instrument. Vychází z latinského instrūmentum, které je překládáno jako nástroj či nářadí. Slovo instrūmentārium je pak souborný název pro chirurgické nástroje (Kábrt - Kábrt 2004, 513). V tomto významu jsou v následujícím textu využívány. Slovo nástroj je tak užíváno v obecném významu, slovo instrument pak $\mathrm{v}$ přímém spojení s chirurgií.

V článku jsou blíže popsány pouze ty nástroje, jejichž exempláře již byly na zkoumaném území identifikovány. Některé další fyzicky nalezené artefakty na jiných lokalitách, nebo známé pouze z písemných pramenů, jsou v textu uvedeny názvem, u některých jsou zmíněny i určité vlastnosti.

\subsection{Kosmetické nástroje versus chirurgické nástroje}

Kosmetické nástroje nedokládají specializovanou činnost, jejich zařazení mezi chirurgické či směšování s chirurgickými tedy není opodstatněné. Problematiku výstižně vysvětlila $K$. Gostenčnik $(2013,95)$, když zvolila $\mathrm{k}$ rozlišení artefaktů spojených s organizovanou činností, oproti artefaktům užívaným širokou veřejností např. k osobní hygieně, tř́dění nástrojů na primární a sekundární. V samé podstatě je tak možné primární nástroje př́mo spojovat s činnostmi „lékařư (je nutné poznamenat, že autorka 
ve svém textu užívá moderního významu pojmu „lékařství“, tedy že nereflektuje oddělenou existenci a náplň chirurgie a medicíny). Sekundární nástroje označuje jako „toaletní“, tedy pro každodenní užití. Uvádí dále, že většina nálezů označovaných v archeologické literatuře jako „lékařské nástroje“ jsou ve skutečnosti toaletní potřeby. Za nástroje primárně určené $\mathrm{k}$ léčebným výkonům jsou tedy považovány např. skalpely, chirurgické nože, katetry, kostní dláta, lékařské pinzety a svorky, jehly k řešení katarakty, lancety na pouštění žilou, spekula, speciální nástroje (pily ke kraniotomiím a podobně), zubní a kostní kleště, litotomické nástroje, za sekundární pak lžíce, špachtle a ušní sondy, balzamária, krabičky na léčiva a kulaté plechové nádoby, pinzety, třecí desky (Gostenčnik 2013, 95), ale také např. párátka a strigily (Weller - Kaiser - Heynowski 2016, 39, 45). Emilie Riha (1986) provedla již dříve roztřídění materiálu při zpracování nálezů z Augstu do tří kategorií. Rozlišila čistě toaletní nástroje, nástroje pro lékařské a kosmetické účely a čistě lékařské a speciální nástroje. Vzniká tak ovšem střední kategorie, která neumožňuje rozhodnout, zda je vhodné uvažovat o př́tomnosti specializovaných aktivit na lokalitě, či nikoliv.

Různé sondy, jako jsou špachtle nebo lžíce nebo nesčetné ušní lžíce, mohly být používány jak v kosmetice, tak v chirurgii a interpretace tedy závisí na kontextu nálezu (Gostenčnik 2013, 95). Ten však často zcela chybí, nebot' řada artefaktů byla nalezena laiky detektorovými průzkumy. Mezi nástroje osobní hygieny patři rovněž strigila (obr. 1: 1), zrcátko a břitva. Na zkoumaném území byla nalezena řada nástrojů, které je vzhledem ke kontextu možné přiřadit $\mathrm{k}$ sekundárním nástrojům. Př́́kladem je spatula a třecí destička z Mušova (obr. 1: 2). Nález těchto dvou artefaktů vyvolal řadu otázek. E. Künzl považuje nález třecí destičky (místní výroby) se spatulou (u které předpokládá, že jde o originální ř́mský výrobek z let 50 až 150 n. l.) v hrobě za důkaz uložení germánského př́śslušníka elity a srovnává tento kontext nikoliv s „hroby lékařư “, ale s hroby dunajských provincií bohatě vybavenými příslušenstvím a kosmetickým vybavením (Peška - Tejral - Von Carnap-Bornheim 2002). U. Weller, H. Kaiser a R. Heynowski (2016) zařadili do svého katalogu i hřebeny, břitvy a zrcadla.

\subsection{Chirurgické nástroje řeckého a římského původu}

$\mathrm{V}$ posledních třech desetiletích značnou měrou vzrostl zájem o poznání antické chirurgie. Jako prameny posloužily nové archeologické nálezy a údaje z písemných pramenů (principy interního lékařství jsou $\mathrm{z}$ většiny archeologicky nerozpoznatelné a jsou známy pouze ze spisů, především z hippokratov- ských, a řada z nich je přenesena do moderní medicíny). Výzkumy odhalily více než 120 různých operací prováděných za existence římské říše a podle Galéna existovala operace pro každou část těla. Valná většina výkonů vyžadovala použití skalpelu, popřípadě jiného nástroje z kovu, včetně katétrů, výjimečně prostředků z jiných materiálů, jako jsou nádobky či baňky (Bliquez 2014, 1).

$S$ větší opatrností při interpretaci je nutné přistupovat $\mathrm{k}$ artefaktům, které mohly sloužit k diagnostice či léčbě chorob a místo jejich výroby je odhadováno na území barbarika. $\mathrm{Z}$ písemných pramenů totiž nejsou známy jasné informace o léčebných praktikách na tomto území a není zřejmé, kdo nástroje používal a jakým způsobem. Plinius starší hovoří o existenci druidů, jakožto kouzelníků a lékařo (Plinius, NH, 30, 4; Bostock - Riley 1855), o rostlinách, které pěstovali (Plinius, NH, 16, 95; Bostock - Riley 1855) a jejich určitých účincích (Plinius, NH, 24, 62; Bostock - Riley 1855).

Názvosloví jednotlivých nástrojů je nejednotné především z důvodu přepisů lékařských textů. Odlišnosti nastaly již při překladech z řečtiny do latiny, kdy někteří autoři ponechávají předmětům řecká označení, jiní je nahrazují latinskými názvy. Středověké texty pracují s latinou, u nástrojů, kde zřejmě existovala kontinuita užívání, jsou často uváděny i řecké varianty názvů a tento fenomén se v řadě př́ípadů dochoval do současnosti (Bliquez 2014, 3).

Informace $\mathrm{z}$ písemných pramenů o tom, že většina antických lékařů získala dovednosti vyučením, a to často ve spojení s vojenskou službou nebo v rámci farmaceutického bádání, mohou být stěžejní pro vysvětlení nálezových kontextů. Galén pocházel z bohatých poměrů a mohl si tak dovolit navštěvovat přednášky prominentních lékařơ na Kóu nebo v Alexandrii, ale i pořízení samotných nástrojů (Bliquez 2014, 8). Poznatky o Galénovi jsou sice nepostradatelné pro pochopení dobové situace, jde však o elitního jedince a praxe běžných lékařo mohla být odlišná. Zásadní pro vysvětlení každodennosti lékařů jsou tedy archeologické nálezy, v popředí s artefakty z Pompejí, z antické Marcianopole v Bulharsku a z Rimini. V Pompejích bylo zjištěno více než 20 míst, ve kterých pravděpodobně byly prováděny chirurgické či obecně léčebné výkony. Množství a spektrum nástrojů např́íklad v Casa del Medico Nuovo vede $\mathrm{k}$ závěrům, že se jednalo o místo plnohodnotné praxe více lékařů (Bliquez 2014, 12). Vzhledem k významu válečné chirurgie (chirurgie v bojových a dalších výjimečných podmínkách) v antice patří nástroje $\mathrm{k}$ nálezům také v kontextu římských vojenských pevností a táborů. Na lokalitě Vindonissa ve Švýcarsku bylo nalezeno celkem 326 nástrojů ve 22 polohách (Baker 2004). Nejasné zůstávají okolnosti uložení nástrojů se zemřelými ve formě hrobové výbavy, situace také 
nevypovídá o tom, zda jde o plné instrumentárium či pouze jeho část (Künzl 1983).

Má se za to, že lékařská praxe, tak aby umožnila provedení většiny známých výkonů, mohla být prováděna s následujícím minimálním nástrojovým vybavením: skalpel, ostrý retraktor, kleště, jehla či sonda a špachtle. To dokládají i přenosné soupravy nalezené např́klad na Piazza del Anfiteatro v Pompejích, v hrobě ve Wehringenu v Bavorsku a v Herculaneu. Lékárenská praxe vyžadovala špachtle, liguly, lžičky, nádoby na léky a brusné kameny (Bliquez 2014, 12). V Mohučském muzeu je uložena např́klad řada lékových nádob složených ze dvou válcových pouzder, ke kterým je připojeno další pouzdro na nástroj k mísení a aplikaci. Nádoby jsou opatřeny víky připojenými řetízkem (Künzl 2002, tab. 38-40).

Galén popisuje důležitost výrobců nástrojů. Reliéfní zobrazení z ikonografie dokládají existenci specializovaných obchodů. Výroba nástrojů byla doložena v Pompejích, šlo o dílnu vyrábějící chirurgické nástroje z kovu, dále je znám obchod v Dionu v Řecku, kam byla dle badatelů dovezena k opravě gynekologická zrcadla. Špachtle, lžíce, sondy s olivkami na koncích (dipyrene) a pinzety mohly být používány i laiky a zřejmě tedy bylo možné je pořídit i u kováře. Pravděpodobná je i možnost výroby specializovaných nástrojů samotnými lékaři (což je možné sledovat i později v průběhu novodobé historie lékařství), Galén hovoří o svém vlastním navrhování modelů nových typů nástrojů pro zpracování kováři (Bliquez 2014, $14)$. Nástroje byly vyráběny převážně z bronzu nebo mosazi. Často jsou oboustranné, např́iklad špachtle a lžičky jsou doplněny olivkami pro broušení, sondáž a kauterizaci, skalpely jsou doplněny tupými disektory, jehly pak retraktory. Čepele nástrojů pro řezání a propichování (např́klad skalpely, jehly, dláta) byly často ze železa nebo oceli s cínovými nebo olověnými spoji (Bliquez 2014, 16). Např́klad Galén požaduje své nástroje z norické oceli a nejtěžšího železa (Baker 2013, 156). Většina dochovaných hmotných pramenů jsou jednodílné železné nástroje a kontrastují tak s římskou tendencí vyrábět jednodílné bronzové nástroje nebo nástroje dvoudílné z bronzu a železa (Jakielski - Notis 2000). Kromě kovových artefaktů je možné výjimečně nalézt kostěné sondy a krabice, skleněné a hliněné misky, kádinky a sklenice, ojediněle dřevěné sondy a nádoby (Bliquez 2014, 17).

Nástroje byly vyráběny odléváním, kováním a tvářením za studena (Bliquez 2014, 17). V současnosti jsou nástroje vyráběny z oceli (tepelným zpracováním, tvářením za studena a s využitím dalších povrchových úprav), z neželezných kovů (titan, dural, zlato), slinutých karbidů a plastů (Firků - Pazdziora 2006). Rukojeti skalpelů a sekvestrační kleště byly odlévány do forem, katétry a trubičky řezány, vybíjeny a tvarovány z fólie, nástroje ze železa a oceli (čepele) pak kovány. Možné je i použití soustruhů pro závity na gynekologických zrcadlech. Některé nástroje jsou zdobené tauzováním, niellem, inkrustací stříbrem nebo korintským bronzem (Bliquez 2014, 18-19). Informace o specifickém zdobení chirurgických nástrojů může být cenná při jejich interpretaci, zdobené však mohou být i jiné nástroje.

$\mathrm{Z}$ archeologických nálezů a písemných pramenů lze sestavit přehled základních instrumentů. Nálezy v řeckém a římském prostředí zahrnují baňky (na baňkování), nástroje na řezání a propichování, tedy nože (přesněji lékařské nože, také smile, machaira, machairis, sideros), nožíky, skalpely, jehly, trojúhelníkové jehly, kautery, dále sondy, špachtle (spatula, také tyčovité rhabdos a atraktos) a lžičky, gynekologická a anální zrcadla, dilatátory (také specializovaný molubdion), katetry, oční sondy, vidlicovité nástroje na obracení (Bliquez 2014; Gostenčnik 2004). Z Galénova popisu skalpelů vyplývá, že čepel umístěná v těle nástroje (corpus) mưže být špičatá nebo široká, ostrá nebo extrémně ostrá, velmi ostrá a jemná, zakřivená, zakřivená a široká ve špičce, nebo ve tvaru kapky (Bliquez 2014). Kostní a zubní nástroje jsou vrtáky, páky (také prion, pro trepanaci prion kharaktos), pily, škrabky (také xyster, který má nejasné vysvětlení), kleště a retraktory, tzv. extraktory kostí (osteologon), háky (mimo jiné také kotvovitá sonda ankuromele). Mezi gynekologické instrumenty patří také nástroj na destrukci embrya (piestron), nástroje k vytahování zbytků zárodku (helkuster) a trubice (klyster). Účely a názvy těchto nástrojů jsou známy z písemných pramenů (Gostenčnik 2004; Bliquez 2014).

Retraktory, rozvěrače/rozvěráky (rovněž ekatéry) a háky slouží k roztahování a rozevírání operační rány. Do značné míry poukazují na nutnost zapojení asistenta při operačním výkonu. Asistent používá tyto nástroje ke zpř́ístupnění a zpřehlednění operačního pole chirurgovi. Háky a háčky mohou sloužit dle tvaru a velikosti $\mathrm{k}$ různým účelům, např. háčky na šlachy, háky na kosti. V současném i historickém instrumentáriu je možné nalézt tupé i ostré varianty. Ostré jsou samozřejmě spojeny s rizikem perforace tkáně/orgánu, mohou ale posloužit v povrchových vrstvách. Ekatéry v moderním instrumentáriu zůstávají ve své poloze díky zámečku. Tupé a ostré háky se někdy navzájem kombinují a vytvářejí oboustranný nástroj, dva háčky jsou pak zpravidla vloženy do rukojeti (Gostenčnik 2002, 166).

Dochovány jsou také kovové mužské katetry (či jejich fragmenty) se zakřivením ve tvaru písmene S s doposud viditelnými otvory k odlučování obsahu močového měchýře (Gostenčnik 2002, 166) a př́ipadně $\mathrm{k}$ inserci tekutiny $\mathrm{k}$ výplachům. Jde o katetry/ cévky jednocestné. Jakoukoliv déletrvající katetrizaci lze vyloučit (cévka by v močové trubici nesetrvala bez zajištění, katetrizovaný jedinec by se nemohl 
pohnout bez rizika poškození tkání, delší tlak kovové cévky na tkáně by působil destruktivně). Z dnešního pohledu nepředstavuje močový katetr chirurgický nástroj, ale je považován za zdravotnický prostředek. Katetrizace je invazivním výkonem (Vytejčková et al. 2015, 124). Zánětlivá onemocnění močových cest a řešení močových kamenů jsou ve starověké lékařské literatuře běžným tématem, kameny byly podle popisů odstraňovány chirurgicky (Gostenčnik 2002, 167). Katetrizace močového měchýře je spojena s řadou rizik (Vytejčková et al. 2015, 124), která byla použitím kovového nebo dřevěného katetru umocněna. Riziko infekčních komplikací je rovněž zvýšeno poraněním při zavádění katetru (ostré hrany, popř. i tř́isky u dřevěného katetru).

Nálezy nástrojů z římského prostředí se v signifikantním počtu objevují i v archeologických situacích na území střední Evropy. Na lokalitě Magdalensberg bylo nalezeno téměř 125 nástrojů ze slitin mědi (Gostenčnik 2004, 370). T. Kolník předpokládá, že výskyt chirurgických nástrojů ve střední Evropě vypovídá o silném vlivu římsko-provinciálního prostředí a oboustranných kontaktech. Stupeň romanizace (v Čechách se o romanizaci hovořit nedá) mohl být podle něj na slovenském území silnější, než je z archeologických nálezů zřejmé (Kolník 2004).

\subsection{Znaky pramenů}

Nálezy importovaných nástrojů z římského prostředí dokládají kontakty s antickým světem a jeho hmotnou kulturou i praktikami, existují však nástroje typické tvarem a složením (a zároveň antropologickými doklady realizace technik) na území barbarika. Např. E. Künzl $(1995,222)$ označuje pily na trepanaci za specialitu Keltů, přičemž nachází železné i bronzové exempláře. Uvádí dále, že nástroje $\mathrm{z}$ hrobů LT C jsou místní produkce, jsou vyrobeny ze železa a kovářem velmi dovedně konstruovány $\mathrm{k}$ operačním výkonům, přičemž helenistický vliv na nich není patrný (Künzl, E. 1995, 223).

V období LT D se začaly do barbarika dovážet spatuly, pravděpodobně z Itálie. Z tohoto období zde chybí železné nástroje. Lokální nástroje v Galii, jižním Německu, dunajských zemích a Británii zmizely nejpozději při dobývání Římany, kdy bylo barbarikum téměř zcela pohlceno vlivem římské říše. Provádění vlastních léčebných praktik, do značné míry nezávislých na řeckém vlivu, je možné na území barbarika odhadovat od 4. do 1. st. př. n. 1. (Künzl, E. 1995, 224).

Bližší vhled do vnímání instrumentů ve zkoumaném období poskytují některé písemné prameny. Všechny nástroje měly být dobře přizpůsobeny pro použití velikostí, hmotností a precizností, konkrétní slitiny mědi měly být používány pouze pro určité typy nástrojů. Pro návštěvy (vizity, kolečka) pacientů mohly být některé základní nástroje uloženy v přenosném kufř́íku. Některé nástroje měly být pro práci v terénu uchovávány v jakémsi cestovním balení (parexodos; Bliquez 2003).

Ve zkoumané geografické oblasti jsou známy nálezy artefaktů interpretovaných jako skalpely, lancetovité a chirurgické nože, špachtle, jehly, pinzety a trepanační pily. Tyto jednotlivé nástroje a „zdravotnické“ prostředky (z dnešního pohledu) prošly mezi svou první doposud známou podobou a dnešní podobou určitým vývojem. Úplný obraz situace na definovaném území v době železné a římské tvoří nástroje místní produkce a nástroje importované.

Nástroje jsou tvořeny funkční (neboli pracovní) částí a pomocnou (neboli úchopovou) částí. Podle pracovní části se pak rozeznávají nástroje ostré a tupé. Nástroje pohyblivé pak mají také tzv. zámek, tedy např. čep, který spojuje pohyblivá ramena kleští a podobně (Duda-Niederle 2000, 40). Současné pojímání medicíny ovlivňuje pohled badatelů na předchozí období. Kupříkladu používání termínu „chirurgická pinzeta" v katalozích artefaktů neodpovídá specifické vlastnosti chirurgické pinzety v dnešním instrumentáriu, která se od tzv. anatomické pinzety liší př́tomností zoubků na konci funkční části. Zachycení podoby nástrojů používaných v 18. a 19. století však poskytuje vhled do situace, ve které byly realizovány první výzkumy Pompejí a Herculanea, nástroje začátku 20. století pak reflektují stav známý J. L. Píčovi při výzkumu Stradonic.

\subsubsection{Skalpel a nůž}

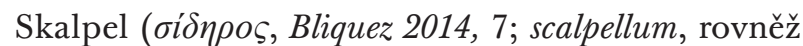
„nůž chirurgický“, Kábrt - Kábrt 2004, 842) patří mezi základní nástroje. Je tvořen ostrou pracovní částí a dobře uchopitelnou pomocnou částí obvykle vybavenou zdrsněním části povrchu $\mathrm{k}$ dosažení bezpečného držení. Patř́ mezi nejčastěji nalézané chirurgické nástroje. Téměř každá nalezená sada chirurgických nástrojů obsahuje alespoň jeden kus. Primárním účelem skalpelu je rozříznutí, proříznutí a vyříznutí tkání (Bliquez 2014, 72). Standardní skalpel pocházející z římské říše se skládá z obdélníkového držadla ze slitiny mědi a s čepelí ze železa ve tvaru listu (Bliquez 2014, 72). Skalpely byly nalezeny v mnoha variantách a objevují se v ikonografických pramenech. Čepele nebývají vždy zachovány, ale jsou známy exempláře skalpelů s různými tvary a rozměry čepelí (Gostenčnik 2013, 96). Skalpely mají velmi specifický tvar, je možné je však zaměnit za nože určené pro jinou činnost. V nálezovém fondu doby římské je vhodné je odlišit především od břitev určených k holení. 
Členění na nože a skalpely v katalozích archeologů není jednotné. V dnešním instrumentáriu se s názvem „nůž “ setkáváme např. u amputačního nože, nebo transplantačního nože. Prakticky tedy u nástrojů s dlouhou čepelí. V katalozích artefaktů délka čepele není reflektována, badatelé přiřazují nástroje dle vlastního úsudku. V hippokratovském

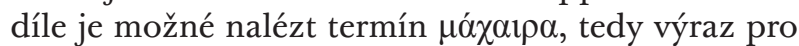
nůž používaný i v jiných kontextech, v Galénových dílech pak litotomický nůž (skolopomachairion) a dlou-

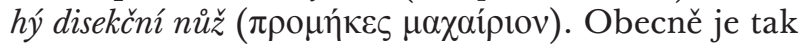
možné přijmout tvrzení, že skalpel, oproti noži, slouží k provádění přesných řezů, je proto vyžadována malá tenká čepel a je tedy celkově menší. Největší $\mathrm{z}$ naprosto neporušených skalpelů $\mathrm{v}$ neapolském muzeu měří 17 cm na délku (Bliquez 2014, 76). Oproti tomu například (porušená) rukojet' v mohučském muzeu měří 16,8 cm bez čepele (Künzl 2002, 27). Nože jsou očekávány větší a s delší čepelí, skalpely měly být malé tak, že bylo vyloučeno běžné užívání ke každodenním účelům. Názvy pro nůž a skalpel ovšem mohly být uživány nejednotně a být zaměňovány (Bliquez 2014, 77).

\subsubsection{Spatula}

Jednostranné či oboustranné nástroje zakončené tupou konkávní stěrkou mohou být označované jako špachtle, sonda, spatula, nebo pátradlo. K. Gostenčnik $(2013,95)$ je řadí mezi sekundární nástroje. $\mathrm{K}$ zařazení mezi chirurgické nástroje je tedy nutné znát nálezový kontext. Importované špachtle jsou často oboustranně použitelné, přičemž jeden konec je často tvarován jako malý knoflík pro broušení různých látek. Jednodušší typy, např. helenistický typ s konkávní stěrkou a s malými křídly, se poměrně často vyskytují již na keltských oppidech. Lžičkové sondy se liší od oválného tvaru až po tvar vrbového listu. Nejsou chronologicky citlivé (Gostenčnik 2002, 168). Ušní sondy/lžičky jsou jednoduché nástroje s kulatou lžičkou nebo zakončením ve tvaru disku (Gostenčnik 2002, 170). Chirurgické lžičky v moderním instrumentáriu slouží k vyškrabávání obsahu v různých prostředích, za tímto účelem je jejich okraj velmi ostrý a nástroj má delší úchopovou část.

\subsubsection{Jehla}

V Corpus Hippocraticum jsou zaznamenány tři př́ipady použití jehel. Jde o propíchnutí otoku kolen při tyfu špičkou trojúhelníkové jehly zvané akis

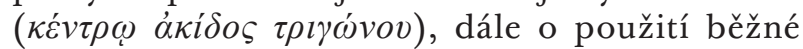
šicí jehly ( $\beta \varepsilon \lambda o ́ v \eta) ~ k$ sešití hemoroidů, aby tkáně po zaškrcení samy odpadly, a ṕpíov, nebo šicí jehla, k propíchnutí pytle před rodičkou naplněného vodou, na který byl umístěn novorozenec po poro- du (resp. před tím, než byla odříznuta pupečníková šňura dítěte). Po propíchnutí pak, jak voda vytékala, byl po klesajícím vaku novorozenec jemně vytažen (Bliquez 2014, 30). Jehly s očkem (šicí) používané v chirurgii jsou popisovány jako ostré a dále jako jemné a velmi jemné, silné, tupé, zahnuté, zahnuté na konci. Jehly s očkem měly řadu účelů a možností užití (Bliquez 2014, 148).

Diskuse o jehlách vyvstala zejména ve spojení s prováděním očních výkonů. Ve spojení s některými bodci či jehlicemi nalézanými mezi artefakty na zkoumaném území (kat. č. 18, 30,31) byla vyslovena hypotéza jejich užití $\mathrm{k}$ očním výkonům. Návrh f. Filka (2004, 33-34) později reviduje T. Zeman (2017, 35). Problematika očních výkonů v historii je však značně komplikovaná a náročnost reklinace i potenciální aspirační metody řešení katarakty vyžaduje nástroje velmi specifických vlastností, kterých diskutované nástroje bud' nedosahují, nebo zcela chybí části artefaktů nutné k doložení těchto předpokladů. Katarakta byla řešena (výkon vyžaduje dislokaci čočky pomocí ostré jehly) pravděpodobně od 2. tis. př. n. 1. (Johns 1904), o extrakci čočky se hovoří od 6. st. př. n. l., uvažuje se rovněž o užití dutých jehel k výkonu aspirace katarakty, a to na základě nálezu sady jehel v Montbellet ve Francii v roce 1975 a duté jehly z Viladamat ve Španělsku v roce 1992 datovaných mezi 1. a 3. st. n. l. (Pérez-Cambrodí et al. 2015, 784). Pro identifikaci podobných artefaktů v našem prostředí je nutné přijmout fakt, že paracentéza oka má potenciál být úspěšná pouze, pokud pracovní část jehly nepřesáhne tloušt'kou 2,2 mm a nepronikne hlouběji než 25,0 mm (vzhledem k sagitálnímu rozměru bulbu).

\subsubsection{Pinzeta}

Pinzety jsou autory zařazovány mezi sekundární nástroje (Gostenčnik 2013, 95). Tento problém rozebral i L. F. Bliquez $(2014,4)$. Došel k názoru, že není vhodné volně směšovat předměty každodenního užívání s chirurgickými, pokud není známý kontext. Objevuje se však termín chirurgická pinzeta, která se od kosmetické liší tvarem. Zde je nutné poznamenat, že z pohledu moderní chirurgie představuje chirurgická pinzeta nástroj, který má na konci funkční části drobné ostré zoubky (na jednom rameni dva, na druhém jeden, vytvář́ tedy jakýsi zámek vhodný k nepohyblivému úchopu tkáně), známé např́iklad na exempláři z 1.-3. st. n. 1. (Weller - Kaiser - Heynowski 2016, obr. 2.2.1.1.).

Nejčastěji se objevují velmi jednoduché pinzety z ohnutého plechu (Gostenčnik 2002, 180). V kontextu sad chirurgických nástrojů jsou však nalézány také dlouhé pinzety s relativně tenkými (i když vždy plochými) rameny a úzkými čelistmi, k preciznímu uchopení tkání. 


\subsubsection{Pila ke kraniotomii}

V kontextu doby laténské jsou nalézány drobné nástroje s rozšířenou funkční částí, jejíž okraj je opatřen malými (původně pravděpodobně ostrými, dnes vlivem oxidačních procesů železa dochováno jen zvlnění) zoubky. Je předpokládáno jejich užívání při perforaci kosti lebeční. Tyto pilky jsou obvykle nazývány trepanační, i přes to, že označovat trepanací provedení otvoru pilkou není zcela přesné. Trȳpanon je totiž označení pro vrták (Kábrt - Kábrt 2004, 934). Kraniotomie se proto jeví jako vhodnější obecnější termín (někteří autoři používají pro pravěkou formu techniky také pojem primitioní kraniotomie; napr. Hobert - Binello 2017).

$\mathrm{V}$ moderní chirurgii ${ }^{1}$ se $\mathrm{k}$ trepanaci kosti přistupuje např. při biopsii v rámci onkologické chirurgie, je-li tkáň nádoru kryta kostí. Je provedena předvrtáním 4 rohových otvorů ve vzdálenosti zhruba 1 centimetru od sebe. Ty jsou spojovány dlátem, nebo trepanovány půlkulatým dlátem o průměru $10 \mathrm{~mm}^{2}$ (Krška - Hoskovec - Petruželka 2014, 658).

\subsubsection{Phlebotom}

Lanceta nebo řezný nástroj označovaný jako $\phi \lambda \varepsilon \beta 0 \tau \dot{0} \mu$ ov neboli phlebotomon se často vyskytuje v textech zabývajících se krvácením. Mezi artefakty jde o vzácný nález, je však možné, že byl v praxi při výkonech nahrazován běžným skalpelem (Bliquez 2014, 7). Phlebotomie je chirurgické protětí žíly (Kábrt - Kábrt 2004, 733), phlebotom však mohl být uživán i při řadě dalších zásahů, např́iklad při odkrývání abscesů, odstranění hydrokély nebo řezání a škrábání při fimóze (Bliquez 2014, 85).

\subsubsection{Jiné „,zdravotnické prostředky“}

Chirurgické instrumentárium zahrnuje nástroje pro diagnostiku a léčbu, $v$ archeologických nálezech se však mohou objevit také další prostředky $\mathrm{k}$ řešení zdravotních obtíží, jako např́ílad protézy a dlahy. Protéza je externě aplikovaná pomůcka, která nahrazuje chybějící nebo nevyvinutou část končetiny, popr. končetinu celou (definice podle ISO 8549). Dlahy jsou prostředky aplikované zevně na část těla sloužící k ochraně, imobilizaci nebo stabilizaci kloubů, korekci a udržení integrity kůže a pohybu

1 V moderní chirurgii jsou užívány pily a vrtačky na elektrický nebo bateriový pohon. Pily mohou být užívány napřs. ke sternotomii při kardiochirurgickém výkonu, odstranění sádrového obvazu, slouží také v patologii. Vrtačky mohou být užity např. v ortopedii, otorinolaryngologii, neurochirurgii (Krška - Hoskovec - Petruželka 2014, 658).

2 Krytí se provádí bud' odklopeným kostním krytem, spongostanem, kostním voskem nebo kostním cementem (Krška Hoskovec-Petruželka 2014, 658).
(Jackman - Lannin - Novak 2014). Pro spojení těchto prostředků s medicínou nebo chirurgií je, stejně jako v př́padě nástrojů popsaných výše, nutné nalézt kontext a oporu v písemných pramenech. Aplikace dlahy nevypovídá o aktivitě lékaře nebo chirurga, tím spíše samostatná protéza.

První informace o ortodontické praxi v dějinách lidstva se týkají Etrusků v 8. až 6. stol. př. n. 1 . (Corruccini - Pacciani 1991, 189). Existují nejméně čtyři exempláře rovnátek sestávající ze zlaté fólie umístěné kolem zubů sousedících se ztraceným zubem. Znalosti byly zřejmě v omezené míře předány Ř́manům. Tyto zlaté proužky byly použity k postupnému uzavírání prostoru zanechaného zubem ztraceným za života. Většina ostatních pomůcek se místo toho používala k držení falešných zubů, téměř vždy na místě předních zubů, špičáků a řezáků, jejichž absenci lze snadněji zjistit (Corruccini - Pacciani 1991, 189). Zubní protéza z nekropole v Ř́mě pocházející z 1.-2. st. n. l. poskytuje důkaz o užívání tohoto prostředku v době císařství. Ačkoli mnoho římských literárních zdrojů dokumentuje vývoj stomatologie během císařského věku, Aulus Cornelius Celsus (25 př̀ n. 1.-50 n. 1.) ve spise De Medicina (svazek 7, XII) uvádí, že pokud jsou kvůli úrazu nebo z jiných důvodů některé zuby nestabilní, musí být svázány s pevnými zuby zlatým drátem (Minozzi et al. 2007, e1).

Diskutován je rovněž význam mandibulární masky z pohřbu staré ženy z Kampánie, někteří badatelé se domnívají, že představovala ochrannou pomůcku pro lékařské účely (Balassone et al. 2018).

\section{Rozbor artefaktů}

Následuje rozbor artefaktů interpretovaných badateli jako „lékařské" nebo chirurgické nástroje nalezených na území dnešní ČR, SR a naddunajské části Dolního Rakouska. Jednotlivé artefakty jsou rozřazeny $\mathrm{v}$ katalogu podle určení jejich původu $\mathrm{v}$ době železné nebo $\mathrm{v}$ době římské, na základě názorů badatelů na konkrétní artefakty. Artefakty jsou v rámci období seřazeny abecedně podle lokality nálezu a je jim přiřazeno pořadové číslo pouze pro účely katalogu uvedeného jako př́loha tohoto článku.

Zařazení artefaktů $\mathrm{v}$ katalogu mezi importy a předměty místní výroby, stejně jako jejich názvy/ označení v katalogu, odpovídají doposud akceptovaným interpretacím. Př́padné návrhy na reevaluaci interpretací jsou prezentovány a obhajovány $\mathrm{v}$ rámci rozborů artefaktů $\mathrm{v}$ této kapitole. $\mathrm{V}$ katalogu (v textu používána zkratka „kat.“) je pro výsledek kritického přehodnocení vyhrazeno pole „Návrh interpretace“. 


\subsection{Artefakty doby halštatské a laténské}

Nástroje považované za importované ve sledovaném souboru (kat. č. 2, 6, 9, 10, 11, 12) jsou datovány od LT B2 (kat. č. 2), spatuly jsou datovány od LT C2 do LT D2. Předpokládaná pila z Býčí skály by pak měla pocházet z doby halštatské.

\subsubsection{Spatula/sonda}

Se spatulami souvisí tradiční otázka archeologie medicíny, tedy spojení jednotlivých artefaktů s organizovaným oborem, oproti artefaktům užívaným širokou veřejností např. k osobní hygieně. K. Gostenčnik $(2013,95)$ řadí spatuly k sekundárním nástrojům. Pro přiřazení sekundárních nástrojů k činnostem oboru je nutné vycházet z nálezových kontextů artefaktů. Helénistický typ sond s konkávní zapuštěnou špachtlí a některé s malými „křídly“ (např. z Magdalensbergu; obr. 1: 6) se relativně často vyskytují v prostředí laténských oppid (Gostenčnik 2002, 168). Velmi plochý dř́́k lze pozorovat na artefaktech z laténských sídlišt' např. z Jüchsen (Grasselt 1994) v Durynsku (obr. 1: 7) a Basel-Gasfabrik ve Švýcarsku (obr. 1: 8). Tomuto popisu odpovídají i artefakty nalezené v Oberleiserbergu (obr. 1: 1; kat. ̌́. 6) a Stradonicích (obr. 1: 3, 4; kat. č. 10 a 11). Spatula s hladkým zaobleným dř́kem (obr. 1: 2; kat. ̌́. 9) se od této podoby odlišuje. Sondy s méně zdobeným přechodem spatuly a dř́ku, a rovněž delší, jsou známy např́klad ze sady nástrojů nalezených na území dnešního Kapidaghi v Turecku až v období od 1. do počátku 2. st. n. 1. (obr. 1: 5). Spatuly na keltských oppidech jsou pravděpodobně importované (Gostenčnik 2002, 168). Podle K. Gostenčnik (2013, 95) samotná spatula nedokládá př́ítomnost specialisty lékaře či chirurga, ve Stradonicích je ale možné interpretovat několik dalších nástrojů vhodných k léčebným výkonům. Nálezy z Oberleiserbergu i Stradonic jsou analogické k římským, mírná tvarová odlišnost je pozorována u artefaktu ze Stradonic (obr. 1: 2).

Tři železné fragmenty nástrojů z Hrazan (kat. č. 5) nedovolují přesné vysvětlení účelu. Vzhledem ke tvaru a provedení je vhodné uvažovat o místní výrobě artefaktů. Železné šídlo nebo bodec s kulatou hřídelí a čtvercovým trnem (kat. ̌́. 5: c) mohlo být využíváno při zpracování kůže, pro užití jako sondy se jeví pracovní část nástroje příliš krátká. Drobný nástroj s koncem ve tvaru špachtle (kat. $\check{c} .5:$ b) nelze kvůli tvaru pracovní části a hranatému dř́ku srovnávat s importovanými artefakty, nástroj s širokým asymetrickým zakončením ve tvaru špachtle (kat. č. 5: a) může být fragmentem zcela jiného předmětu. Ze zkoumaného souboru je možné za spatuly označit pouze artefakty ze Stradonic a Oberleiserbergu.

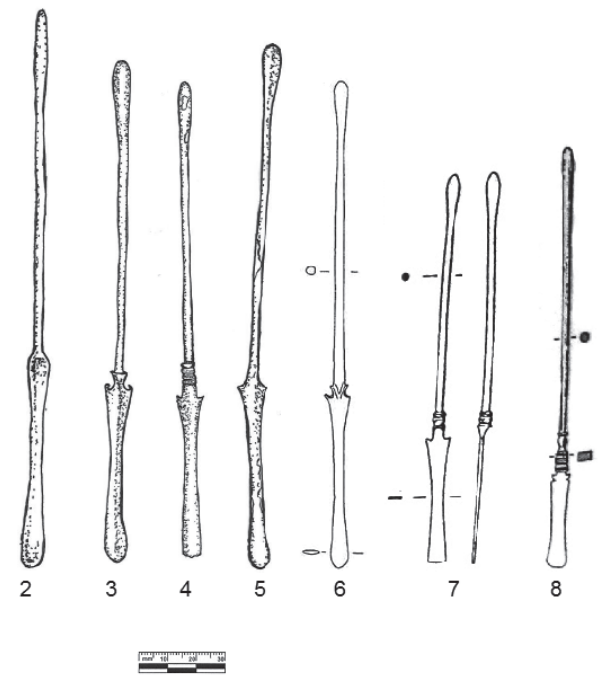

Obr. 1. Přehled artefaktů interpretovaných jako spatula. 1: Spatula, Oberleiserberg, upraveno podle Kern (1996, Abb. 8), neznámá velikost; 2: spatula, Stradonice, inv. č. 81459 (kresba podle Databáze archeologické sbirky v.4.2); 3: spatula, Stradonice, inv. č. 81460 (kresba podle Databáze archeologické sbírky v.4.2); 4: spatula, Stradonice, inv. č. 81461 (kresba podle Databáze archeologické sbirky v.4.2); 5: spatula ze sady nástrojů nalezených na území dnešního Kapidaghi v Turecku z 1. až počátku 2. st. n. l. (kresba podle Bliquez 2014, 433); 6: Magdalensberg, Korutany, Rakousko (Gostenčnik 2002, Abb. 3:4); 7: z laténského sídliště Jüchsen v Durynsku, Německo (Künzl 1995, Fig. 8); 8: z laténského sídlišstě Basel-Gasfabrik, Švýcarsko (Künzl 1995, Fig. 7). - Fig. 1. An overview of the artefacts interpreted as spatulae. 1: Spatula, Oberleiserberg, adapted after Kern (1996, Abb. 8), unknown size; 2: spatula, Stradonice, inv. Nr. 81459 (drawing after the Database of the Archaeological Collection/Databáze archeologické sbirky v.4.2); 3: spatula, Stradonice, inv. Nr. 81460 (drawing after the Database of the Archaeological Collection/Databáze archeologické sbirky v.4.2); 4: spatula, Stradonice, inv. Nr. 81461 (drawing after the Database of the Archaeological Collection/Databáze archeologické sbirky v.4.2); 5: spatula from the set of instruments found on the territory of today's Kapidaghi in Turkey from the 1st to the beginning of the 2nd centuries AD (drawing after Bliquez 2014, 433); 6: Magdalensberg, Carinthia, Austria (Gostenčnik 2002, Abb. 3:4); 7: from the La Tène settlement of Jüchsen in Thuringia, Germany (Künzl 1995, Fig. 8); 8: from the La Tène settlement of Basel-Gasfabrik, Switzerland (Künzl 1995, Fig. 7).

\subsubsection{Phlebotom}

Phlebotom interpretovaný J. L. Píčem mezi nálezy z oppida ve Stradonicích (obr. 2: 1; kat. č. 12) má velmi výrazné ztvárnění. Tvar nástroje odpovídá potřebám phlebotomu, ostrý, ale záhy se rozšiřující hrot umožňuje perforovat tkáně, aniž by se otvor př́liš rychle zceloval.

Nástroj je podle kontextu naleziště datován do pozdního stupně doby laténské (Píč 1903, 69). Podobný tvar phlebotomu je ale možné sledovat 
i v následujících obdobích, kde jsou známy z rozsáhlých souborů chirurgického instrumentária. Zajímavou analogii poskytuje phlebotom z výzkumů měst zničených Vesuvem (obr. 2: 3), artefakt pocházející z Itálie z 1. až počátku 2. st. n. 1. (obr. 2: 4) nebo rekonstrukce podoby phlebotomu z 1 . poloviny 3. st. n. 1. (obr. 2: 2). Tvar je známý i z medicíny 19. století (obr. 2: 5). Funkci phlebotomu mohl zastávat také další artefakt ze Stradonic (obr. 2: 6). Phlebotom lze považovat za primární nástroj dle rozdělení podle Korduly Gostenčnik $(2013,95)$ a napovídá tedy př́tomnosti osob cíleně vykonávajících léčebné výkony.

Návrh f. L. Píče (1903, 69) na užití nástroje ze Stradonic k léčebným výkonům další autoři nepotvrzují (neobjevují se žádné zmínky o phlebotomu/ lancetě v pracích zabývajících se nástroji ze Stradonic). Artefakt však morfologicky odpovídá phlebotomům z následujících období, prakticky až do novověku.

\subsubsection{Kleště}

Kontext hrobu umožnil autorům výzkumu z roku 2010 v Bašti (Pecinovská - Baloun - Sankot 2014) datovat drátěný předmět (Kat č. 2) neznámého účelu (obr. 3: 1) do období LT B2 a vyloučit účel užívání jako součásti opasku. Nepotvrzená zůstává hypotéza pérových kleští pro užití ve spojení s kovářskými činnostmi a výrobou skleněných náramků. Autoři zvažují rovněž podobnost se součástmi takzvaných toaletních souprav (Pecinovská - Baloun - Sankot 2014). Jde o železný předmět tvořený ohnutým drátem s otiskem kůže ve středové části a dvojicí kuliček o průměru 4 mm na konci každého z ramen (Kučerová 2012, 13).

K posouzení tvarové podobnosti s pinzetami a kleštěmi ze souborů chirurgických instrumentů slouží artefakt z Pompejí (obr. 3: 2) a dále artefakty uložené v muzeích v Mohuči (obr. 3: 3) a Athénách (obr. 3: 4).

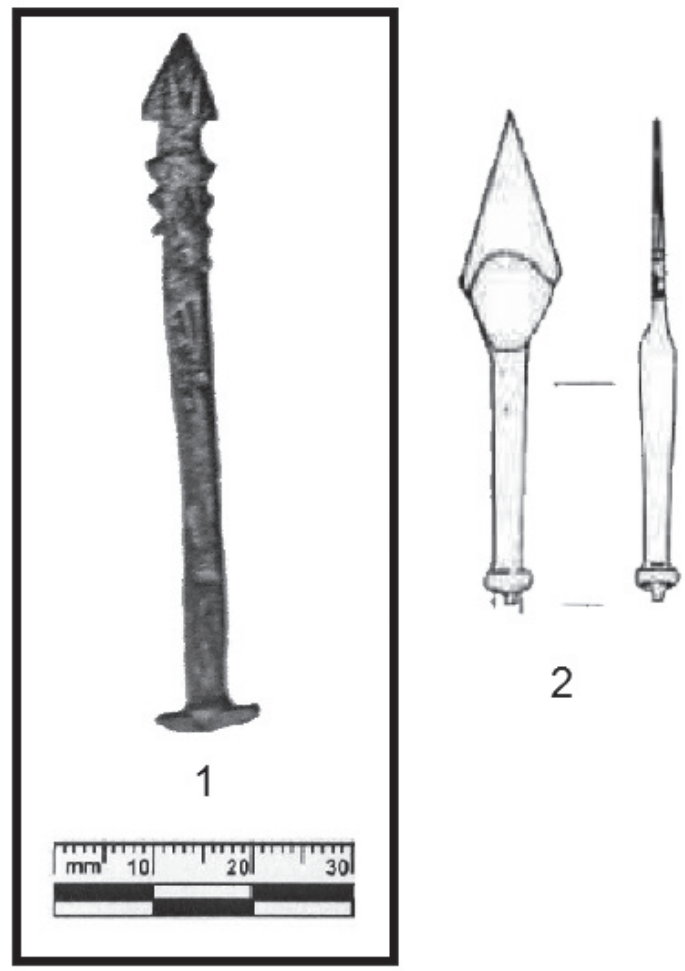

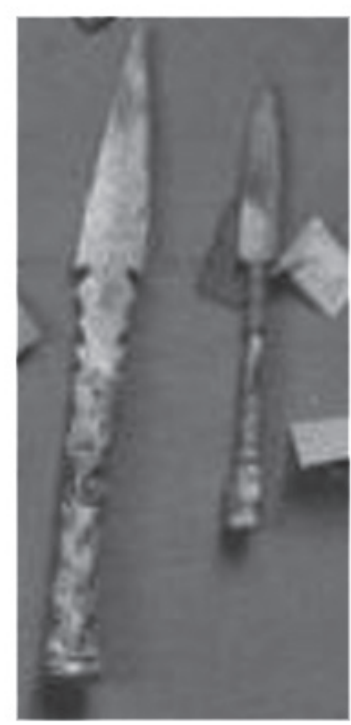

3
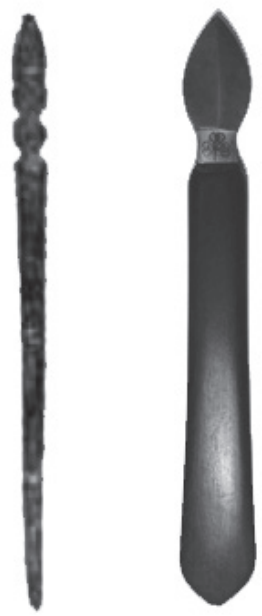

5

4

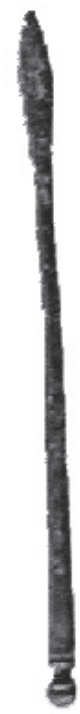

Obr. 2. Phlebotom (2-6 bez měřítka). 1: Stradonice (Píc 1903, Tab. XXIV:12); 2: Rekonstrukce podoby phlebotomu z 1. poloviny 3. století n. l. (Gostenčnik 2004, Abb. 5:1); 3: Phlebotomy z výzkumů měst zničených Vesuvem uložené v Museo Archeologico Nazionale di Napoli (Bliquez 2014, Fig. 2); 4: Artefakt pocházející z Itálie z 1. až počátku 2. století n. l. umístěný v The British Museum (Bliquez 2014, Fig. 3); 5: Phlebotom z 19. století z vlastní sbírky prof. L. A. Parapia (2008, Fig. 7); 6: Stradonice (Píc 1903, Tab. XXIV:25). - Fig. 2. Phlebotom (2-6 without a scale). 1: Stradonice (Píc 1903, Tab. XXIV:12); 2: Reconstruction of the appearance of a phlebotomy from the first half of the 3rd century (Gostenčnik 2004, Abb. 5:1); 3: Phlebotoms from the researches of the cities destroyed by Vesuvius deposited in the Museo Archeologico Nazionale di Napoli (Bliquez 2014, Fig. 2); 4: Artefact coming from Italy from the 1st to the beginning of the 2nd centuries AD located in The British Museum (Bliquez 2014, Fig. 3); 5: Phlebotom from the 19th century from the personal collection of Prof. L. A. Parapia (2008, Fig. 7); 6: Stradonice (Píc 1903, Tab. XXIV:25). 


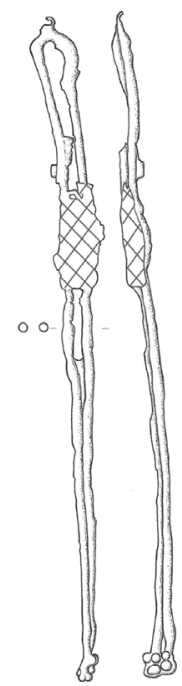

1

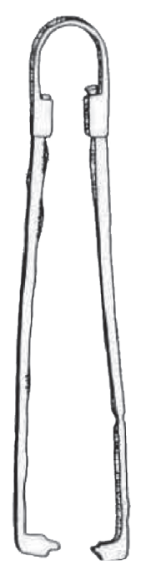

2

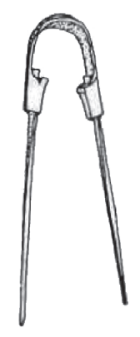

3

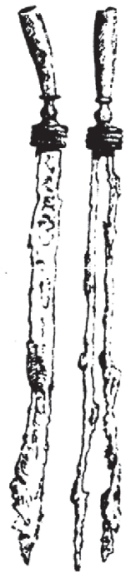

4

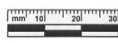

Obr. 3. Pinzety a kleště. 1: Bašt' (Pecinorská - Baloun - Sankot 2014); 2: Pompeje (Gostenčnik 2004, Abb. 10:2); 3: RGZM Mainz (Gostenčnik 2004, Abb. 10:3); 4: Národní archeologické muzeum v Athénách (Bliquez 2014, Fig. 33). - Fig. 3. Tweezers and forceps. 1: Bašt' (Pecinorská - Baloun - Sankot 2014); 2: Pompeii (Gostenčnik 2004, Abb. 10:2); 3: RGZM Mainz (Gostenčnik 2004, Abb. 10:3); 4: National Archaeological Museum in Athens (Bliquez 2014, Fig. 33).

Pro zkoumané kleště není předložena dostatečně přesná analogie, i přes to, že pinzety a kleště patří mezi artefakty k relativně hojně se vyskytujícím. Posuzovaný artefakt se vyznačuje několika problematickými vlastnostmi. Ramena předpokládaných kleští jsou velmi tenká (síla $2 \mathrm{~mm}$ ) a nabývají kruhového průřezu. Nejčastěji je možné se setkat s plochými rameny $\mathrm{v}$ podobě, $\mathrm{v}$ jaké jsou vidět na artefaktu $\mathrm{z}$ athénského muzea (obr. 3: 4). Artefakt z Mohuče reprezentuje pinzety s tenkými rameny, jejich předpokládaná křehkost a pružnost však zjevně vedla k tomu, že nástroj musel být konstruován pouze drobný a krátký. Kruhový průřez ramen také znesnadňuje úchop objektu kleštěmi.

O účelu artefaktu jako kleští, či pinzety může být uvažováno, jmenované nevýhody však činí nástroj nepraktickým. Nelze potvrdit účel k léčebným výkonům. Další artefakty nalezené v hrobě situaci rovněž nevyjasňují, nebyl nalezen žádný předmět, který by mohl sloužit k léčebným výkonům.

\subsubsection{Skalpel}

Jako skalpely byly interpretovány dva artefakty z oppida Tŕísov (kat. č. 13 a 14). Plochý zahnutý artefakt s čepelí na obou koncích (kat. č. 13) nejeví známky, že by na něj mohla být někde napojena rukojet', např. z rychle degradujícího materiálu. Předmět by tedy jako skalpel nebylo snadné použít, nemá totiž žádnou vyhovující pomocnou/úchopovou část. Předmět listovitého tvaru z bronzového drátu (kat. c. 14) je velmi drobný a jeho hráněný trn byl pravděpodobně určen k zasazení do rukojeti. Malá velikost by odpovídala požadavku skalpelu, ale nejeví známky, že pracovní část musela být zbroušena do čepele. Není proto možné vyloučit použití jako sekundárního nástroje, např. špachtle, funkci skalpelu ale není možné doložit.

\subsubsection{Soubory nástrojů}

Sada železných nástrojů (kat. č. 7) z doby laténské byla nalezena ve Slatině nad Bebravou v roce 2008. K. Pieta tento soubor následně interpretoval jako sadu nástrojů určených pro chirurgickou léčbu (Pieta 2008, 112). Šlo o detektorový nález artefaktů datovaných podle významného hradiště z doby laténské (ovšem některé části opevnění nalezených na lokalitě mohou být i raně nebo pozdně středověké, proto je možné uvažovat i o tom, že sada pochází ze středověku). Artefakty ze Slatiny nad Bebravou (např́lklad na obr. 4: 1 a 2) mají trny určené $\mathrm{k}$ nasazení na rukojet' ze snadno degradujícího materiálu ve shodném tvaru a délce s nástroji známými z jiných souborů nalezených v Evropě (reprezentuje obr. 4: 3), také přechod do pracovní části nástroje je obvykle opatřen ozdobným rozširrením. V souboru mohou být př́tomny sondy (kat. č. 7: a, b, c, e), skalpel (kat. ̌́. 7: a) a pila ke kraniotomiím (kat. č. 7: f), která bude diskutována v následující kapitole. Bylo zvažováno také užití nástrojů ke zpracování kůže, které nemůže být s jistotou vyloučeno. Př́tomnost nástroje značně se podobajícího pilám ke kraniotomiím a provedení artefaktů analogické k evropským souborům naznačuje, že soubor mohl skutečně sloužit $\mathrm{k}$ léčebným výkonům. Je však nezbytné připomenout, že při výrobě obuvi se využívá také tzv. sedlářský půlměsíc, který je vhodný pro dlouhé řezy a silné kůže. Protože artefakt tvaru pily ke kraniotomiím (kat. č. 7: f), není dochován (pouze na fotografii) a nebylo tedy možné důkladněji prozkoumat potenciální „pilovité ostř́i“, mohlo se jednat také o nástroj k výrobě obuvi nebo obecněji zpracování kůží podobný modernímu sedlářskému půlměsícovitému noži. Sada nástrojů ze Slatiny nad Bebravou, interpretovaných Karolem Pietou jako pravděpodobně používaných $\mathrm{k}$ léčbě v době laténské (Pieta 2008, 112), skutečně mohla sloužit $\mathrm{k}$ tomuto účelu ${ }^{3}$. Artefakty jsou tvarem i zpracováním velmi vhodné k perforaci tkání4 . Svým složením je

3 Za aktuálního stavu prozkoumání je nutné připustit i alternativní hypotézu, že mohlo jít o řemeslnickou sadu pro jinou činnost.

4 Zde je zřejmá kolize např. s účelem při zpracování kůže, výrobě obuvi. 
sada vhodnou náhradou za chirurgické sady známé $\mathrm{z}$ římského prostředín ${ }^{5}$, technické provedení je ovšem typické pro místní výrobu a odporuje kvalitě i materiálu používanému Rímany.

Artefakt ze Stradonic hodnocený v rámci souboru artefaktů (kat. č. 8: d) má shodný tvar se šicími jehlami známými např. z Manchingu (Jacobi 1974, Taf. 26: 451-458), u nichž je rovněž obvyklé odlomení v křehkém místě otvoru. Nožík (kat. č. 8: a) a dva tyčinkovité nástroje (kat. č. 8: b, c) mohly sloužit k léčebným výkonům stejně tak, jako k práci $\mathrm{s}$ kůží, např́íklad k výrobě obuvi. U souboru existují pochybnosti o dataci i místě nálezu.

\subsubsection{Pily ke kraniotomiím}

Nejstarším nálezem v katalogu ve tvaru pil ke kraniotomiím je artefakt s předpokládanou pracovní částí zakončenou pilovitým ostřím z Býčí skály (obr. 4: 9; kat. č. 1). Kontext nálezu, tedy především přítomnost lebek s nerovnými a světlými řezy oproti zbytku kosti (tedy zřejmě posmrtně provedenými), ale také např. nález lebky se zhojeným otvorem o rozměru $10 \times 15$ mm se zoubkovaným okrajem, který Wankel interpretoval jako zhojený otvor po provedené kraniotomii, vypovídají o možnosti, že pily se na lokalitě používaly. Ačkoliv, jak upozorňuje $K$. Stloukal (1981, 113), protože byl otvor v době smrti zcelen, nemusí mít s nálezovým kontextem lebky souvislost. Může ale podpořit hypotézu, že se výkony pomocí nástroje tohoto typu v dosahu lokality prováděly (Stloukal 1981, 112-113). O užití tohoto nástroje ke kraniotomii uvažuje i Petra Härtl (2005). Není zcela jasné, zda artefakt skutečně pochází z doby halštatské. Tvarem se podobá artefaktu, který prezentuje např. A. Kern (1996, Fig. 3: a) z Mnichova-Obermenzingu, ten má ovšem pocházet až z období LT C. Kontakty s antickými společnostmi pravděpodobně existovaly již od doby halštatské a řada artefaktů z jeskyně Býčí skála je považována za importy (doba halštatská Golec 2015, 125; doba římská Golec 2017, 56), což podporuje také dříve uvedenou domněnku, že znalost perforace lebeční kosti pomocí pily mohla být získána např́klad ze starověkého Řecka. Paradoxně ale hippokratovské spisy nepopisují nástroje na kraniotomie dostatečně přesně. Uvádějí ale, že pracovní část nástroje byla opatřena zoubkováním. Někteří autoři proto předpokládají, že se mohlo jednat o nástroj označovaný jako modiolus (Ganz 2017, obr. 3.4; Tullo 2010; Künzl 1983, 5-6), tedy dutý tyčinkovitý nástroj se středovým kolíkem, jehož pracovní část je tvořena dutým válcem se zoubkovitým ostřím po obvodu kruhu. Rukojet' měla být točena mezi dla-

5 Dále také postrádá některé součásti očekávané v sadě vhodné pro výrobu obuvi. němi, Ganz ovšem nedokáže vysvětlit, jakým způsobem byla aplikována síla směrem dolů. Středový kolík má stabilizovat nástroj, dokud nevznikne kruhová drážka v kosti, pak je odstraněn (Ganz 2017, 23-54). Je však možné předpokládat, že i přes tvrdost lebeční kosti není nutné na pilu klást značný tlak. Zoubky by i při nízkém tlaku měly nabírat řezaný materiál relativně snadno. Tak jako při řezání jiných materiálů by př́lišný tlak způsoboval obstrukce pilovitého ostří. Přiměřený tlak by mohl být zajištěn asistující osobou.

Rozšířená pracovní část nástroje (obr. 4: 4; kat. č. 7: f1 a f2) ze Slatiny nad Bebravou vykazuje některé shodné prvky s pilou ze souboru z hrobu z Batiny (obr. 4: 5). Zahnutý krček směřující od úchopové části k pracovní (u nástroje z Batiny) je prvkem k usnadnění práce s nástrojem, ale u zkoumaného nástroje je krček rovný. Tvar kalvy vedl k nutnosti odsadit pracovní část pily od úchopové, čehož může být dosaženo např. právě zahnutím krčku trepanačních pil, které dobře vyobrazují chirurgické př́ručky z 18.19. století. Řada z vyobrazených nástrojů z novověku (např. Heisters 1724, Tab. III: 8-15) je téměř totožná s některými artefakty, které mají pocházet z doby laténské, jak je interpretuje E. Künzl (1995). Stejně tak jsou ale až do novověku využívány pily nezahnuté (např. Fritze 1843, Taf. II). Zahnutí pily souvisí s polohou operované osoby a operujícího a lokací výkonu na kalvě. Zahnutí také mění rozložení síly vyvíjené operujícím a klade větší nároky na kvalitu materiálu nástroje. Méně ostrou zahnutou pilu z měkčího materiálu bude fyzicky náročnější použít. Artefakt ze Stradonic (obr. 4: 6; Píc 1903, Tab. XXIV: 13) byl dř́ve srovnáván (Pieta 2008, 203) s uvažovanou pilou ze Slatiny nad Bebravou (obr. 4: 4; kat. č. 7 : f1 a f2). V případě tohoto porovnání je však nutné zvážit, že ačkoliv Bliquez (2014, 385, Fig. 3) zachytil podobné artefakty v souborech z Itálie 1 . až počátku 2. st. n. 1. (obr. 4: 7), např. G. R. Davidson (1952) podobné korintské artefakty (obr. 4: 8) interpretoval jako stily (Davidson 1952, Plate 83: 1351), což se jeví velmi nepravděpodobné.

Problém nediskutovaný v tomto textu, ale související s problematikou pil určených $\mathrm{k}$ operacím na tvrdých tkáních, představuje také artefakt z Pottenbrunnu v Rakousku (obr. 4: 10). V díle P. Ramsla (2002, 91) byla navržena hypotéza určení tohoto artefaktu z předoppidálního období jako „skalpelové pilky“. Provádění operačního výkonu s takovýmto nástrojem se však jeví značně problematické. K řezání tvrdých tkání by nástroj nebylo snadné použít, nemá totiž žádnou pomocnou/úchopovou část, ani nejeví známky, že by mohla být někde napojena rukojet' např. z rychle degradujícího materiálu (ačkoliv by teoreticky pilka mohla fungovat, kdyby byla zasazena do mechanismu obdobného dnešním pilkám na železo). Držení pouze za hranu/týl nástroje 


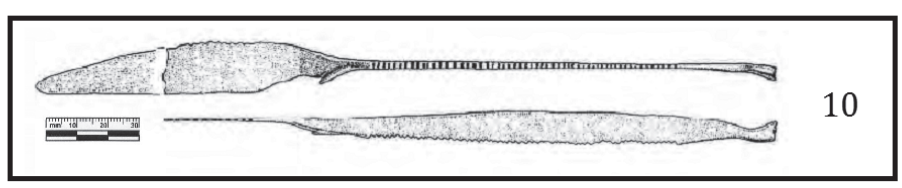

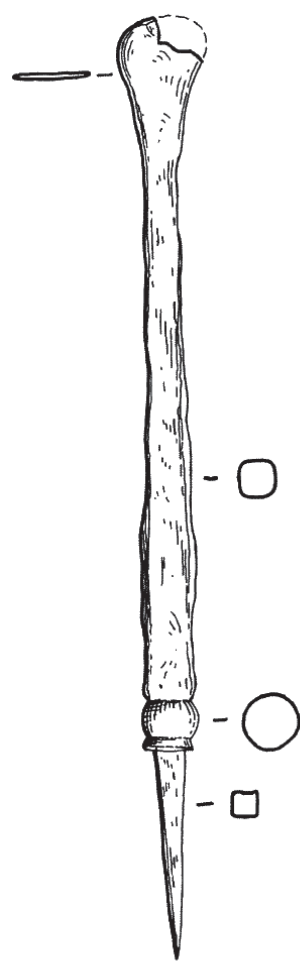

1

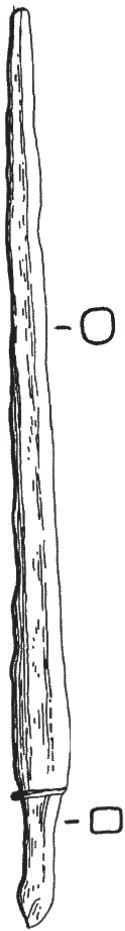

2

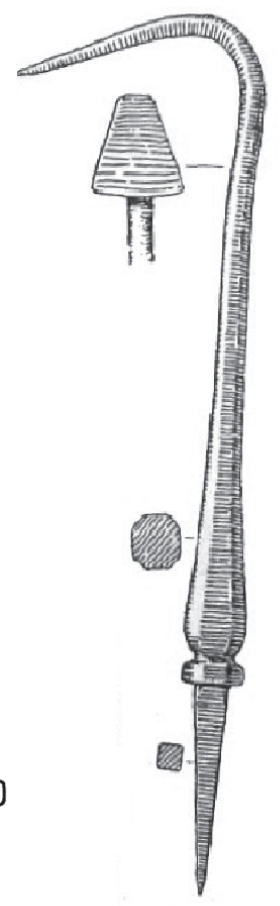

3
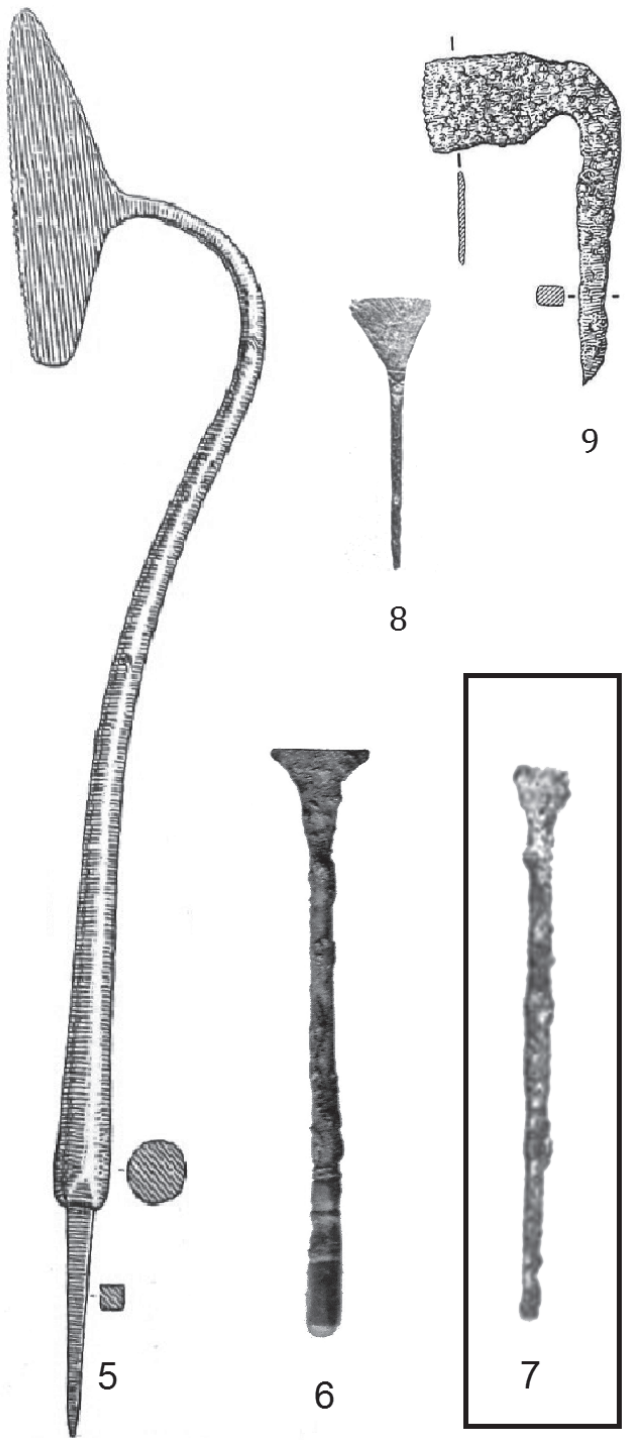

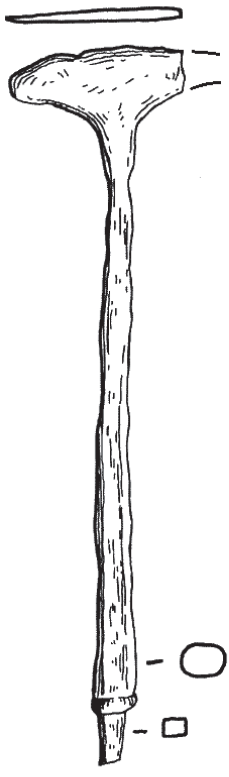

4

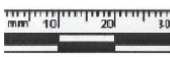

Obr. 4. Artefakty 1, 2, 4 z hromadného nálezu ve Slatině nad Bebravou (kresby K. Pieta); artefakty 3 (Künzl 1995, Fig. 4:e) a 5 (Künzl 1995, Fig. 4:d) pocházejí ze souboru z hrobu z Batiny v chorvatském regionu Baranja (artefakt 5 byl interpretován jako pila na trepanaci); artefakt 6 (Ṕč 1903, Tab. XXIV:13) byl srovnáván (Pieta 2008, 203) s předmětem 4; artefakt 7 pochází z Itálie 1. až počátku 2. st. n. l. (Bliquez 2014, 385, Fig. 3; neznámé měřítko); 8: stilus (Davidson 1952, Plate 83: 1351); 9: artefakt z Býćí skály; 10: „Skalpelová pilka“ z Pottenbrunnu, samostatné měřítko (Ramsl 2002, Taf. 60: 8). - Fig. 4. Artefacts 1, 2, 4 from a mass find in Slatina nad Bebravou (drawing by K. Pieta); artefacts 3 (Künzl 1995, Fig. 4:e) and 5 (Künzl 1995, Fig. 4:d) come from a set from the grave from Batina in the Croatian region of Baranja (artefact 5 has been interpreted as a trepanation saw); artefact 6 (Píc 1903, Tab. XXIV:13) has been compared (Pieta 2008, 203) with item 4; artefact 7 comes from Italy in the 1st to beginning of the 2nd centuries AD (Bliquez 2014, 385, Fig. 3; unknown scale); 8 : stylus (Davidson 1952, Plate 83: 1351); 9: artefact from Bull Rock Cave; 10: "Scalpel saw" from Pottenbrunn, independent scale (Ramsl 2002, Taf. 60: 8).

by pravděpodobně nestačilo k řezání nebo perforování kostí, měkké tkáně by naopak pila trhala, což by zpo̊sobilo infekce a zpomalovalo hojení operační rány. Ani jedno z pilovitých ostř́i se svou lokací nejeví vhodné k perforaci lebečních kostí.

\subsubsection{Dlátka}

Dlátka není možné bez dalších artefaktů podporujících tuto hypotézu označovat za nástroje k léčebným výkonům. Dlátka mohou být používána k opracování dřeva, jako rydla a v dalších kontextech. Bronzové dlátko z domu 13/61 v Hrazanech (kat.č. 3) nalezené v kombinaci s hřebíkem není možné považovat za nástroj k léčebným výkonům. Není zřejmé, jakým způsobem by byl takový nástroj používán, protože chybí známky napojení do úchopové části. Teorie dlátka na operace kostí se jeví velmi nepravděpodobná. Uvažované analogie (Jansová 1992) z Manchingu rovněž neumož- 
ňují jistou identifikaci předmětu jako „kostního sekáče".

Železné „dlátko“ z Hrazan (kat. č. 4) je značně narušeno korozí. V domě 13/61 byl artefakt nalezen společně s jehlicí z doby bronzové. Pokud se skutečně jednalo o dlátko, mohlo být užíváno v širokém spektru kontextů. Podle G. Jacobiho (1974, 35-36) patří železná dláta mezi jedny z nejčastějších řemeslných nástrojů nalézaných na oppidech a používala se, ačkoliv mohla sloužit při léčebných zásazích nebo při kovářství, zejména při řezbářských pracích.

\subsection{Artefakty doby římské}

Mezi artefakty doby římské jsou zastoupeny zejména nože a břitvy, u nichž je přiřazení $\mathrm{k}$ chirurgickému instrumentáriu značně diskutabilní, dále sondy s analogiemi v souborech zahrnujících primární i sekundární nástroje a jehlicovité bodce, u nichž je blíže zkoumán možný skutečný účel.

\subsubsection{Spatula/sonda}

Fragmenty tyčinkovitých předmětů z Bratislavy-Dúbravky (kat. č. 19 a 20) mohou být zlomky spatul, ale kvůli stavu dochování je rozhodnutí velmi problematické. Jeden z nich je získán sběrem (kat. č. 19), druhý z polozemnice (kat. č. 20), ve které byly nalezeny také jiné drobné kovové artefakty nebo jejich zlomky. Z lokality nepocházejí jiné artefakty, které by bylo možné označit za primární nástroje, o těchto dvou zlomcích je tedy možné uvažovat pouze jako o sekundárních nástrojích. Spatula z Malacek (kat. č. 29) byla získána povrchovým sběrem, morfologicky odpovídá importovaným spatulám z 1.-4. st. n. 1. Sonda ze Sekulí (kat. č. 39) zakončená olivkou byla díky dalším artefaktům z hrobu 40/2017 přesněji datována do 2. pol. 2. st. n. l. Kvůli kontextu byl sondě přisouzen účel pro kosmetické činnosti.

Analýza Katherine E. Jakielski a Michaela R. Notise (2000) dokládá, že sondy (zkoumána byla ušní sonda) mohou být vyrobeny jako jeden nedělený kus, přičemž je možné zaznamenat také relativně konstantní vrstvu patiny. U jiného artefaktu (zkoumané spatuly) však zachytili také konstrukci ze dvou dílů, tedy úchopové části, do níž byla zasazena část pracovní (Jakielski - Notis 2000). U artefaktu z Bratislavy-Dúbravky nelze určit, zda se jednalo o jeden kus, či dělený předmět (kat. č. 19 a 20), artefakt z Malacek se jeví jako nedělený (kat. č. 29), artefakt ze Sekulí ale nebyl exaktně analyzován k posouzení potenciálního spoje (kat. č. 39), tedy hráněné zesílené části mezi oběma stranami sondy.

\subsubsection{Nože a skalpely}

V souboru artefaktů interpretovaných jako nože a skalpely určené k chirurgickým zákrokům je značné množství artefaktů, které morfologicky odpovídají břitvám na holení. Ze zjištění E. Droberjara (2006, 643) vyplývá, že v žárových hrobech stupně B1 v Čechách se nože těchto tvarů vyskytují hojně a považuje je za břitvy. No̊ž ze Zlivi (kat. ̌̌. 48) je srovnáván (Droberjar 2006, 642; Kolník 2004) s nožem z Poggendorfu (Eggers 1932, Abb. 4) z 1. st. n. 1., nepochybně jde o analogii a ostatní artefakty v hrobech potvrzují, že nůž může být importovaný z Římské říše. Římské bronzové pánve, kovové zrcadlo, nůžky, nůž, jehly a kování picích rohů v hrobech však nevedou $\mathrm{k}$ závěru, že nůž měl být primárně určen pro provádění léčebných zákroků. Mezi známými soubory chirurgických nástrojů se podobné nože nevyskytují.

Srpovité nože, resp. srpovité břitvy, avšak interpretované jako chirurgické nože, v katalogu zastupují artefakty z Abrahámu (kat. č. 16), Altenmarkt im Thale (kat. ̌́. 17), Břeclavi (kat. ̌́. 21), Dobřichova-Pičhory (kat. č. 24: b, c), Lábu (kat. č. 28), Pederu (kat. ̌́. 37), Stehelčevsi (kat. č. 40: b, c) a Zohoru (kat. c. 49). Obdobně je tomu u nožovité břitvy z Eggendorfu (kat. ̌́. 26) a Dobřichova-Pičhory (kat. ̌́. 24: a). Nůž z Ohništan (kat. č. 36) je v žárovém hrobě doprovázen půlměsícovitou břitvou a nůžkami, soupravou cedníku a naběračky a pravděpodobně tedy patřil k osobnímu vybavení jedince. Podobně je možné posuzovat nůž z hrobu ve Stehelčevsi (kat. č. 40: a), který je tvarem velmi podobný artefaktu z Ohništan a rovněž je doprovázen dalšími osobními předměty. Obr. 5 představuje typickou půlměsícovitou břitvu (obr. 5: 1), obloukovitý nůž (obr. 5: 2) a malý nůž s prstencovitým zakončením úchopové části (obr. 5: 3), který byl interpretován jako chirurgický. Nůž s prstencovým zakončením pochází z hrobu s prrítomností dalšího předpokládaného instrumentária, který byl označen za „hrob lékaře“. Nůž má odpovídat době laténské. Břitvu i obloukovitý nůž zařadili autoři mezi kosmetické nástroje (Weller - Kaiser - Heynowski 2016, 132). Nože a břitvy s očkem (např. kat. č. 16) vykazují jiná tvarová specifika než nůž s prstencovým zakončením (obr. 5: 3).

Rovné nože s plnou rukojetí mezi sledovanými artefakty není možné označit za skalpely, ve známých souborech nejsou analogie a nálezový kontext této domněnce neodpovídá. Nůž z Abrahámu (kat. č. 15), nůž z Dobřichova-Pičhory (kat. č. 23) a nůž s koncovým kroužkem z Velatic (kat. č. 46) mohl sloužit $\mathrm{k}$ rozličným účelům, užití k chirurgickým výkonům není odůvodněné. Nůž z Kostelce na Hané (kat. č. 27) má analogie v Polsku (Kolník 2004, 168), 


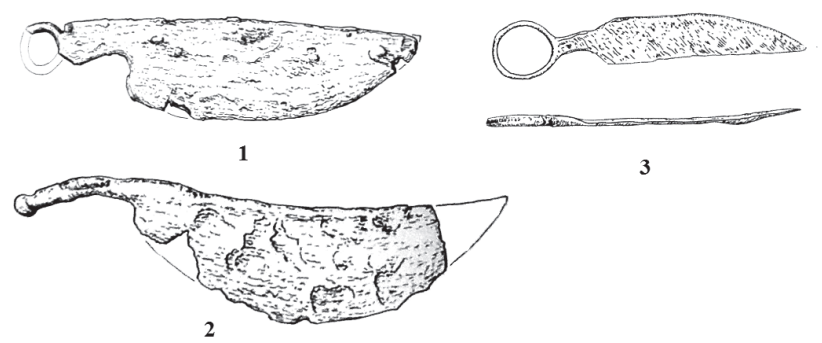

Obr. 5. Břitvy a nůž, 1: břitva (Weller - Kaiser - Heynowski 2016, 120, obr. 1.4.4.); 2: obloukovitý nůž (Weller - Kaiser - Heynoweski 2016, 112, obr. 1.2.3.); 3: malý nůž s prstencovitým zakončením úchopové části (Weller - Kaiser Heynowski 2016, 132, obr. 3). - Fig. 5 Razors and knife, 1: razor (Weller - Kaiser - Heynowski 2016, 120, Fig. 1.4.4.); 2: arcuate knife (Weller - Kaiser - Heynowski 2016, 112, Fig. 1.2.3.); 3: a small knife with an annular end of the grip part (Weller - Kaiser - Heynoweski 2016, 132, Fig. 3).

ostatní nálezy z ženského hrobu (přeslen, nádoby, pryskyřice) ale nepodporují hypotézu skalpelu, spíše užití při zpracování př́ze.

Lancetovitých tvarů nožů se v souboru artefaktů interpretovaných jako chirurgické nástroje objevuje celá řada. Lancety dle svého názvu nabývají tvaru malých kopí a slouží k perforaci měkkých tkání a cév (phlebotom). Lancetovité nože ve zkoumaném souboru představují dvoubřité nože, které však mohou mít celou řadu účelů. Nůž z Cíferu-Páce (kat. č. 22), nůž ze sady na kroužku z Dolních Lovčic (kat. č. 25), nůž (rovněž opatřený kroužkem k zavěšení) z Mušova (kat. č. 32), nůž s koncovým kroužkem a kroucenou rukojetí z Nitry-Párovských Hájů (kat.č. 33), nůž z Očkova (kat. č. 35) a nůž z Tureně (kat. $\check{c} .44)$ tedy nevypovídají o př́tomnosti specialisty provádějícího léčebné výkony v lokalitě nálezu. Pro osobní užití jedince mohl sloužit i jednobřitý nůž s půlměsícovitou čepelí z Očkova (kat.č. 34). Je pozoruhodné, že tyto nože jsou často nalézány ve spojení s klíčem, pravděpodobně původně zavěšené společně na kroužku, jako v př́padě nože z Dolních Lovčic (kat. c. 25). Mohlo tedy jít o běžnou sadu osobního vybavení jedinců.

U artefaktu ze Šoporni Štrkovce (kat. $\check{.} .43$ ) dnes není možné tvrdit, že byl opatřen ostř́m po obou hranách čepele, při blízkém prozkoumání se jedna ze stran jeví tenčí. Jde o drobný, původně možná precizní nástroj, nicméně kontext hrobu ani naleziště nenapovídá, že by měl sloužit k chirurgickým výkonům. Podobně je tomu u nože z Velkých Hostěrádek (kat. č. 47). Ten je zároveň doprovázen také klíčem a dalšími osobními předměty, ale také nůžkami a stř́íbrnou jehlou.

Na základě držadla z Hulína-Pravčic (kat. č. 38) nelze rozhodnout o užití předmětu. Pro dekor držadla nástroje byly předloženy analogie i z prostředí chirurgického instrumentária (Fojtík - F́lilek - Popelka 2015).
Bez pracovní části nástroje však není možné rozhodnout o účelu artefaktu. Tvar bezesporu odpovídá držadlu nástroje, výzdoba držadla však není sama o sobě určující pro přiřazení artefaktu k chirurgickému instrumentáriu. Autoři provedli srovnání např. s jehlicí z Augstu, kterou však E. Riha (1990, 179) určuje jako vlasovou. $K$ její interpretaci se vrátila také K. Gostenčnik (2004, 379-380) a vyslovila hypotézu, že podobné artefakty mohou představovat sondy, nebo kautery. Je vhodné navrhnout ustoupení od hypotézy „oční jehly“ (Fojtík - Fílek - Popelka 2015, 187). Hypotéza duté „oční jehly“ by měla být zcela vyloučena kvůli konstrukčním požadavkům na nástroj uvedeným výše. Vyloučit ale nelze teorii phlebotomu/ lancety. Autoři našli analogii v rámci instrumentária z měst zničených Vesuvem (Fojtík - Jílek - Popelka 2015, obr. 2: 1; v tomto textu je artefakt rovněž vyobrazen jako obr. 2: 3) a tvar otvoru na trn napovídá, že byl v držadle umístěn nástroj s plochou pracovní částí. Tvar horní části otvoru pro zasazení pracovní části je rovný, samotný otvor pro řap pak kulatý, což poukazuje na možné zasazení čepele nože.

\subsubsection{Jehly/bodce}

Bimetalické bodce z lokalit Bernhardsthal (kat. č. 18) a Mušov Neurissen I (kat. $\check{c} .31$ ) byly nalezeny povrchovým sběrem. Oba jsou analogiemi k bodci z Malých Výklek (kat. č. 30) nalezenému amatérským detektorovým průzkumem. Jistou podobnost lze pozorovat na zlomku bronzové hlavice tyčinkovitého nástroje ze Sudoměřic II (kat. $\breve{c} .42)$ a u zlom$\mathrm{ku}$ bronzového tyčinkovitého nástroje $\mathrm{z}$ Vacenovic (kat. c. 45) získaných z povrchových sběrů. U zlom$\mathrm{ku}$ ze Sudoměřic nelze odhadnout, zda byl artefakt původně bimetalický. Otvor v jednom z konců zlomku z Vacenovic však naznačuje, že byl původně spojen s další částí. Značně odlišný je zlomek stř́ibrné duté kulovité hlavice artefaktu z lokality Strážnice II (kat. č. 41) rovněž nalezené při povrchových sběrech. Není možné potvrdit, že pochází z tyčinkovitého nástroje, jak navrhuje T. Zeman $(2017,302)$. Tvar artefaktu nijak nevylučuje, že může jít o část šperku jiného tvaru, ani jeho výrobu v mladším období. Artefakt byl nalezen pomocí povrchových sběrů a datace do doby římské je proto problematická. Spolu s nožíkem z Velkých Hostěrádek (kat. č. 47) byla údajně nalezena i část stř́brné jehly, kterou však již K. Ludikovský a I. Peškař $(1978,85)$ ve sbírce nenašli, ačkoliv jí bylo přiděleno inventární číslo ( $\mathrm{Pa}$ 1894/38; Ludikouský - Peškař 1978, 85). Zdali se tedy jednalo o šicí jehlu (Egyptské artefakty stř́íbrných jehel s oušky se vyskytují již od 3. tisíciletí př. n. l.; Saber 2010, obr. 3a, 3b), část šperku, nebo jiný artefakt, tedy již není možné zjistit. Bimetalický bodec (kat. č. 30; zdobená mosazná hlavice, ze které vystu- 
puje robustní železná jehla) získaný detektorovým nálezem v ornici blízko lokality Mušov Neurissen I označil f. Fílek (2004) za nástroj k chirurgickým výkonům z doby římské. Pro označení artefaktu jako chirurgického nástroje neexistuje žádná opora, nástroj neodpovídá antickým popisům ani nalezeným exemplářuom ze známého instrumentária doby římské. Rovněž neexistuje důkaz pro původ předmětu v době římské. Několik analogických předmětů bylo nalezeno v různých prostředích střední Evropy, vždy bez kontextu v ornici.

\subsection{Artefakt sloužící ve smyslu dnešního zdravotnického prostředku}

Na zkoumaném území byl nalezen hliněný kruh (kat. c. 50), který byl v roce 2018 interpretován jako zdravotní pesar, tedy prostředek řešení poklesu dělohy (obdoba prostředku užívaného i dnes). Badatelé se tímto fenoménem v ženských hrobech z doby halštatské a laténské zabývají již od roku 1926 (Schmit 1926). Byl nalezen v hrobě č. 35 na pohřebišti v obci Palárikovo (dř́ve Slovenský Meder) a datován do období LT B2-LT C (Gardelková-Vrtelová - Ramsl $2018,95)$. Předmět tvarem odpovídá předpokládanému účelu. Artefakt je o něco lehčí, oproti průměrné hmotnosti zjištěné při průzkumu analogických předmětů $D$. Scherzlerem (1998). Je jistě vhodné uvažovat, že hliněný předmět by mohl při předpokládaném použití vlivem vlhkého a kyselého prostředí degradovat a drobné částice odlučované z povrchu by mohly zpo̊sobovat infekce, potenciálně i syndrom toxického šoku. Na úspěšnost použití zamýšleným způsobem tedy nelze usuzovat.

\section{Závěr}

Situace dospěla do stádia, kdy je označení „lékařský“ nebo "chirurgický" přidáno řadě artefaktů z doby železné a římské, které jsou pouze výrazně nebo netradičně zdobeny, popřípadě pro jejich účel není nalezeno jiné vysvětlení. Při určování artefaktů často není reflektována nutnost označovat importované primární nástroje $\mathrm{z}$ doby římské $\mathrm{v}$ archeologických katalozích jako „chirurgické" (kvůli oddělenému vývoji chirurgie a medicíny), ani nutnost zdržet se u nástrojů místního původu spojení artefaktů s lékařstvím jako vědou, nebo s chirurgií (nebot' není možné prokázat, zda léčebné výkony na našem území byly prováděny $\mathrm{v}$ souladu $\mathrm{s}$ paradigmaty lékařství nebo s principy chirurgie). Na místě je revidovat fond artefaktů, u nichž je předpokládáno užití k léčebným nebo diagnostickým účelům, a to bez přehnané touhy přispět novými artefakty do atraktivního prostředí archeologie medicíny.
Mezi artefakty z doby železné je možné zaznamenat nástroje, které mohou sloužit k léčebným výkonům. Spatuly ze Stradonic mohou být importované a teoreticky by mohly sloužit i k léčebným výkonům, protože v souboru artefaktů ze Stradonic jsou pravděpodobně také další artefakty, které mohly být $\mathrm{k}$ léčbě využívány. V nejasném kontextu je však vhodné spatuly považovat za sekundární nástroje. U zlomků artefaktů z Hrazan není možné rozhodnout o jejich původní kompletní podobě a účelu, za spatuly lze označit pouze artefakty ze Stradonic a Oberleiserbergu. Artefakt ze Stradonic ve tvaru malého kopí (kat. č. 12) mohl sloužit jako phlebotom a zastupovat tak primární nástroje na této lokalitě. U artefaktu z Baště (kat. č. 2) nebylo možné potvrdit předpoklad užívání jako nástroje $\mathrm{k}$ léčebným výkonům, k zodpovězení této otázky by snad mohla pomoci hlubší analýza předmětu. Interpretace artefaktů z oppida Tř́isov (kat. č. 13 a 14) je zvláště problematická. Oba předměty vykazují určité problémy při použití zamýšleným způsobem. Soubor artefaktů ze Slatiny nad Bebravou (kat. č. 7) mohl sloužit k léčebným výkonům a zasluhuje další zkoumání k prokázání či vyvrácení této domněnky, soubor údajně ze Stradonic (kat. č. 8) uložený ve sbírce Muzea Dr. B. Horáka se ale jeví spíše jako sada k výrobě obuvi nebo k jinému zpracování kůže. Za pilku ke kraniotomiím je považován artefakt z jeskyně Býčí skála (kat. č. 1) a podle analogií i popsaného kontextu je možné, že nástroj $\mathrm{k}$ předpokládanému účelu skutečně sloužil. U dlátek z Hrazan (kat. č. 3 a 4) není možné potvrdit účel k léčebným výkonům.

Mezi zkoumanými artefakty z doby římské jsou zejména nože a břitvy, u nichž přiřazení $\mathrm{k}$ chirurgickému instrumentáriu není vhodné. Je však možné považovat je za sekundární nebo kosmetické nástroje, mezi které jsou břitvy badateli běžně začleňovány (Weller - Kaiser - Heynowski 2016, 132). Srpovité nože a břitvy $\mathrm{z}$ hrobů byly ve značném počtu označeny za skalpely, a rovněž nožíkům s ostřím po obou hranách čepele byl přisuzován účel v chirurgii. Přitom jsou často doprovázeny klíčem a budí dojem užívání spíše k běžné každodenní potřebě. Artefakty z Bratislavy-Dúbravky (kat. č. 19 a 20) není možné s jistotou označit za spatuly. Spatula z Malacek (kat. ̌́. 29) a sonda ze Sekulí (kat. č. 39) však odpovídají analogiím.

Nástroje považované za víceúčelové nedokládají specializovanou činnost a nelze je tedy považovat za chirurgické. Pro interpretaci nožů jako primárních nástrojů je nutné vycházet také $\mathrm{z}$ nálezového kontextu. Zdobnost a kvalita zpracování je v současnosti archeology považována za jeden ze zásadních ukazatelů př́islušnosti artefaktu k instrumentáriu. $\mathrm{S}$ touto představou je ale jaksi v kontrastu výrok Lúkiana ze Samosaty (2. st. n. 1.), že by upřednostnil zkušeného 
chirurga s rezavým nožem před šarlatánem s ozdobným vybavením (Jackson 1988, 114). Z výroku je zřejmé, že obě varianty mohly ve 2 . st. n. l. nastat a že nejen zdobné instrumenty je nutné přičítat chirurgii. To tedy může platit i pro identifikaci skalpelů a chirurgických nožů. Pouze zdobnost artefaktu není dostatečným argumentem pro využívání při chirurgických výkonech.

\section{Finanční podpora}

Vybrané činnosti a cesty byly podpořeny ze zdrojů 2. ročníku soutěže o podporu pregraduální studentské vědecké činnosti FF UK 2019-2020.

\section{Katalog artefaktů nalezených na území ČR, SR a naddunajské části Dolního Rakouska}

\section{Artefakty interpretované jako nástroje $k$ léčbě a diagnostice $z$ doby železné}

1. „Trepanační pila“; lokalita: Adamov, Býčí skála, okr. Blansko, CZ; uložení: -

Publikace: Parzinger - Nekvasil - Barth 1995, obr. 426 Popis: Zlomek železného nástroje s pracovní částí opatřenou drobnými zoubky. Úchopová část artefaktu nezachována.

Rozměry: $\mathrm{D}$ = $60 \mathrm{~mm}$ (doměřováno z obrazu)

Materiál: Železo

Výzkum: -

Objekt: -

Další nálezy: -

Datace: -

Původní interpretace: Trepanační pila

Návrh interpretace: Pila ke kraniotomiím - artefakty vykazující jisté podobnosti uvádí Künzl (1995), možné antropologické doklady užívání podobných nástrojů v dosahu lokality prezentuje Stloukal (1981, 112-113)

Vyobrazení: Tab. 1: 1

2. „Drátěný předmět"; lokalita: Baštt, okr. Praha-východ, CZ; uložení: -; předmět veden pod č. sáčku 405

Publikace: Pecinovská - Baloun - Sankot 2014, 759;

Kučerová 2012, 13

Popis: Železný předmět tvořený ohnutým drátem s volnými konci pokrytými korozními produkty v podobě dvojice kuliček o průměru $4 \mathrm{~mm}$. Ve středové části se dochoval otisk kůže (Kučerová 2012,13), středová část je zaoblená (Pecinovská - Baloun - Sankot 2014, 759).

Rozměry: $\mathrm{D}=178 \mathrm{~mm}$; síla drátu $=2 \mathrm{~mm}$ (Pecinovská - Baloun - Sankot 2014, 753)
Materiál: Železo (Pecinovská - Baloun - Sankot, 2014, 753)

Výzkum: I. etapa výzkumu na jižním okraji obce, západně od silnice Líbeznice-Bašt' v poloze „Nad Dvorem“ pod dohledem ZIP, o. p. s., Plzeň, listopad-prosinec 2009 (Pecinovská - Baloun - Sankot 2014, 745)

Objekt: Objekt č. 122/2010, hrob, tělo muže výšky přibližně 168-169,5 cm (20-40 let) uloženo v natažené poloze na zádech ve směru $\mathrm{S}-\mathrm{J}$ s rukama podél těla. Artefakt umístěn mezi stehenními kostmi blíže levé straně pánve (Pecinozská - Baloun - Sankot 2014, 747) Další nálezy: Železný meč, železné kopí s tulejí, železná spona $2 \times$, železný kroužek s malými vývalky, železný kroužek 2x, amorfní železný zlomek a drobné zlomky železa (Pecinovská - Baloun - Sankot 2014) Datace: LT B2 (Pecinovská - Baloun - Sankot 2014, 758) Původní interpretace: Kleště neznámého účelu (Pecinovská - Baloun - Sankot 2014, 760)

Návrh interpretace: Pinzeta/kleště - nenalezena analogie, velmi křehká konstrukce artefaktu, další artefakty v hrobě nenapovídají spojení s léčbou Vyobrazení: Tab. 1: 2

3. „Lékařský bronzový nástroj“; lokalita: Hrazany, okr. Př́ibram (ORP Sedlčany), CZ; uložení: Depozitář Hornického muzea Př́ibram, č. 15/61-205

Publikace: Jansová 1992, 199, tab. 201:20; Jansová 1965, Obr. 22:11

Popis: Bronzový nástroj s hranatou pracovní stranou, jeden konec postranně rozšířený do tvaru špachtle, druhý vhodný jako sekáč, světle zelená patina (Jansová 1992, 65)

Rozměry: D = 9,6 cm, mírně zakřivený (Jansová 1992, 65)

Materiál: Bronz

Výzkum: V letech 1952-1963, Archeologický ústav Československé akademie věd, vedoucí výzkumu Libuše Jansová (Jansová 1992)

Objekt: Dům 13/61

Další nálezy: Zlomek kruhového železného hřebíku o průměru 0,4-0,5 cm, d = 3,9 cm (Jansová 1992, 65)

Datace: LT C2 (Jansová 1992)

Původní interpretace: Bronzový chirurgický nástroj, dlátko na operace kosti dle podobného artefaktu (Jacobi 1974, 99, Nr. 60, 96) z Manchingu (Jansová 1992, 199), Místní původ (Kysela, 2011; Drda - Rybová 1998, 163)

Návrh interpretace: Možné dlátko nebo jiný artefakt neznámého účelu, spojení s léčbou není možné doložit

Vyobrazení: Tab. 1:3

4. „Železné dlátko“; lokalita: Hrazany, okr. Př́íbram (ORP Sedlčany), CZ; uložení: Depozitář Hornického muzea Př́bram, 15/61-271 
Publikace: Jansová 1992, 200, Tab. 203: 4

Popis: Silně zrezivělé dláto se čtvercovým trnem (Jansová 1992, 66)

Rozměry: D = 9,5 cm (fansová 1992, 66)

Materiál: Železo

Výzkum: V letech 1952-1963, Archeologický ústav Československé akademie věd, vedoucí výzkumu Libuše Jansová

Objekt: Dům 13/61 (Fansová 1992, 200)

Další nálezy: L. Jansová (1992, tab. 204: 2) se domnívá, že rovněž sekundárně používaná jehlice z pozdní doby bronzové mohla sloužit jako chirurgická sonda (Jansová 1992, 200)

Datace: LT C2 (Jansová 1992)

Původní interpretace: Železné dlátko, chirurgický nástroj (Jansová 1992, 200)

Návrh interpretace: Artefakt neznámého účelu, možná dlátko, nejsou důkazy pro spojení s léčbou, kontext nenapovídá spojení s léčbou

Vyobrazení: Tab. 1: 4

5. „Tři železné nástroje“; lokalita: Hrazany, okr. Př́ibram (ORP Sedlčany), CZ; uložení: Depozitář Hornického muzea Př́íbram, č. 57/52, č. 64/52

Publikace: Jansová 1986, 97-98, tab. 18: 16, 17, 18

Popis:

a: 57/52, železný nástroj s širokým asymetrickým koncem ve tvaru špachtle a se čtvercovou rukojetí (Jansová 1986, 97, Taf. 18: 16)

b: 64/52, malý železný nástroj ve tvaru špachtle s tenkým čtvercovým stonkem (Jansová 1986, 98, Taf. 18: 17)

c: 64/52, železné šídlo/bodec s kulatou hřídelí a čtvercovým trnem (Jansová 1986, 98, Taf. 18: 18)

Rozměry:

a: d = $70 \mathrm{~mm}, \check{\mathrm{s}}=25 \mathrm{~mm}$ (Jansová 1986, 97, Taf. 18: 16)

b: d= $67 \mathrm{~mm}, \check{\mathrm{s}}=8 \mathrm{~mm}$ (Jansová 1986, 98, Taf. 18: 17)

c: d = $102 \mathrm{~mm}, \breve{s}=6 \mathrm{~mm}$ (Jansová 1986, 98, Taf. 18: 18)

Materiál: Železo

Výzkum: V letech 1952-1963, Archeologický ústav Československé akademie věd; vedoucí výzkumu Libuše Jansová

Objekt: Splachové vrstvy sondy 1/51, palisáda z východní strany opevnění (Jansová 1992, 200)

Další nálezy: Tenký plech obdélníkového tvaru (45 × $30 \mathrm{~mm}$ ), část děrovaného plechu šiŕky $23 \mathrm{~mm}$ (Jansová 1986, 98, Taf. 18: 18)

Datace: LT C2

Původní interpretace: Tři malé železné nástroje používané bud' jako toaletní nástroje, nebo mohly patřit "lékaři" (Jansová 1992, 200)

Návrh interpretace: Artefakty neznámého účelu, artefakt c odpovídá tvarem šídlu

Vyobrazení: Tab. 1: 5
6. „Spatula se středovým žebrem“; lokalita: Oberleiserberg, MG Ernstbrunn, PB Korneuburg, A; uložení: Soukromá sbírka

Publikace: Kern 1996, 388, Abb. 8

Popis: Spatula s hladkým dř́kem a spodní částí lopatky ve tvaru oblých výřezů. Přechod dř́ku a lopatky přes prvek ve tvaru písmene $\mathrm{V}$

Rozměry: Neuvedeny, neuvedeno měřítko u kresby Materiál: -

Výzkum: V letech 1976-1990 (Kern 1996, 388)

Objekt: -

Další nálezy: Drobné artefakty z bronzu a železa, např. spony Almgren 65 typu A, Beltz varianta $\mathrm{J}$, fragmenty náramků z kobaltového skla, z nichž některé byly zdobeny žlutým nebo bílým emailem (Kern 1996, 388)

Datace: LT C2-D2 (Kern 1996, 388)

Původní interpretace: Spatula (Kern 1996, 388)

Návrh interpretace: Spatula

Vyobrazení: Tab. 1: 6

7. „Hromadný nález 6 artefaktů“; lokalita: Slatina nad Bebravou, okr. Bánovce nad Bebravou, kr. Trenčínský

(Hradiště Udrina); uložení: AÚ SAV v Nitře, inv. č. 81 a-e (písmena nepřiřazena ke konkrétním artefaktům, obraz „f“ představuje nedochovaný artefakt)

Publikace: Pieta 2008, 112, 203

Popis: 6 artefaktů ze slovenského depotu s lékařskými nástroji

Rozměry:

a: d. = $160 \mathrm{~mm}, \max$. š. $=15 \mathrm{~mm}, \mathrm{hm} .=38,16 \mathrm{~g}$

b: d. $=155 \mathrm{~mm}, \max$. s. $=10 \mathrm{~mm}, \mathrm{hm} .=35,00 \mathrm{~g}$

c: d. $=153 \mathrm{~mm}, \max$. š. $=9 \mathrm{~mm}, \mathrm{hm} .=15,15 \mathrm{~g}$

d: d. $=115 \mathrm{~mm}$, max. š. $=7 \mathrm{~mm}, \mathrm{hm} .=9,83 \mathrm{~g}$

e: d. $=105 \mathrm{~mm}$, max. š. $=4 \mathrm{~mm}, \mathrm{hm} .=9,46 \mathrm{~g}$

f: d. = $118 \mathrm{~mm}, \max$. š. $=29 \mathrm{~mm}$ (doměřeno z kresby) Materiál: Železo

Výzkum: Detektorový nález z roku 2006

Objekt: Prostor hradiště s rozlohou 9 ha, fortifikační systém má z přístupné strany tři pásma opevnění, přičemž nejmenší vnitřní val opevňující Akropoli je možná pozdně a raně středověký (Pieta 2008, s. 112) Další nálezy: Hojně je zastoupeno hlavně kovářství, včetně výroby nástrojů a železných spon (Pieta 2008, s. 112) Datace: Většina jiných dříve získaných nálezů z hradiště patř́i do stupňů $\mathrm{C} 1$ a C2

Původní interpretace: Speciální medicínské nástroje - dlátko, spirálový vrták, hrot, speciální nože (Pieta 2008, s. 203)

Návrh interpretace: Dle analogií vykazuje některé vlastnosti instrumentů $\mathrm{k}$ léčebným výkonům Vyobrazení: Tab. 1: 7 
8. „Sada čtyř nástrojů údajně ze Stradonic“; lokalita: Stradonice, okr. Beroun, CZ (Údajně z oppida Stradonice); uložení: Muzeum Dr. B. Horáka v Rokycanech, inv. č. 04337 (a), 04329 (b), 04328 (c), 04330 (d)

Publikace: Sklenár 1986, 6

Popis: Na kartě vyplněné r. 1966 p. Samcem: „Nožík železný, rzí obalený, tvaru lékařského skalpelu. Na dlouhé rukojeti k břitu se zužující“ (a); „jehlice železná, pokrytá rzí“ (b); „jehlice železná, pokrytá rzí" (c); „tyčinkovitý nástroj“ (d)

\section{Rozměry:}

a: d = $99 \mathrm{~mm}, \breve{s}=7 \mathrm{~mm}, \mathrm{hl}=2 \mathrm{~mm}$; hm = 10,14 g (břit: $\mathrm{d}=24 \mathrm{~mm}, \check{\mathrm{s}}=12 \mathrm{~mm}$ )

b: d = $133 \mathrm{~mm}, \breve{s}=8 \mathrm{~mm}, \mathrm{hl}=8 \mathrm{~mm} ; \mathrm{hm}=22,46 \mathrm{~g}$

c: $\mathrm{d}=127 \mathrm{~mm}, \check{\mathrm{s}}=6,5 \mathrm{~mm}, \mathrm{hl}=6,5 \mathrm{~mm} ; \mathrm{hm}=13,49 \mathrm{~g}$

$\mathrm{d}: \mathrm{d}=90 \mathrm{~mm}, \breve{\mathrm{s}}=2 \mathrm{~mm}, \mathrm{hl}=2 \mathrm{~mm} ; \mathrm{hm}=1,87 \mathrm{~g}$

Materiál: Železo

Výzkum: Darováno Marií Wagnerovou (vdovou po horním správci dolu v Mirošově Oto Wagnerovi, který možná zakoupil jako součást rozsáhlého souboru, ve kterém jsou také falza) do muzea počátkem 20. století (Sklenář 1986, 8), přijato prof. B. Horákem, interpretováno 15. 7.1966 Adolfem Samcem

Objekt: -

Další nálezy: V souboru také keramická plastika, šídla, přesleny, kostěná jehlice, korálky, hrací kostka, nožík, ostruha, části spon (Sklenář 1986, 8-10)

Datace: LT D1-2?

Původní interpretace: Původně uvažováno o možném užívání artefaktu „a“ jako skalpelu, později považováno za falzum pro „velmi dobrý stav zachování"

Návrh interpretace: К̌emeslnické nástroje (a: řemeslnický nožík, b: šídlo, c: šídlo, d: šicí jehla)

Vyobrazení: Tab. 1: 8

9. „Spatula s plochou rukojetí“; lokalita: Stradonice, okr. Beroun, CZ; uložení: Národní muzeum, sbírka Bergerova, inv. č. 81459

Publikace: Píc 1903, 69, Tab. XXIV:10; Svobodová 1985, 653, Obr. 1:1; Kysela - Militký 2018, 291, Obr. 184; Databáze archeologické sbírky v.4.2

Popis: Spatula s plochým lžičkovitým koncem, s paličkovitým koncem nevýrazně vyděleným (Píc 1903, 69)

Rozměry: D = $188 \mathrm{~mm}, 66 \mathrm{~g}$ (Databáze archeologické sbírky v.4.2, inv. č. 81 459)

Materiál: Bronz (Databáze archeologické sbírky v.4.2, inv. č. 81 459)

Výzkum: Bergerova sbírka; st. č. Berger (Databáze archeologické sbirky v.4.2, inv. č. 81 459)

Objekt: -

Další nálezy: -

Datace: LT D (Databáze archeologické sbírky v.4.2, inv. č. 81 459)
Původní interpretace: Spatula (Píč 1903, 69); „lékařský nástroj?" (Databáze archeologické sbírky v.4.2, inv. č. 81 459)

Návrh interpretace: Spatula

Vyobrazení: Tab. 1: 9

10. „Spatula s plastickým žebrem“; lokalita: Stradonice, okr. Beroun, CZ; uložení: Národní muzeum, Bergerova sbírka, inv. č. 81460

Publikace: Píč 1903, 69, Tab. XXIV:9; Svobodová 1985, 653, Obr. 1:2; Databáze archeologické sbírky v.4.2 Popis: Bronzová tyčinka s koncem vesla mírně ohnutým, druhý konec ozdobně vykrojen na obou stranách. Středem prochází slabě plastické žebro (Databáze archeologické sbírky v.4.2, inv. č. 81 460)

Rozměry: D = 162 mm, 67 g (Databáze archeologické sbírky v.4.2, inv. č. 81460$)$

Materiál: Bronz (Databáze archeologické sbirky v.4.2, inv. č. 81 460)

Výzkum: Bergerova sbírka; st. č. Berger (Databáze archeologické sbírky v.4.2, inv. č. 81 460)

Objekt: -

Další nálezy: -

Datace: LT D (Databáze archeologické sbírky v.4.2, inv. č. 81 460)

Původní interpretace: Spatula (Píc 1903, 69); „lékařský nástroj?" (Databáze archeologické sbírky v.4.2, inv. č. 81 460)

Návrh interpretace: Spatula

Vyobrazení: Tab. 1: 10

11. „Spatula“; lokalita: Stradonice, okr. Beroun, CZ; uložení: Národní muzeum, Bergerova sbírka, inv. č. 81461

Publikace: Píč 1903, 69, Tab. XXIV:11; Svobodová 1985, 653, Obr. 1:3; Databáze archeologické sbírky v.4.2 Popis: Bronzová tyčinka stejného typu jako č. inv. 81459. Na přechodu mezi veslovitou částí a vlastní tyčinkou je předmět zdoben třemi prstenčitými proužky mezi třemi žlábky (Databáze archeologické sbírky v.4.2, inv. č. 81461 )

Rozměry: D = $158 \mathrm{~mm}$; 68 g (Databáze archeologické sbirky v.4.2, inv. č. 81 461)

Materiál: Bronz (Databáze archeologické sbírky v.4.2, inv. č. 81 461)

Výzkum: Bergerova sbírka; st. č. Berger (Databáze archeologické sbírky v.4.2, inv. č. 81 461)

Objekt: -

Další nálezy: -

Datace: LT D (Databáze archeologické sbírky v.4.2, inv. č. 81 461)

Původní interpretace: Spatula (Píc 1903, 69); „lékařský nebo psací nástroj?" (Databáze archeologické sbirky v.4.2, inv. č. 81 461)

Návrh interpretace: Spatula

Vyobrazení: Tab. 1: 11 
12. „Phlebotom/lanceta“; lokalita: Stradonice, okr. Beroun, CZ; uložení: Národní muzeum

Publikace: Píč 1903, 69, Tab. XXIV:12

Popis: Bronzový nástroj s kopinatým zakončením pracovní části a plochým zakončením úchopové části Rozměry: D = $72 \mathrm{~mm}$ (dopočteno z vyobrazení; Píc 1903, Tab. XXIV:12)

Materiál: Bronz

Výzkum: -

Objekt: -

Další nálezy: Spatuly

Datace: LT D (dle ostatních nálezů)

Původní interpretace: Kopíčko na pouštění žilou (Píc 1903, 69)

Návrh interpretace: Phlebotom/lanceta; možné označení jako lanceta na pouštění žilou, tedy „Aderlaßlanzette" podle Gostenčnik $(2004,372)$

Vyobrazení: Tab. 1: 12

13. „Skalpel“; lokalita: Tř́sov (oppidum), okr. Český Krumlov, CZ; uložení: Národní muzeum, inv. č. 135967

Publikace: Břeň 1975; Břeň 1984, 12; Kysela 2011,171172, obr. 2: 7

Popis: Plochý tyčinkovitý předmět na každém konci opatřený čepelí odlišného tvaru, jejichž předpokládané ostří směřuje na opačné strany. Hřbet čepele plynule navazuje na hranu rukojeti.

Rozměry: $\mathrm{D}=98 \mathrm{~mm}, \mathrm{tl}=1 \mathrm{~mm}$; kratší čepel: $\mathrm{d}=$ $12 \mathrm{~mm}$, š $=8 \mathrm{~mm}$; delší čepel: $\mathrm{d}=23 \mathrm{~mm}$, š $=8 \mathrm{~mm}$; rukojet': $\max$. š $=6 \mathrm{~mm}$, max. $\mathrm{tl}=1,4 \mathrm{~mm}$ (Databáze archeologické sbírky v.4.2, inv. č. 135967)

Materiál: Bronz (litý; Kysela 2011)

Výzkum: Výzkum Národního muzea vedený J. Břeněm v r. 1978

Objekt: Jižní okraj oppida, sonda B, vrstva č. 8 (Databáze archeologické sbírky v.4.2, inv. č. 135967)

Další nálezy: -

Datace: -

Původní interpretace: Skalpel

Návrh interpretace: Artefakt neznámého účelu, nelze potvrdit účel v léčbě

Vyobrazení: Tab. 1: 13

14. „Bronzový nožík/skalpel/lžička“; lokalita: Tř́sov (oppidum), okr. Český Krumlov, CZ; uložení: Národní muzeum, inv. č. 135960

Publikace: Kysela 2011, 171-172, obr. 2: 8

Popis: Předmět listovitého tvaru kovaný z bronzového drátu. Nepravidelně hráněný rovný dř́k k nasazení do rukojeti se rozšiřuje do tenké ne zcela symetrické čepele, hrana není zbroušena (Kysela 2011)

Rozměry: Celý nástroj: $\mathrm{d}=40 \mathrm{~mm}$, max. š $=7 \mathrm{~mm}$; dř́́k: průměr = 1,7 mm; čepel: $\mathrm{tl}=0,6 \mathrm{~mm}$ (Kysela 2011)
Materiál: Bronz

Výzkum: Výzkum Národního muzea vedený J. Břeněm v r. 1969

Objekt: Západní brána, severní strana severního křídla, střední pruh, střední část, hl. $20 \mathrm{~cm}$

Další nálezy: -

Datace: -

Původní interpretace: Bronzový nožík/skalpel (Kysela 2011)

Návrh interpretace: Artefakt neznámého účelu, nelze potvrdit funkci jako skalpelu

Vyobrazení: Tab. 1: 14

\section{Artefakty interpretované jako nástroje $\mathrm{k}$ léčbě a diagnostice $\mathrm{z}$ doby římské}

15. „Skalpely s rovnou plnou rukojetí“; lokalita: Abrahám, Kostolná pri Dunaji, Sládkovičovo, kr. Galanta, SK; uložení: -

Publikace: Kolník 1980, Taf. 15, 28, 87c; Kolník 2004, Abb. 1, 2

Popis: a: Nůž se zakřivenou pevnou čepelí a dlouhou plnou rukojetí, b: Nuž s masivní zploštělou rukojetí (Kolník 2004)

Rozměry: a: $d=170 \mathrm{~mm}, \mathrm{~b}: \mathrm{d}=240 \mathrm{~mm}$

Materiál: Bronz

Výzkum: -

Objekt: a: žárový hrob 14 dospělého jedince, b: žárový hrob 87 (Kolník 2004)

Další nálezy: a: spona Almgren 68, bronzové nůžky, glazovaný skyphos s motivem břečtanových úponů, b: urna, spona Almgren 75, roztavené kousky skla (Kolník 1980)

Datace: a: polovina 1. století, b: počáteční fáze B2 (Kolník 1980)

Původní interpretace: „Skalpely s rovnou plnou rukojetíc (na základě formální podobnosti s moderními skalpely podle Kolník 2004)

Návrh interpretace: Nưž neznámého účelu/univerzální, spojení s chirurgií nelze doložit

Vyobrazení: Tab. 2: 15

16. „Skalpel se zakřivenou čepelí a očkem“; lokalita: Abrahám, Kostolná pri Dunaji, Sládkovičovo, kr. Galanta SK; uložení: -

Publikace: Kolník 1980, 39 Taf. 27, 81d; Kolník 2004, Abb. 6:1, Abb. 7

Popis: Železný nůž se zakřivenou širokou čepelí, rukojet' s profilovaným středovým uzlem a prstencovým očkem (Kolník 2004)

Rozměry: $\mathrm{D}=13 \mathrm{~cm}$

Materiál: Železo

Výzkum: -

Objekt: Žárový hrob č. 81 dospělého jedince ve věku 40-60 (Kolnik 1980) 
Další nálezy: Urna, spony: očkovité, Almgren 45, dvě výrazně profilované brože ve tvaru Almgren 67 (Kolník 1980)

Datace: ̌̌ B1a (Kolník 1980)

Původní interpretace: „Skalpel (?) se zakřivenou čepelí a očkem“ (Kolník 2004)

Návrh interpretace: Srpovitá břitva s koncovým kroužkem

Vyobrazení: Tab. 2: 16

17. „Nůž se zakřivenou čepelí"; lokalita: Altenmarkt im Thale, Gem. Hollabrunn, pol. Bez. Hollabrunn, A; uložení: NMW / P. A. a Museum Hollabrunn, inv. č. 15170

Publikace: Pollak 1980, 10-11, Taf. 1: 1; Kolník 2004, 199

Popis: Železný nůž, čepel a rukojet' zakřivené, rukojet' také opatřena knoflíky (Pollak 1980, 10-11)

Rozměry: D = 120 mm (Pollak 1980, 10-11)

Materiál: Železo (Pollak 1980, 10-11)

Výzkum: Roku 1890 byly ve staré štěrkové jámě na konci města (nyní opět zalesněné) odkryty zbytky pohřebiště z 1 . století, téměř zcela zničeného slovanským hřbitovem a těžbou štěrku, výzkum vedl L. Franz (Pollak 1980, 10-11)

Objekt: Popsáno jako hrob, ale kontext hrobu ani přesné umístění nelze dnes rekonstruovat (Pollak 1980, 10-11)

Další nálezy: Urna, fragment silně profilované noricko-panonské bronzové brože, fragment silně profilované bronzové spony

Datace: 1. století n. l. (Pollak 1980, 10-11)

Původní interpretace: Nůž se zakřivenou čepelí (Pollak 1980, 11), Skalpel (?) se zakřivenou čepelí a očkem (Kolník 2004, 199)

Návrh interpretace: Srpovitý nůž

Vyobrazení: Tab. 2: 17

18. "Jehlicovitý bodec s profilovanou hlavicí"; lokalita: Bernhardsthal, VB Mistelbach, A; uložení: Soukromá sbírka S. Allebauera

Publikace: Adler - Schmelzenbarth 1991; Adler 1992, 281, Abb. 629; fílek 2004, Obr. 3:3

Popis: Jehlicovitý bodec s profilovanou hlavicí (fílek 2004)

Rozměry: $\mathrm{D}=144 \mathrm{~mm}$

Materiál: Železo a bronz (fílek 2004, 36)

Výzkum: Povrchový sběr roku 1991 (fílek 2004, 36)

Objekt: -

Další nálezy: -

Datace: -

Původní interpretace: Stilus (Adler 1992, 281), analogie $\mathrm{k}$ jehle $\mathrm{k}$ léčebným výkonům (Fílek 2004, 36)

Návrh interpretace: Neexistují analogie mezi chirurgickými nástroji

Vyobrazení: Tab. 3: 18
19. „Spatula“; lokalita: Bratislava-Dúbravka, okr. Bratislava IV, SK; uložení: -

Publikace: Elschek 2017, 165, Taf. 119:2

Popis: Fragment tyčinkovitého předmětu s koncem rozšíreným do plošky

Rozměry: D = 47 mm (Elschek 2017, 165)

Materiál: Bronz (Elschek 2017, 165)

Výzkum: Povrchový sběr (Elschek 2017, 165)

Objekt: -

Další nálezy: -

Původní interpretace: „Spatula?, lékařský nástroj?“ (Elschek 2017, 165)

Návrh interpretace: Není možné s jistotou označit za spatulu

Vyobrazení: Tab. 3: 19

20. „Bronzová spatula“; lokalita: Bratislava-Dúbravka, okr. Bratislava IV, SK; uložení: -, inv. č. 64/1989

Publikace: Elschek 2017, 146, Taf. 36

Popis: Fragment tyčinkovitého předmětu s koncem rozšířeným do plošky

Rozměry: D = 47 mm (Elschek 2017, 146)

Materiál: Bronz (Elschek 2017, 146)

Výzkum: Šetření germánského knížecího sídla s římskými budovami provedený v letech 1982-1993 Archeologickým ústavem SAV pod vedl T. Kolník a jeho spolupracovníci (K. Elschek zástupce vedoucího výzkumu v letech 1985 a 1988-1993)

Objekt: Objekt 6/88 - chata/polozemnice

Další nálezy: Celkem 131 germánských a 16 římských fragmentů keramiky (27-29/1989), mazanice, zvířecí kosti, drobné kovové nálezy (Elschek 2017, 146)

Datace: 2. pol. 4. stol. n. 1 .

Původní interpretace: „Bronzová spatula - lékařský nástroj?" (Elschek 2017, 146)

Návrh interpretace: Není možné s jistotou označit za spatulu

Vyobrazení: Tab. 3: 20

21. „Srpkovitý nůžc; lokalita: Břeclav, okr. Břeclav, CZ; uložení: Moravské zemské muzeum, inv. č. $135 / 35$

Publikace: Tejral 1970, 109, 134, 166, obr. 13: 4; Kolník 2004, 200

Popis: Srpkovitě prohnutý nůž se stonkovitým trnem, jehož konec je ukončen knoflíkem (Kolnik 2004, 200; Tejral 1970, 166)

Rozměry: D = 100 mm (Tejral 1970, 166)

Materiál: Železo (Tejral 1970, 166)

Výzkum: V roce 1935 byl při stavbě Břeclavského letiště rozrušen žárový hrob, jehož inventář daroval Ing. Hindels Moravskému muzeu (Tejral 1970, 166) Objekt: Žárový hrob (Tejral 1970, 166)

Další nálezy: Např. fragmenty naběraček a cedníku, spodní část popelnice, bronzová vendická spona se širokým páskovým lučíkem, zbytky bronzové pánve, 
železný nůž s rovnou čepelí a trnem odsazeným pouze na jedné straně (Tejral 1970, 166)

Datace: II. fáze stupně B1 na Moravě (Tejral 1970, 109)

Původní interpretace: Srpkovitý nůž (Tejral 1970, 134), "Skalpel (?) se zakřivenou čepelí a očkem“ (Kolník 2004, 200)

Návrh interpretace: Srpovitá břitva/nůž

Vyobrazení: Tab. 2: 21

22. „Lancetovitý nůž“; lokalita: Cifer-Pác, okr. Trnava, SK; uložení: Předměty z údajného hrobu zakoupilo roku 1931 Vlastivedné

múzeum v Bratislave (dnešní Archeologické múzeum SNM; Kolník 2004, 201)

Publikace: Kolník 2004, 201, Abb. 11: 14

Popis: Malý nůž ve tvaru lancetu (Kolník 2004, 201)

Rozměry: $\mathrm{D}=118 \mathrm{~mm}$ (dopočteno z kresby)

Materiál: -

Výzkum: -

Objekt: V bezprostřední blízkosti objektu 58, hrob (Kolník 2004, 201)

Další nálezy: -

Datace: 1. polovina 4. století n. 1. (Kolník 2004, 201) Původní interpretace: Lancetovitý nůž (Kolník 2004, 201)

Návrh interpretace: Nožík neznámého účelu, spojení s chirurgií nelze doložit

Vyobrazení: Tab. 2: 22

23. „Chirurgický nůž“; lokalita: Dobřichov-Pičhora, Okr. Kolín, CZ; uložení: NM

Publikace: Píč 1905, 299-300, Taf. LXXX: 25; Eggers 1951, 41, kat. č. 1754; Droberjar 1999, 233, Tab. 36: 7; Kolník 2004, 197, Abb. 4:1

Popis: Nůž s pevnou plnou rukojetí se šestihranným průřezem (Kolník 2004, 197)

Rozměry: $130 \mathrm{~mm}$

Materiál: Železo (Droberjar 1999, 233), rukojet' původně považována za bronzovou (Kolník 2004, 197)

Výzkum: Na jaře r. 1906 nalezli dělníci na ostrožně zvané Pičhora, poblíž Dobřichovského kostela při dobývání štěrku, popelnice a během měsíce pak vykopal J. Waněk celkem 131 hrobů, z kterých zachováno 6 bronzových a 82 hliněných popelnic. Darováno Museu království Českého, zkoumal J. Waněk, popsal J. L. Píč (Píč 1905, 299-300)

Objekt: Žárový hrob 26

Další nálezy: Spony, jehlice, nože

Datace: Doba římského císařství (Píč 1905, 299-300)

Původní interpretace: Chirurgický nůž/skalpel s rovnou a plnou rukojetí (Kolník 2004, 197)

Návrh interpretace: Nůž neznámého účelu, spojení s chirurgií nelze doložit

Vyobrazení: Tab. 2: 23
24. „Skalpely se zakřivenou čepelí a očkem“; lokalita: Dobřichov-Pičhora, Okr. Kolín, CZ; uložení: NM

Publikace: Píc 1905, 299-300, Tab. LXX: 18, Tab. LXXIII: 4, Tab. LXXXIII: 24; Droberjar 1999; Kolník 2004, 197, Abb. 4: 5, 6, 8

Popis:

a: Nůž s rovným týlem a rovnou rukojetí a se zaobleným břitem. Rukojet' je po cca $10 \mathrm{~mm}$ od konce opatřena kulovitým knoflíkem.

b: Nưž esovitého tvaru, tedy s konvexním týlem přecházejícím do konkávní rukojeti ukončené kulatým knoflíkem.

c: Nůž esovitého tvaru, tedy s konvexním týlem přecházejícím do konkávní rukojeti ukončené otevřeným očkem k zavěšení.

Rozměry: a: $\mathrm{d} \doteq 120 \mathrm{~mm}, \mathrm{~b}: \mathrm{d} \doteq 103 \mathrm{~mm}, \mathrm{c}: \mathrm{d} \doteq$ $160 \mathrm{~mm}$

Materiál: a, c: železo?, b: bronz?

Výzkum: Na jaře r. 1906 nalezli dělníci na ostrožně zvané Pičhora, poblíž Dobřichovského kostela při dobývání štěrku, popelnice a během měsíce pak vykopal J. Waněk celkem 131 hrobů, z kterých zachováno 6 bronzových a 82 hliněných popelnic. Darováno Museu království Českého, zkoumal J. Waněk, popsal J. L. Píč (1905, 299-300)

Objekt: Žárový hrob

Další nálezy: Spony, jehlice, nože

Datace: Doba římského císařství (Píč 1905, 299-300) Původní interpretace: „Skalpely se zakřivenou čepelí a očkem" (Kolník 2004, 197)

Návrh interpretace: a: nožovitá břitva; b, c: srpovitá břitva

Vyobrazení: Tab. 2: 24

25. „Lancetovitý nůž“; lokalita: Dolné Lovčice (dříve Alsólóc), okr. Trnava, SK; uložení: Mad'arské národní muzeum

Publikace: Bóna 1963, 241, 243 Taf. 43: 15; Kolník 2004, Abb. 12:6

Popis: Sada železných předmětů zavěšených na bronzovém prstenci. Nožík ve tvaru hrotu kopí a železný klíč se zahnutým koncem ve tvaru háčku (Bóna 1963, 243)

Rozměry: $140 \mathrm{~mm}$

Materiál: Nožík bronz, klíč železo

Výzkum: Podle první zprávy F. Römera z této lokality bylo v zahradě A. Prileszky na ploše $36 \mathrm{~m} \mathrm{v}$ průměrné hloubkce jedné stopy nalezeno 40 urnových hrobů. Podle Römerova tvrzení byly v urnách nože, spony a jehly. Römer chybně oznámil, že Mad'arskému národnímu muzeu doručil pět uren (neúmyslný nesprávný výklad informací o inventáři). Některé nálezy byly darovány A. Prileszkym dne 1. 2. 1873 Národnímu muzeu (Bóna 1963, 241)

Objekt: Urnové hroby 
Další nálezy: Urny, železné klíče, přezky, bronzová „pinzeta“, bronzové svorky, bronzový prsten, spony, bronzová pouzdra, dvouhrotá vidlička, bronzový př́ivěsek s otočnou hřídelí začínající smyčkou a pokračující ve spirálovém trubkovém hř́deli a opatřený háčkem na druhém konci, ke kterému je připevněn kus propleteného bronzového drátu (Bóna 1963, 243) Datace: DǨ

Původní interpretace: Lancetovitý nůž (Kolník 2004, 200)

Návrh interpretace: Kapesní sada klíče s nožíkem, spojení s chirurgií nelze doložit (některé položky mezi dalšími nálezy se jeví jako recentní předměty) Vyobrazení: Tab. 2: 25

26. „Nůž“; lokalita: Eggendorf am Wagram, Gem. Stetteldorf am Wagram, pol. Bez. Korneuburg A; uložení: Museum Stockerau, inv. č. 71132

Publikace: Pollak 1980, 27, Taf. 14:2; Kolník 2004, 199 Popis: Fragment těžce zkorodovaného železného nože s prstencovým koncem (Pollak 1980, 27)

Rozměry: D = 123 mm (Pollak 1980, 27)

Materiál: Železo

Výzkum: V roce 1939 nalezli E. Rotter a O. Wildschek při zkoumání slovanského pohřebiště z 9 . století (Pollak 1980, 27)

Objekt: Žárový hrob na pozemku 1099 ve Flur Leberäcker (Pollak 1980, 27)

Další nálezy: Urna, fragment těžce zkorodovaných železných nůžek (178 mm; Pollak 1980, 27)

Datace: Přelom 1. st. n. 1 .

Původní interpretace: Nůž (Pollak 1980, 27), „Skalpel (?) se zakřivenou čepelí a očkem" (Kolník 2004, 199)

Návrh interpretace: Nožovitá břitva

Vyobrazení: Tab. 2: 26

27. „Skalpel“; lokalita: Kostelec na Hané, okr. Prostějov, CZ; uložení: Muzeum Prostějov, inv. č. 4684

Publikace: Zeman 1961, 169; Obr. 81 D: e; Kolník 2004, 199

Popis: Železný nožík s masivní válcovitou rukojetí (Zeman 1961, 168-169)

Rozměry: $\mathrm{D}$ = cca $180 \mathrm{~mm}$ (odhad podle kresby)

Materiál: Železo

Výzkum: Výzkum Ant. Gottwalda v letech 1925-1930

(parcela 1531/1 v roce 1927; Zeman 1961, 168-169)

Objekt: Hrob 422, hrob interpretovaný podle přeslenu jako ženský (poškozený orbou)

Další nálezy: V popelnici mezi zbytkem kostí také přeslen (hráněný hliněný), dno nádoby, spona, pryskyřice; zbytky skleněné nádoby (poháru z nažloutlého skla) a zbytky mísovité nádoby (Zeman 1961, 168-169)

Datace: Pozdí DǨ (Zeman 1961)

Původní interpretace: Nůž (Zeman 1961, 168-169), skalpel (Kolník 2004, 199)
Návrh interpretace: Nůž, kontext ani tvar nenapovídá účelu $\mathrm{k}$ léčbě

Vyobrazení: Tab. 2: 27

28. „Skalpel (?) se zakřivenou čepelí a očkem“; lokalita: Láb, okr. Malacky, SK; uložení: SNM?

Publikace: Eisner 1933, 209, Taf. 68: 1; Kolník 2004, 200 Popis: Půlměsícovitá břitva s rukojetí zakončenou knoflíkem

Rozměry: -

Materiál: Železo

Výzkum: -

Objekt: Žárový „hrob bojovníka“ (Eisner 1933, 209)

Další nálezy: Železný meč, skoby z pochvy, železná štítová puklice, picí roh, bronzová pánev (Eisner 1933, 209)

Datace: 1. pol. 1. stol. (Eisner 1933, Tab. 68)

Původní interpretace: „Skalpel (?) se zakřivenou čepelí a očkem“ (Kolník 2004, 200)

Návrh interpretace: Srpovitá břitva

Vyobrazení: Tab. 3: 28

29. „Spatula“; lokalita: Malacky, okr. Malacky, SK; uložení: Archeologické muzeum Slovenského národního muzea v Bratislavě

Publikace: Hladíková 2019, 89, 91, obr. 2: 1a, 1b)

Popis: Fragment spatuly s horní částí vykovanou do listovitého tvaru se zašpičatělým koncem. Hlavice se zužuje směrem ke krku. Průřez má tvar elipsoidu se zašpičatělým koncem (Hladíková 2019, 91)

Rozměry: Celková $\mathrm{d}=98 \mathrm{~mm}$, hlavice: $\mathrm{D}=60 \mathrm{~mm}$, max š. $=9 \mathrm{~mm}$, hloubka $=2 \mathrm{~mm}$, trapézovité rozšíření: š. $8 \mathrm{~mm}$, hl. $2 \mathrm{~mm}$, tyčinkovité tělo: průměr = 2 $\mathrm{mm}, \mathrm{hm}=5,52 \mathrm{~g}$ (Hladíková 2019, 91)

Materiál: Mosaz (Hladíková 2019, 89)

Výzkum: Povrchová prospekce Archeologického muzea Slovenského národního muzea v Bratislavě v roce 2009 (Hladíková 2019, 90)

Objekt: -

Další nálezy: -

Datace: V konkrétním kontextu 1. - 2. stol. (obecně 1. - 4. století; Hladíková 2019, 94)

Původní interpretace: Spatula

Návrh interpretace: Spatula

Vyobrazení: Tab. 3: 29

30. „Bimetalický bodec“; lokalita: Malé Výkleky, okr. Pardubice, CZ; uložení: Východočeské muzeum v Pardubicích, inv. č. B/135/g

Publikace: nepublikováno (zpracování na základě smlouvy povolilo a artefakt zapůjčilo Východočeské muzeum v Pardubicích, Zámek 2, 53002 Pardubice, IČO: 14450542)

Popis: Bimetalický jehlicovitý artefakt (zdobená mosazná hlavice, ze které vystupuje robustní železná jehla) 
Rozměry: Celková $\mathrm{d}=120 \mathrm{~mm}$, hlavice: $\mathrm{d}=10 \mathrm{~mm}$ + $8 \mathrm{~mm}$, max. š $13 \mathrm{~mm}$, krček: d = $30 \mathrm{~mm}$, max. š 6,5 mm, celková hm. = 27,45 g, otvor v hlavici prům. 2,1 $\mathrm{mm}$

Materiál: bronzová hlavice, železný bodec

Výzkum: Detektorový nález spolupracující soukromé osoby

Objekt: -

Další nálezy: -

Datace: -

Původní interpretace: -

Návrh interpretace: Jehlicovitý artefakt neznámého účelu

Vyobrazení: -

31. "Jehlicovitý bodec"; lokalita: Mušov Neurissen I, CZ býv. okr. Břeclav, Jihomoravský kraj; uložení: Soukromá sb. (M. Vokáč), AU AVČR

Publikace: fúlek 2004, Obr. 1

Popis: Profilovaná hlavice tyčinkovitého předmětu zakončená kuličkou. Tyčinka je zdobena střídajícími se žlábky a vývalky, koncová kulička členěna třemi rytými pásy, které jsou dále zdobené svislými kosými liniemi (fúlek 2004)

Rozměry: D = $45 \mathrm{~mm}, \check{\mathrm{s}}=13 \mathrm{~mm}$ (fílek 2004)

Materiál: Železo, bronz (fílek 2004)

Výzkum: Povrchový sběr v roce 2002 (fílek 2004)

Objekt: -

Další nálezy: -

Datace: Na lokalitě doloženo neolitické a raně středověké osídlení a germánské osídlení z 2. a 3. století (Kavánová - Jelínková 2002, 337)

Původní interpretace: Jehlicovitý lékařský nástroj (fílek 2004)

Návrh interpretace: Jehlicovitý artefakt neznámého účelu

Vyobrazení: Tab. 3: 31

32. „Lancetovitý nůž“; lokalita: Mušov, okr. Brno-venkov, CZ; uložení: Okresní muzeum Mikulov č. 11

Publikace: Tejral 1971, 37, obr. 5: 2; Kolník 2004

Popis: Celokovový železný nuž lancetovitého tvaru, jehož úzká rukojet' zdobená po obou stranách nízkými lištami vybíhá v ouško opatřené železným závěsným kroužkem (Tejral 1971, 54)

Rozměry: D = 156 mm (Tejral 1971, 54)

Materiál: Železo (Tejral 1971, 54)

Výzkum: V roce 1934 narazil E. Lamme1 při kopání př́ḱopu pro vinné sazenice na pravém břehu Dyje na žárový hrob (Tejral 1971, 54)

Objekt: Žárový hrob (Tejral 1971, 54)

Další nálezy: Klíč, urna, spona (železná s válcovitou hlavici, užším lučíkem a vyšším zachycovačem), rovný nožík s krátkou čepelí, pravidelným hrotem a oboustranně odsazeným trnem (Tejral 1971, 54)
Datace: 2. třetina 2. století (Tejral 1971, 54)

Původní interpretace: Lancetovitý nůž (Kolník 2004, 200)

Návrh interpretace: Nožík kapesní, spojení s chirurgií nelze doložit

Vyobrazení: Tab. 2: 32

33. „Lancetovitý nůž“; lokalita: Nitra-Párovské Háje, okr. Nitra, SK; uložení: -

Publikace: Pieta - Ruttkay 1997, Abb. 3:14; Kolník 2004, 201

Popis: Malý nůž ve tvaru lancety s kroucenou rukojetí (Kolník 2004, 201)

Rozměry: $\mathrm{D}=130 \mathrm{~mm}$ (doměřeno z obrazu)

Materiál: Železo

Výzkum: Záchranné výzkumy od roku 1972 (Pieta Ruttkay 1997)

Objekt: -

Další nálezy: Na lokalitě také provinciální keramika, zlomky skla, spony, pozdně imperiální mince (Pieta-Ruttkay 1997)

Datace: Pozdní DǨ (Kolník 2004, 201)

Původní interpretace: Lancetovitý nůž souvisící $\mathrm{s}$ římskými lékařskými nebo kosmetickými nástroji (Kolník 2004, 201)

Návrh interpretace: Nožík neznámého účelu, spojení s chirurgií nelze doložit

Vyobrazení: Tab. 2: 33

34. „Skalpel (?) se zakřivenou čepelí a očkem“; lokalita: Očkov, okr. Nové Mesto nad Váhom, SK; uložení: -

Publikace: Kolník 1964; 2004, 200, Abb. 6:2

Popis: Železný nůž se závěsným kroužkem (Kolník 2004, 200)

Rozměry: -

Materiál: Železo

Výzkum: -

Objekt: Urnový hrob č. 117, mladý jedinec

Další nálezy: Zlomky štítu, kování římského opasku a kování z typu Eggers 29 (Kolník 2004, 200)

Datace: $\check{\mathrm{R}} \mathrm{C} 1$

Původní interpretace: Skalpel (?) se zakřivenou čepelí a očkem (Kolník 2004, 200)

Návrh interpretace: Nožík neznámého účelu, spojení s chirurgií nelze doložit

Vyobrazení: Tab. 3: 34

35. „Lancetovitý nůž“; lokalita: Očkov, SK; uložení: Publikace: Kolník 1964; 2004, 200, Abb. 6:4

Popis: Nůž lancetovitého tvaru (Kolník 2004, 200)

Rozměry: -

Materiál: -

Výzkum: -

Objekt: Hrob 158

Další nálezy: - 
Datace: -

Původní interpretace: Lancetovitý nůž (Kolník 2004, 200)

Návrh interpretace: Nožík neznámého účelu, spojení s chirurgií nelze doložit

Vyobrazení: Tab. 3: 35

36. „Skalpel“; lokalita: Ohništtany (okr. Hradec Králové, Královéhradecký kraj); uložení: Inv. č. 52637 ve sbírce Národního muzea v Praze pod lokalitou „Ohništany (u N. Bydžova) - u silnice při Zálesí"“.

Publikace: Píc 1905, 303, XLIX: 15; Droberjar 2006; Černý 2009, 2

Popis: Nưž s ostřím a týlem obloukovitého tvaru a rukojetí zdobenou dvěma př́čnými drážkami (Černý 2009, 82)

Rozměry: $125 \mathrm{~mm}$

Materiál: Železo

Výzkum: Daroval velkostatkář Edm. Kadlík (v letech 1902-1903). Na polích E. Kadlíka - po obou stranách silnice při Zálesí žárové hroby (Píc 1905, 303).

Objekt: Hrob 6: Fe nůž/skalpel, Fe břitva

Další nálezy: Hrob 3: br. spona pravděpodobně typu Almgren 236 (frag.), frag. Fe nože. Rozrušené hroby: souprava cedníku a naběračky Eggers (frag.) s kolky C MANLVANNI a C M // LIV, spona s očky (frag.) typu Haltern(?), spona Almgren 236 (frag.), Ag kování, pásová zápona (frag.) typu Garbsch G1b, br. nákončí picího rohu typu Andrzejowski D1, br. srpovitý nůž/břitva (Droberjar 2006, 687-688, č. 41) Datace: К̌ B1 (Černý 2009, 82)

Původní interpretace: Skalpel (Droberjar 2006, 687-688)

Návrh interpretace: Nůž/nožovitá břitva, spojení s chirurgií nelze doložit

Vyobrazení: Tab. 2: 36

37. „Skalpel“; lokalita: Peder, SK; uložení: -

Publikace: Lámiová-Schmiedlová 1969, 420 Abb. 11: 20; Kolník 2004, 200

Popis: Železná obloukovitá břitva s držadlem s koncovým kroužkem (Lámiová-Schmiedlová 1969, 420)

Rozměry: $\mathrm{D}=127 \mathrm{~mm}$

Materiál: Železo

Výzkum: V roce 1963

Objekt: Sektor 10 - chata z Dř

Další nálezy: Dva železné nože d = $118 \mathrm{~mm}$ a $86 \mathrm{~mm}$, železná jehlice $\mathrm{d}=72 \mathrm{~mm}$, železný kroužek průměr = $38 \mathrm{~mm}$, zlomky 15-20 mm

Datace: Materiál odtud byl z různých historických epoch, proto nedatováno (Lámiová-Schmiedlová 1969, 420)

Původní interpretace: Břitva (Lámiová-Schmiedlová 1969, 420), „Skalpel (?) se zakřivenou čepelí a očkem" (Kolník 2004, 200)
Návrh interpretace: Srpovitá břitva

Vyobrazení: Tab. 2: 37

38. „Držadlo nástroje“; lokalita: Pravčice-Hulín, okr. Kroměříž, CZ; uložení: Muzeum Kroměřŕžska v Kroměříži, A 22760

Publikace: Fojtík - Fílek - Popelka 2015, 185, Obr. 2: 1 Popis: „Rukojet' nástroje je zdobená reliéfním dekorem v podobě suků. Rukojet' je na bázi užší a směrem $\mathrm{k}$ hlavici se rozšiřuje. Spodní část je opatřena otvorem hlubokým $8 \mathrm{~mm}$ a podélným tenkým žlábkem. Hlavice je od vlastní rukojeti odsazená. Odsazená část je členěna jedním horizontálním žebrem, které nese kruhovou bochánkovitou hlavici“ (Fojtík fílek - Popelka 2015, 185)

Rozměry: Celková $\mathrm{d}=65 \mathrm{~mm}$, báze: $\check{\mathrm{s}}=8 \mathrm{~mm}$, hlavice: $\check{\mathrm{s}}=16 \mathrm{~mm}$, otvor: prům. $=4 \mathrm{~mm}$, délka $6,5 \mathrm{~cm}$, hmotnost $=39,85 \mathrm{~g}$ (Fojtík - Fílek - Popelka 2015)

Materiál: Bronz/mosaz (Fojtík - Fílek - Popelka 2015) Výzkum: Detektorový nález soukromé osoby (Fojtík - Fílek - Popelka 2015)

Objekt: -

Další nálezy: Bronzová římsko-provinciální kolínkovitá spona s polokruhovitou záhlavní destičkou zdobenou po obvodu rytým motivem vlčích zubů (Fojtík - Fílek - Popelka 2015)

Datace: 1. st. př. n. 1. do 1. st. n. 1. / 3. až 4. st. n. 1. (Fojtík - Fílek - Popelka 2015)

Interpretace: „Držadlo římského (lékařského?) nástroje" (Fojtík - Jílek - Popelka 2015)

Návrh interpretace: Bez pracovní části nástroje nelze rozhodnout, pravděpodobně nůž

Vyobrazení: Tab. 3: 38

39. „Sonda“; lokalita: Sekule, okr. Senica, SK; uložení: -

Publikace: Iván - Ölvecky - Rajtár 2019, 229, 243, 247, obr. 9: 12

Popis: Bronzový tyčinkovitý předmět s hráněnou střední částí a hranolovitým článkem ve třetině délky (Iván - Ölvecky - Rajtár 2019, 247)

Rozměry: $\mathrm{D}=105 \mathrm{~mm}$

Materiál: Bronz

Výzkum: V letech 2012 až 2019 v rámci spolupráce Römisch-Germanische Kommission DAI, Archeologického ústavu SAV v Nitre a Katedry archeológie Filozofickej fakulty Univerzity Komenského v Bratislave (Iván - Ölvecky - Rajtár 2019, 229)

Objekt: Hrob 40/2017, žena

Další nálezy: Nože, klíče, nůžky, hliněná urna bez hrdla, slitky z masivní bronzové nádoby, fragmenty soupravy naběračky a cedníku, rozlomené železné nůžky, dva nožíky, pět klíčů, pryskyřice, železné hřebíky, kování dřevěné skříňky, stř́ibrná a bronzová spona, části stř́ibrného hruškovitého závěsku, stř́ibrný prsten, dvě stříbrné zápinky, železný vědérkovitý 
závěsek se stř́ibrnou zápinkou, dva bronzové kapslové závěsky, závěsek s orámováním, kování se závěskem, plechová objímka, kosmetický nástroj, ohnutá jehla a zlomek jehly nebo jehlice, zlomky další kostěné jehlice a fragment hřebene, zlomky skla (IvánÖlvecky - Rajtár 2019, 243)

Datace: ̌̌ B2/C1, 2. pol. 2. stol. n. 1. (Iván - Ölvecky Rajtár 2019, 247)

Původní interpretace: Sonda/specillum (Iván Ölvecky - Rajtár 2019, 247)

Návrh interpretace: Sonda

Vyobrazení: Tab. 3: 39

40. „Nůž a břitvy“; lokalita: Stehelčeves; uložení: NM?, 1: inv. č. 150, 2: inv. č. 151

Publikace: Motyková 1981, 331, 347, 351, obr. 7; Kolník 2004; Pieta 1991

Popis:

1: Rovný železný nůž s jednostrannou rukojetí, která je zakončena profilovanou hlavou. Zadní strana čepele je opatřena 2 otvory (Motyková 1981, 351)

2: Kosočtvercový nůž se zakřiveným držadlem uzavřený srolovaným okem (Motyková 1981, 351)

3: Srpovitá břitva

Rozměry: 1: $\mathrm{d}=126 \mathrm{~mm}, 2: \mathrm{d}=105 \mathrm{~mm}, 3: \mathrm{d}=\mathrm{cca}$ $115 \mathrm{~mm}$

Materiál: Železo

Výzkum: Výzkum A. Knora z roku 1962

Objekt: Hrob „Urn 2“, „U2“ (umístění A); Oválná, mísovitá jáma hloubky $20 \mathrm{~cm}$ s delší osou orientovanou od SZ na JV, rozměry 125x100 cm (Motyková 1981, 347)

Další nálezy: Např. urna, dvousečný železný meč, železný kónický štít s válcovou hlavou, kosočtvercový nůž, bronzová jehla s vázičkovitým profilem (Motyková 1981)

Datace: 1. st. n. 1.

Původní interpretace: „Skalpel (?) se zakřivenou čepelí a očkem“ / „lancetovité nože“ (Kolník 2004, 200)

Návrh interpretace: Břitvy, nůž, kontext ani analogie nenapovídají spojení s chirurgií

Vyobrazení: Tab. 2: 40

41. „Hlavice jehly“; lokalita: Strážnice II, CZ; uložení: Obecní muzeum Ostrožská Lhota

Publikace: Zeman 2017, 302, tab. 106: 6, 158: 18, obr. 47: 11

Popis: Zlomek duté kulovité hlavice s vystupujícím knoflíkem na vrcholu tyčinkovitého nástroje, jejíž tělo je zdobené jemnými rytými geometrickými motivy (Zeman 2017, 302)

Rozměry: $\mathrm{D}=15,8 \mathrm{~mm}$, průměr $=12,7 \mathrm{~mm}$

Materiál: Stříbro

Výzkum: Povrchový sběr v letech 2010-2016 (Zeman 2017)
Objekt: Charakter lokality - sídliště

Další nálezy: -

Datace: -

Původní interpretace: Jehla (Zeman 2017, 160)

Návrh interpretace: Jehlice, šperk

Vyobrazení: Tab. 3: 41

42. „Hlavice jehly“; lokalita: Sudoměřice II, CZ; uložení: Masarykovo muzeum v Hodoníně

Publikace: Zeman 2017, 179, 319, tab. 116: 16, obr. 47: 12

Popis: Fragment profilované hlavice tyčinkovitého nástroje (Zeman 2017, 319)

Rozměry: Průměr 12 mm, d = 21,8 mm (Zeman 2017, 319)

Materiál: Bronz (Cu 43,230 Zn 2,244 Sn 24,949 Ag 0,000 Pb 16,031 Sb 0,314 Fe 3,123; Zeman 2017, 179)

Výzkum: Povrchový sběr v roce 2015 (Zeman 2017, 319)

Objekt: Charakter lokality: sídliště (Zeman 2017, 319)

Další nálezy: -

Datace: -

Původní interpretace: Hlavice bronzového římského tyčinkovitého lékařského nástroje (Zeman 2017, 319) Návrh interpretace: Jehlice, spojení s chirurgií nelze doložit

Vyobrazení: Tab. 3: 42

43. „Lancetovitý nůž“; lokalita: Šoporňa Štrkovec, okr. Galanta, SK, „Burov vršok“" (M-33-144-B-C, 1:25 000 50:230 mm); uložení: Archiv AÚ SAV, P 103636

Publikace: Dekanová 1978; Kolník 2004, 200

Popis: Fragment železného nožíku s tordovaným řapem (trnem)

Rozměry: $\mathrm{D}=108 \mathrm{~mm}$, hm. = 8,02 g + 3,19 oddělené drobné fragmenty

Materiál: Železo

Výzkum: AÚ SAV, záznam dne 18. 9. 1974

Objekt: Urnový hrob 12/74, přír. číslo $12 \mathrm{D}$ (sonda VII/74B, hloubka $65 \mathrm{~cm}$ )

Další nálezy: Urna tvaru terriny, poklice ve tvaru zátky s fragmenty miniaturní nádoby ve tvaru soudkovitého hrnečku s rovně seříznutým okrajem

Datace: Dř (Dekanová 1978)

Původní interpretace: Lancetovitý nůž (Kolník 2004, 200)

Návrh interpretace: Nožík neznámého účelu, spojení s chirurgií nelze doložit

Vyobrazení: Tab. 3: 43

44. „Lancetovitý nůž“; lokalita: Tureň, Kr. Galanta, SK; uložení: -

Publikace: Kolník 2004, 200, Abb. 6:3, Abb. 10C: d

Popis: Nůž lancetovitého tvaru (Kolník 2004) 
Rozměry: -

Materiál: -

Výzkum: -

Objekt: Urnový hrob C

Další nálezy: Nůž, dva železné klíče, urna, zlomek pout

Datace: -

Původní interpretace: Lancetovitý nůž s tordovanou rukojetí

Návrh interpretace: Nožík neznámého účelu, spojení s chirurgií nelze doložit

Vyobrazení: Tab. 3: 44

45. „Hlavice jehly“; lokalita: Vacenovice, CZ; uložení: Soukromá sbírka Miroslava Chludila, Dubňany

Publikace: Zeman 2017, tab. 119: 25, 158: 17, obr. 47: 13

Popis: Fragment části tyčinkovitého artefaktu s rozšířenou hlavicí, s tělem kruhového průřezu a s oběžnými rýhami (Zeman 2017, 323)

Rozměry: Max. š = 13,3 mm, d = $45 \mathrm{~mm}$ (Zeman 2017, 323)

Materiál: Mosaz (Cu 56,283 Zn 13,616 Sn 1,060 Ag 0,000 Pb 11,018 Sb 0,098 Fe 6,658; Zeman 2017, 179)

Výzkum: Nálezové okolnosti: povrchový sběr 19931994, 1998, 2006, 2010, 2012

Objekt: Charakter lokality - sídliště

Datace: DŘ

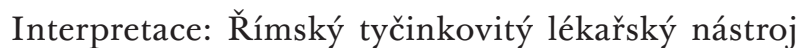
(Zeman 2017, 323)

Návrh interpretace: Úchopová část jehlicovitého artefaktu neznámého účelu

Vyobrazení: Tab. 3: 45

46. „Skalpel se zakřivenou čepelí a očkem“; lokalita: Velatice, okr. Brno-venkov, CZ; uložení: Moravské zemské muzeum Brno

Publikace: Tejral 1970, 128, 134, 170, Obr. 8:7; Kolník 2004, 200

Popis: Nůž s celokovovou rukojetí a závěsným kroužkem. Rukojet' je po stranách a při přechodu k čepeli zdobena jemnými rýhami (Tejral 1970, 134)

Rozměry: -

Materiál: Bronz

Výzkum: V roce 1937 vykopal J. Poulík kostrový hrob, orientovaný S-J (Tejral 1970, 170)

Objekt: Kostrový hrob s kostěnou jehlicí v dřevěném pouzdře u levé ruky a vedle ní bronzovým nožem s celokovovou rukojetí (Tejral 1970, 170)

Další nálezy: Jehla (kost, dřevo) vývalkovitě členěna, s provrtaným kruhovitým otvorem ve středním článku soudkovitého tvaru (Tejral 1970, 128)

Datace: II. a III. fáze stupně B1 na Moravě, 1. s. n. 1. (Tejral 1970, 134)
Původní interpretace: Srpkovitý nůž/břitva (Tejral 1970, 134), „Skalpel (?) se zakřivenou čepelí a očkem" (Kolník 2004, 200)

Návrh interpretace: Nůž neznámého účelu, spojení s chirurgií nelze doložit

Vyobrazení: Tab. 3: 46

47. „Skalpel“; lokalita: Velké Hostěrádky, okr. Břeclav, CZ; uložení: Moravské zemské muzeum Brno, inv. č. Pa 1890/38

Publikace: Ludikovský - Peškař 1978, 86 e, Obr. 4: 4, Tab. 3: 16; Kolník 2004

Popis: Bronzový nůž s trojúhelníkovou čepelí odsazenou od trnu (Ludikozský - Peškař 1978, 88)

Rozměry: D = 126 mm (Ludikovský - Peškař 1978, 88)

Materiál: Bronz (Ludikovský - Peškař 1978, 88)

Výzkum: Objeven rolníkem F. Majerem při orbě na jaře 1929 (Ludikovský - Peškař 1978, 86) a artefakty převzaty M. Chleborádem (Ludikovský - Peškař 1978, 85)

Objekt: Popelnicový hrob 1

Další nálezy: Hliněný ouškovitý výčnělek, bronzové vědro, zlomky bronzových nůžek, zlomek bronzového klíče, bronzová spona, bronzový náramek, stříbrný prsten, část stříbrné jehly (Ludikovský - Peškař 1978, 85)

Datace: Nedatovatelný blíže, podle ostatních nálezů ŘB1/1. pol. 2. stol. (Ludikovský - Peškař 1978, 26)

Původní interpretace: Nůž (Ludikovský - Peškař 1978, 86); skalpel s rovnou a plnou rukojetí (Kolník 2004, 199)

Návrh interpretace: Nůž neznámého účelu, spojení s chirurgií nelze doložit

Vyobrazení: Tab. 2: 47

48. „Skalpel“; lokalita: Zliv (u Libáně), Okr. Jičín, CZ; uložení: Národní muzeum - Stará sbírka, inv. č. 52727

Publikace: Schulz 1887, 73, Taf. 4: 16; Píč 1905, Taf. 55: 16; Kolník 2004, 197, 199; Databáze archeologické sbirky v.4.2

Popis: Zdobený nůž s mírně zakřivenou čepelí, která je od rukojeti oddělena př́čnými žebry (Kolník 2004, 197, 199). Má táhlou jazykovitou rukojet', na užších stěnách ozdobně vyřezávanou. Tři nýty s pečetítkovitou hlavicí zdobenou kruhovitou rýhou přidržovaly dřevěné střenky. Konec rukojeti je zesílen a zdoben př́ičnými, perličkovitými žlábky a oblou brázdou (Databáze archeologické sbírky v.4.2, inv. č. 52727).

Rozměry: $245 \mathrm{~mm}$

Materiál: Bronz?

Výzkum: V roce 1885 byl při orání nalezen v poloze Na pískách dvojitý hrob v opukové snad dvojité skřínce (Píč 1905, 304)

Objekt: Dvojitý žárový hrob s kamenným obložením (Kolník 2004, 197, 199) 
Další nálezy: Bronzový nožík s vykrajovanou a prolomenou základnou čepele a s obloukovitým ostřím, bronzové šídlo se štíhlým jehlancovitým hrotem (Databáze archeologické sbírky v.4.2, inv. č. 52727)

Datace: DǨ, z počátku římské říše (Kolník 2004, 197, 199)

Původní interpretace: Skalpel s rovnou plnou rukojetí (Kolník 2004, 197), nalezeny další dva bronzové nože, které mohly také sloužit jako chirurgický nástroj (Kolník 2004, 197, 199)

Návrh interpretace: Nůž neznámého účelu, spojení s chirurgií nelze doložit

Vyobrazení: Tab. 2: 48

49. „Skalpel“; lokalita: Zohor, okr Malacky, SK; uložení: Slovenské národní muzeum v Martině

Publikace: Kraskovská 1957, 813 Abb. 326, 7; Kolník 1959, 147, Abb. 5, 1; Taf. 2, 6; Kolník 2004,

Popis: Nožík s obloukovitým ostřím, s rukojetí a srpovitým břitem. Obloukovitě prohnutá rukojet' obdélníkového průřezu je na konci čtyřnásobně profilovaná a ukončena polokulovitou hlavicí. Průřez čepele je klínovitý. Na jedné straně čepele jsou nalepená zrnka písku (Kolník 1959, 147)

Rozměry: Max. celková d = $101 \mathrm{~mm}, \max$. š = $17 \mathrm{~mm}$; čepel: d = 40 mm; rukojet': d = 24-28 mm (Kolník 1959, 147)

Materiál: Bronz

Výzkum: Získáno koncem roku 1957 pro Slovenské národní muzeum v Martině od J. Lipára, ředitele školy v Borinke (okr. Bratislava-okolí). Hrob byl rozrušen dne 22. 6. 1957 při kopání písku v poloze „Piesky“. Podle výpovědí dělníků se všechny zachráněné předměty našly u lidské kostry v hloubce asi 2-3 m (Kolník 1959, 144)

Objekt: Ženský kostrový hrob 4 (Kolník 1959, 147)

Další nálezy: Bronzové vědro, pánev, soupravu naběračky a cedníku, skleněnou misku, hliněnou nádobku, bronzový nožík, bronzovou půlměsícovou břitvu, zbytky dřeva, zlomek zviŕecího zubu (Kolník 1959, 144) Datace: Starší doba římská na Slovensku (Kolník 1959, 144)
Původní interpretace: „Skalpel (?) se zakřivenou čepelí a očkem“ (Kolník 2004, 200)

Návrh interpretace: Srpovitá břitva, spojení s chirurgií nelze doložit

Vyobrazení: Tab. 2: 49

\section{Artefakty interpretované jako jiné ,zdravotnické prostředky"}

50. „Hliněný předmět z hrobu ženy“; lokalita: Palárikovo (dříve Slovenský Meder), okr. Nové Zámky (Dolný Kerestrúr/Dolné Križovany), SK; uložení: -

Publikace: Benadik - Rejholec 1974; Benadik 1975, fig. 1; Gardelková-Vrtelová - Ramsl 2018, Fig. 6

Popis: Kruhový hliněný předmět prstencového tvaru. Povrch je hladký bez výzdoby (Gardelková-Vrtelová - Ramsl 2018, 101)

Rozměry: Vnější průměr $58 \mathrm{~mm}$, vnitřní průměr 22 mm, hmotnost 57,2 g (Gardelková-Vrtelová - Ramsl 2018, 101)

Materiál: Hlína (Gardelková-Vrtelová - Ramsl 2018, 101)

Výzkum: Výzkum Emila Rejholce v roce 1974 (Gardelková-Vrtelová - Ramsl 2018, 95)

Objekt: Hrob č. 35, bohatě vybavený, žena 50-60 let (Gardelková-Vrtelová - Ramsl 2018, 97)

Další nálezy: Náramky (bronz, železo, sapropelit), spony, jantarový přívěsek na krku, nánožníky, keramické nádoby (Gardelková-Vrtelová - Ramsl 2018, 97-98)

Datace: LT B2/C1-C1a (Gardelková-Vrtelová - Ramsl 2018, 96)

Původní interpretace: Zdravotní pesar, který se obvykle vyznačuje prstencovým tvarem s hladkým povrchem, vnějším průměrem 55-86 mm a hmotností kolem 100 g (Scherzler 1998)

Návrh interpretace: Analogický předmět k artefaktům podle D. Scherzlera (1998), může odpovídat popsanému účelu Vyobrazení: Tab. 3: 50 


\section{Tabulkové př́lohy: \\ Č́sla v tabulkách odpovídají číslování v katalogu.}
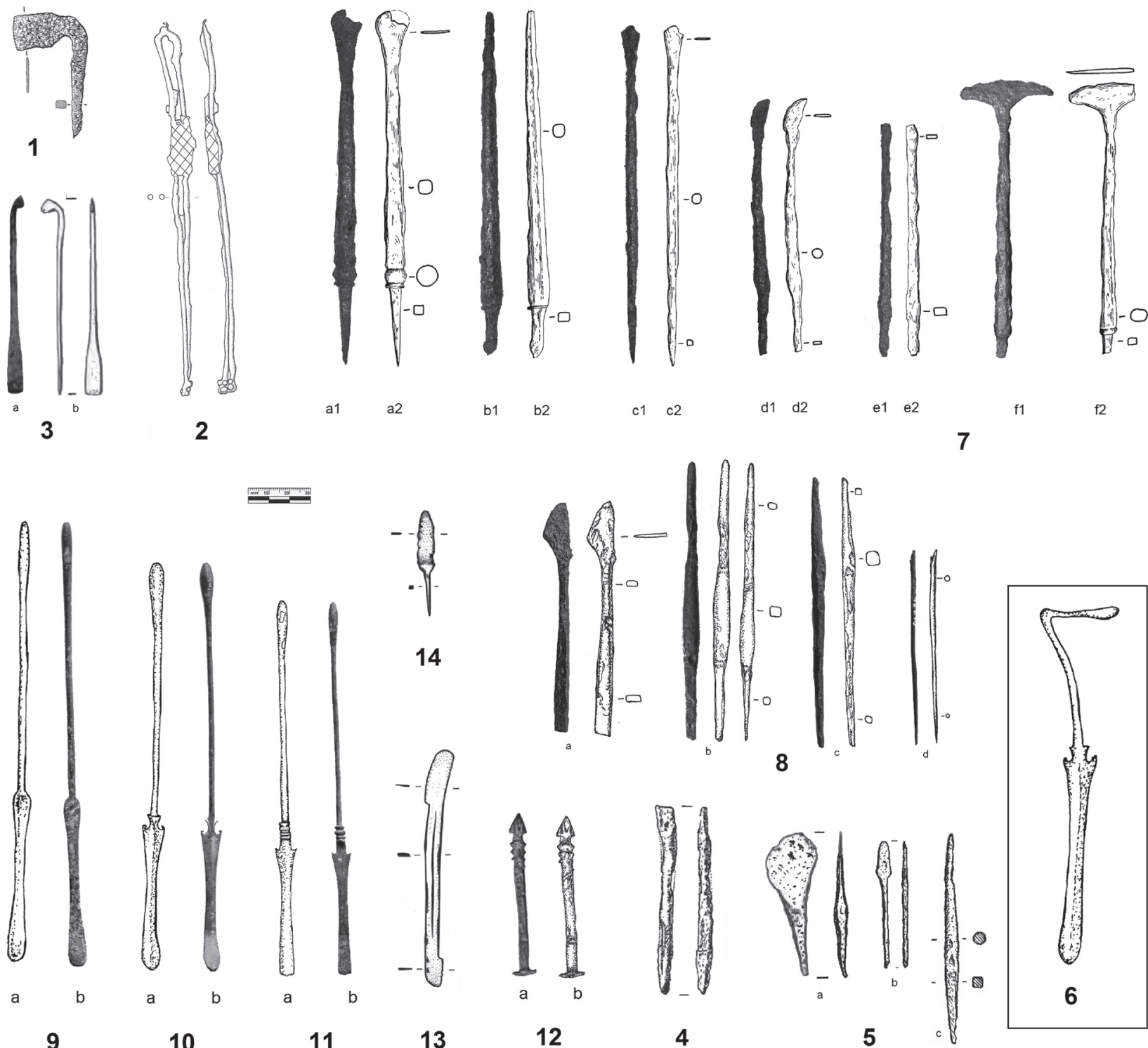

11

13

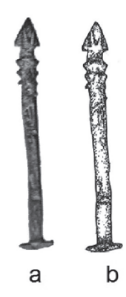

12

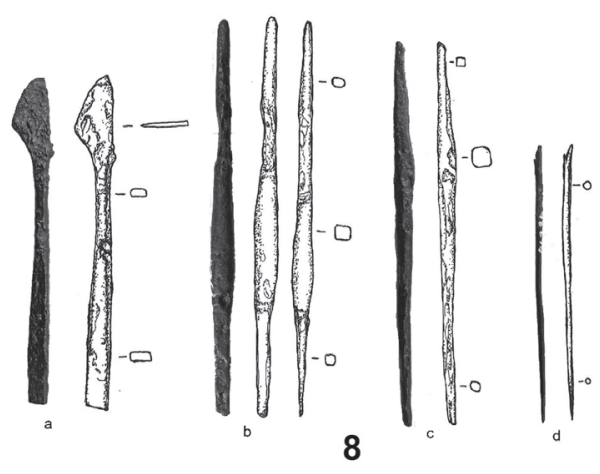

8

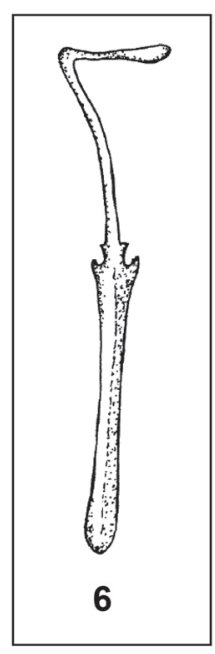

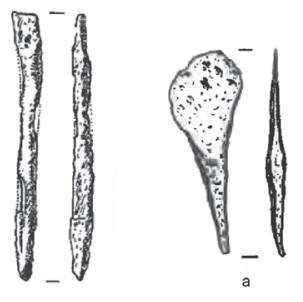

4
5

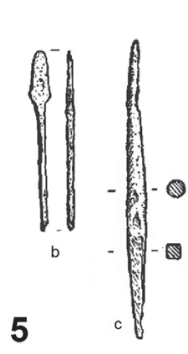

7

Tab. 1: Artefakty interpretované jako nástroje doby železné. - Tab. 1: Artefacts interpreted as Iron Age instruments. Kat. č. 1 Pila (Parzinger - Nekvasil - Barth 1995, obr: 426); Kat. č. 2 Drátěný předmět (Pecinovská - Baloun - Sankot 2014, Obr. 7: A); Kat. č. 3 „Lékařský bronzový nástroj“ a: Jansová (1965, Obr. 22:11), b: Jansová (1992, 201:20); Kat. č. 4 Železné dlátko (Jansová 1992, Tab. 203: 4); Kat. č. 5 Tři železné nástroje (Jansová 1986, Taf. 18: 16, 17, 18); Kat. č. 6 Spatula, Oberleiserberg, upraveno podle Kern (1996, Abb. 8), bez měřítka; Kat. č. 7 Sada nástrojů, kresby (a2, b2, c2, d2, e2, f2) provedl Karol Pieta, fotografie a1, b1, c1, d1, e1 poř́dila autorka práce se souhlasem K. Piety, vyobrazení f1 upraveno dle Pieta (2008, F 24); Kat. č. 8 Sada nástrojů, fotografie a kresby pořízeny autorkou práce na základě badatelské smlouvy s Muzeem Dr. B. Horáka v Rokycanech, které je součástí Západočeského muzea v Plzni; Kat. č. 9 Spatula, Stradonice, inv. č. Národního muzea 81 459, a: kresba podle (Databáze archeologické sbírky v.4.2); b: fotografie (Píc 1903, Tab. XXIV:10); Kat. č. 10 Spatula, Stradonice, inv. č. 81 460, a: kresba podle (Databáze archeologické sbírky v.4.2); b: fotografie (Pí̌ 1903, Tab. XXIV:9); Kat. č. 11 Spatula, Stradonice, inv. č. 81 461, a: kresba podle (Databáze archeologickésbírky v.4.2); b: fotografie (Píc 1903, Tab. XXIV:11); Kat. č. 12 Phlebotom, Stradonice, a: fotografie (Píč 1903, Tab. XXIV:12), b: kresba (podle fotografie Píc 1903, Tab. XXIV:12); Kat. č. 13 „Skalpel“ (Kysela 2011, Obr. 2: 7); Kat. č. 14 „Skalpel“ (Kysela 2011, Obr. 2: 8). 

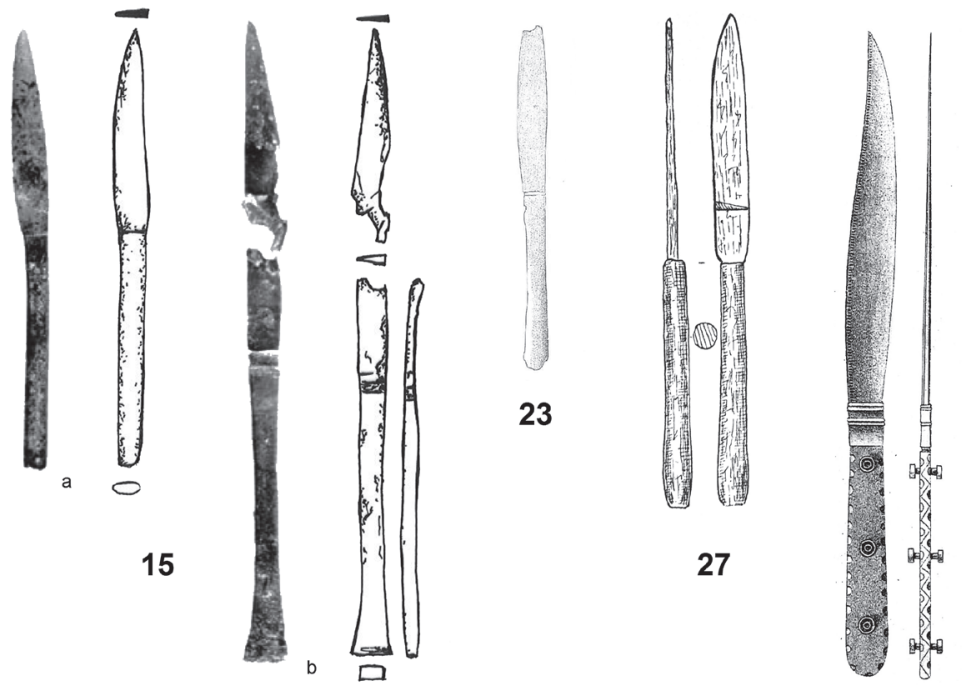
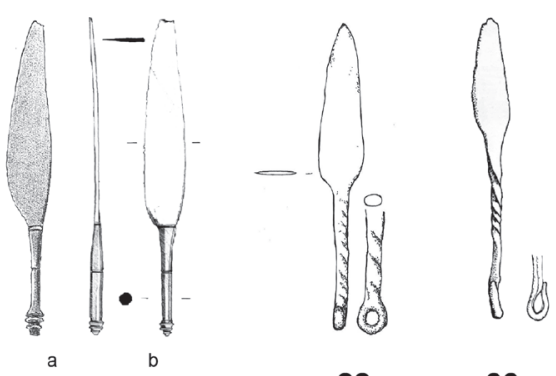

36

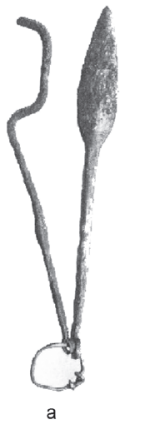

25
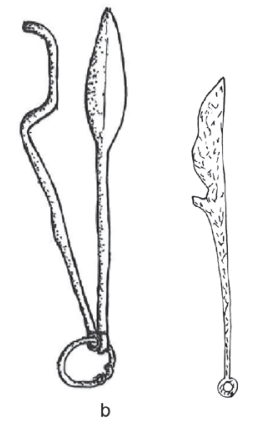

26

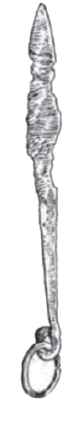

32

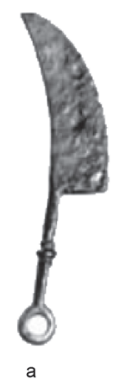

16
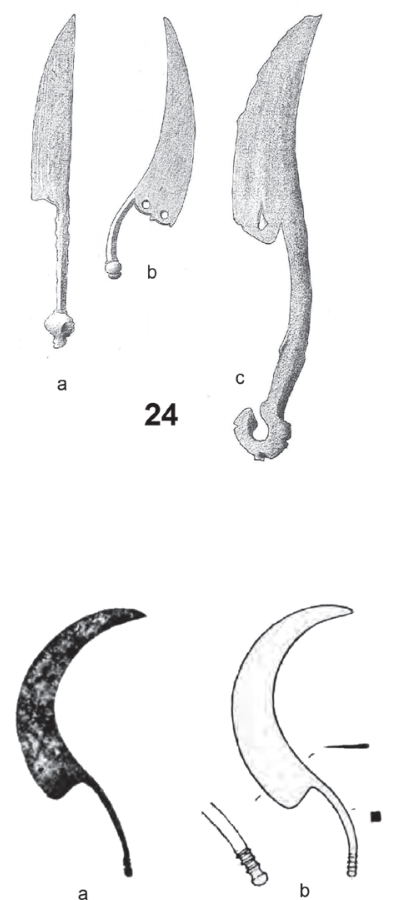

49
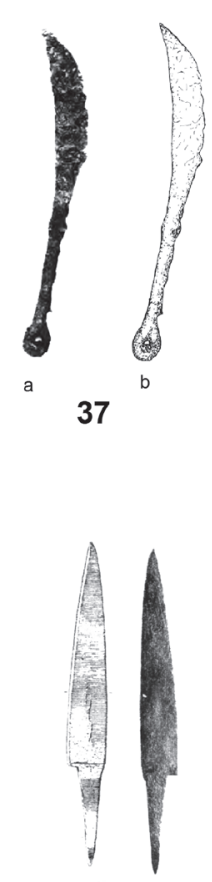

47

Tab. 2: Artefakty interpretované jako nástroje doby ř́mské. - Tab. 2: Artefacts interpreted as Roman Period instruments.

Kat. č. 15 Nože, a: nůž z hrobu 14 (fotografie a upravená kresba podle Kolník 2004, Abb. A: 2, Abb. 2: 14e); b: nůž z hrobu 87 (fotografie a upravená kresba podle Kolník 2004, Abb. 1: 1, Abb. 2: 87c), kresby upraveny kvůli nízkému rozlišení ve zdroji; Kat. č. 16 Skalpel se zakřivenou čepelí a očkem, a: fotografie (Kolník 2004, Abb. 6:1); b: kresba (podle fotografie Kolník 2004, Abb. 6:1); Kat. č. 17 Nůž se zakřivenou čepelí (Pollak 1980, Taf. 1: 1); Kat. č. 21 Srpkovitý nůž (Tejral 1970, obr. 13:4); Kat. č. 22 Lancetovitý nůž (upraveno podle Kolník 2004, Abb. 11: 14); Kat. č. 23 Nůž (Píc 1905, Taf. LXXX: 25); Kat. č. 24 Nože a břitvy. a: kresba Pič (1905, Tab. LXX: 18); b: kresba Píc (1905, Tab. LXXIII: 4), c: kresba Píč (1905, Tab. LXXXIII: 24); Kat. č. 25 Lancetovitý nůž, a: fotografie (Bóna 1963, 243 Taf. XLIII: 15); b: kresba (upraveno podle Kolník 2004, Abb. 12:6); Kat. č. 26 Nůž (Pollak 1980, Taf. 14:2); Kat. č. 27 Nůž (Zeman 1961, Obr. 81 D: e); Kat. č. 32 Nủž (Tejral 1971, obr. 5: 2); Kat. č. 33 Upraveno podle (Pieta - Ruttkay 1997, Abb. 3:14); Kat. č. 36 Nůž, a: kresba f. L. Píće (1905, Tab. XLIX: 15), b: kresba M. Černého (2009, 2); Kat. č. 37 Břitva, a: fotografie (Lámiová-Schmiedlová 1969, Abb. 11: 20); b: kresba (podle fotografie Lámiová-Schmiedlová 1969, Abb. 11: 20); Kat. č. 40 Nůž a břitvy, a: nůž, kresba podle Motyková (1981, 331, obr. 7: 1); b: břitva, kresba podle Motyková (1981, 331, Obr. 7: 5); c: břitva, kresba podle Motyková (1981, 331, Obr. 7: 6), kresby upraveny kvůli nízkému tiskovému rozlišení ve zdroji; Kat. č. 47 Nůž (Ludikovský - Peškař 1978, Obr. 4: 4, Tab. 3: 16); Kat. č. 48 Nůž (Píč 1905, Taf. 55: 16. 16a); Kat. č. 49 „Skalpel“, a: fotografie (Kolník 1959, Taf. 2, 6); b: kresba (Kolník 1959, 174 Abb. 5: 1). 


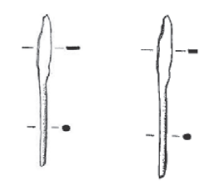

19 20

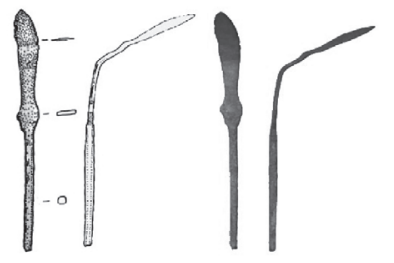

29

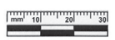

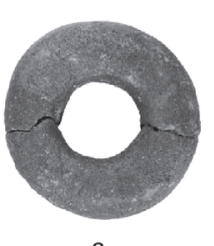

a

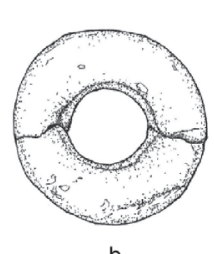

b

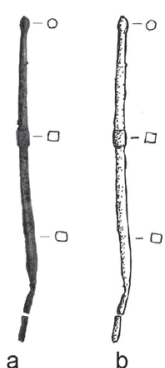

39

50

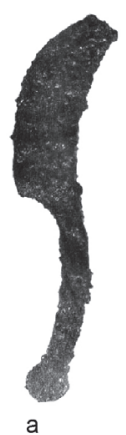

28

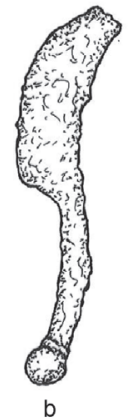

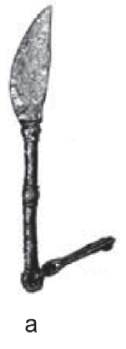

34

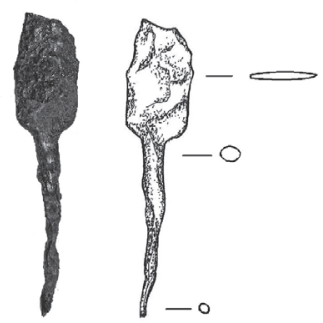

43

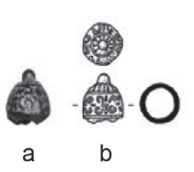

18

41

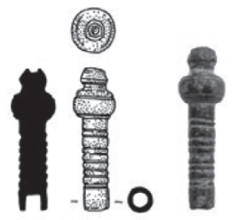

45

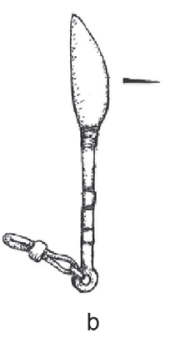

4

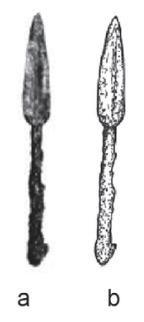

35

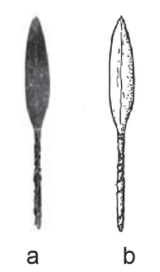

44
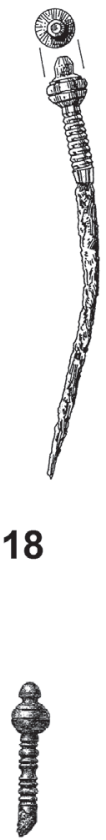

31

Tab. 3: Artefakty interpretované jako nástroje doby římské a artefakt interpretovaný jako „zdravotnický prostředek“. Tab. 3: Artefacts interpreted as Roman Period instruments and an artefact interpreted as a "medical tool".

Kat. č. 18 Jehlicovitý bodec s profilovanou hlavicí (fílek 2004, Obr. 3:3); Kat. č. 19 Spatula (Elschek 2017, Taf. 119:2); Kat. č. 20 Bronzová spatula (Elschek 2017, 146, Taf. 36), poznámka: vyobrazení se jeví stejné, jako u předmětu v tabulce 119 (Elschek 2017, Taf. 119:2), jeden artefakt má ale pocházet ze sběrů, druhý z objektu 6/88; Kat. č. 28 „Skalpel“, a: fotografie (Eisner 1933, Taf. LXVIII: 1); b: kresba (podle fotografie Eisner 1933, Taf. LXVIII: 1), bez měřítka; Kat. č. 29 Spatula (Hladíková 2019, obr. 2:1a, 1b); Kat. č. 31 Jehlicovitý artefakt, kresba (fílek 2004, Obr. 1); Kat. č. 34 Nůž, a: fotografie (Kolník 2004, Abb. 6:2), bez měřítka; b: kresba (podle kresby v nízkém tiskovém rozlišení v Kolník 2004, Abb. 6:2), bez měřítka; Kat. č. 35 Nůž, a: fotografie (Kolník 2004, Abb. 6:4) bez měřítka; b: kresba (podle Kolník 2004, Abb. 6:4); Kat. č. 38 Držadlo (Fojtík - JílekPopelka 2015, Obr. 2: 1); Kat. č. 39 Sonda, a: fotografie (Iván - Ölvecky - Rajtár 2019, obr. 9:12); b: kresba (podle Iván Ölvecky - Rajtár 2019, obr. 9:12); Kat. č. 41 Zlomek jehlice, a: fotografie (Zeman 2017, tab. 106: 6); b: kresba (Zeman 2017, tab. 158: 18); Kat. č. 42 Jehlice (Zeman 2017, tab. 116:16, obr. 47:12); Kat. č. 43 Fotografie a kresba pořízena se souhlasem prof. Janky Hečkové; Kat. č. 44 Nůž, a: fotografie (Kolník 2004, 1: Abb. 6:3), bez měřítka; b: kresba (upraveno podle kresby Kolník 2004, Abb. 10C: d), bez měřítka; Kat. č. 45 Tyčinkovitý nástroj (Zeman 2017, tab. 119: 25, 158:17, obr. 47:13); Kat. č. 46 Nůž, kresba (Tejral 1970, Obr. 8:7), bez měřítka; Kat. č. 50 Hliněný předmět, a: fotografie (Gardelková-Vrtelová - Ramsl 2018, Fig. 6); b: kresba (podle fotografie Gardelková-Vrtelová - Ramsl 2018, Fig. 6) 


\section{Literatura}

Adler, H. - Schmelzenbarth, F. 1991: KG Petronell, MG Petronell-Carnuntum, VB Bruck an der Leitha. Fundberichte aus Österreich 30, 300-301.

Adler, H. 1992: KG Berhardsthal. Fundberichte aus Österreich 30, 281.

Baker, P. A. 2004: Roman Medical Instruments: Archaeological Interpretations of their Possible 'Nonfunctional uses'. Social History of Medicine 17, 3-21.

Baker, P. A. 2013: The archaeology of medicine in the Greco-Roman world. Cambridge.

Balassone, G. et al. 2018: Multi-analytical characterization and provenance identification of protohistoric metallic artefacts from Picentia-Pontecagnano and the Sarno valley sites. Measurement 128, 104-118.

Benadik, B. - Rejholec, E. 1971: Výskumná správa 6968/74. Dokumentácia AÚ SAV v Nitre. Nitra 1974. Palárikovo.

Benadik, B. 1975: Keltské pohrebisko v Palárikove. AVANS $\mathrm{v}$ roku 1974, 22-25.

Bliquez, L. f. 2003: The Hippocratic surgical instrumentarium: A study in nomenclature. Medicina nei secoli 15 3, 403-439.

Bliquez, L. 2014: The tools of Asclepius: surgical instruments in Greek and Roman times. Leiden.

Bóna, I. 1963: Beiträge zur Archäologie und Geschichte der Quaden. Acta Arch. Acad. Scien. Hungaricae 15, 239-307.

Bostock, f. - Riley, H. T. 1855: Pliny the elder. The natural history 2.

Brambilla, G. A. 1781: Ioan. Alexand. Brambilla. Instrumentarium chirurgicum Viennense, oder, Wiennerische chirurgische Instrumenten Sammlung. Gedruckt bey Matthias Andreas Schmidt. Vídeň.

Břeň, f. 1975: Pánve tzv. aylesfordského typu v Čechách. Časopis Národního muzea, Řada historická 144, 7-15.

Břeň, f. 1984: Keltové v jižních Čechách. Katalog výstavy. České Budějovice.

Corruccini, R. S. - Pacciani, E. 1991: Ortodonzia e occlusione dentale negli Etruschi. Studi Etruschi 57, 3, 189-194.

Černý, M. 2009: Pohřebiště ze starší doby římské v Ohništanech (okr. Hradec Králové). Praha.

Databáze archeologické sbirky v.4.2 [cit. 31. 10. 2019]: Oddělení prehistorie a protohistorie Národního muzea. Dostupný z http://forum.nm.cz/prehistorie/index_ph.php.

Davidson, Gladys R. 1952: Corinth. Volume XII. The Minor Objects. Athens.

Dekanová, J. 1978: Šoporňa Štrkovec, okr. Galanta. (Nálezová zpráva.) Archív AÚ SAV Nitra, č. 8583/78.

Drda, P. - Rybová, A. 1998: Keltové a Čechy. Praha.

Droberjar, E. 1999: Dobřichov - Pičhora. Ein Brandgräberfeld der älteren römischen Kaiserzeit in Böhmen (Ein Beitrag zur Kenntnis des Marbod-Reichs). Fontes Arch. Pragenses 23.

Droberjar, E. 2006: Hornolabští Svébové-Markomani. K problematice dalšího vývoje großromstedtské kultury ve stupni Eggers B1 („Zeitgruppe 3 “) v Čechách (dobřichovská skupina). Archeologie ve stř́edních Čechách 10, 599-712.

Duda, M. - Niederle, B. 2000: Práce sestry na operačním sále. Praha.

Eggers, H. F. 1932: Ein frühkaiserzeitlicher Grabfund von Poggendorf, Kreis Grimmen, Vorpommern. Prähistorische Zeitschrift 23, 248-260.

Eggers, H. F. 1951: Der römische Import im freien Germanien. Atlas d. Urgesch 1. Hamburg.

Eisner, f. 1933: Slovensko v pravěku. Bratislava.
Elschek, K. 2017: Bratislava-Dúbravka im 1. bis 4. Jahrhundert n. Chr: germanischer Fürstensitz mit römischen Bauten und germanische Besiedlung. Nitra.

Faria, Miguel A. 2015: Neolithic trepanation decoded-A unifying hypothesis: Has the mystery as to why primitive surgeons performed cranial surgery been solved?. Surgical neurology international 6, 72 .

Florea, L. 2013: The Monstrous Musical Body: Mythology and Surgery in Late Medieval Music Theory. Philobiblon: Transylvanian Journal of Multidisciplinary Research in Humanities 18, 1.

Fojtík, P. - Fílek, f. - Popelka, M. 2015: Držadlo římského (lékařského?) nástroje z prostoru krátkodobého tábora z Hulína-Pravčic, okr. Kroměříž. Pravěk NŘ 23, 183-193, Brno.

Fritze, H. E. 1843: Miniatur - Armamentarium oder Abbildungen der wichtigsten akiurgischen Instrumente. Mit einer Vorrede von Dieffenbach. Berlin.

Ganz, f. C. 2017: Intracranial Epidural Bleeding: History, Management, and Pathophysiology. Academic Press.

Gardelková-Vrtelová, A. - Ramsl, P. C. 2018: Remarkable Burial of a Female with Signs of Medical Care at the Cemetery of Palárikovo. Študijné zvesti 63, 95-106.

Golec, M. 2015: Prehistorie a historie jeskyně Býčí skály a blízkého okolí od neolitu po současnost. In: M. Oliva et al. (ed.), Jeskyně Býčí skála ve svých dějích a pradějích, Anthropos. Studies in Anthropology, Palaeoethnology, Palaeontology and Quaternary Geology 39, 31, 115-153.

Golec, M. 2017: The Phenomenon of Býčí Skála Cave: Landscape, Cave and Mankind. Olomouc.

Gostenčnik, K. 2001: Medizinische Instrumente aus dem römischen Kärnten.

Gostenčnik, K. 2002: Medizinische Instrumente vom Magdalensberg in Kärntner. Antichità altoadriatiche 51, 161-177.

Gostenčnik, K. 2004: Die medizinische Versorgung in der Stadt auf dem Magdalensberg. In: G. Piccottini (ed.), Die Ausgrabungen auf dem Magdalensberg: 1986 bis 1990. Verlag des Geschichtsvereines für Kärnten, Klagenfurt.

Gostenčnik, K. 2013: Medizinische Instrumente aus Lauriacum in den Sammlungen der Oberösterreichischen Landesmuseen. Römisches Österreich 36, 95-107.

Grasselt, T. 1994: Die Siedlungsfunde der vorrömischen Eisenzeit von der Widderstatt bei Jüchsen in Südthüringen. Weimarer Monographien zur Ur- und Frühgeschichte Bd. 31.

Härtl, P. 2005: Die besondere Bedeutung und Behandlung des menschlichen Kopfes innerhalb der Latènekultur Mittel- und Westeuropas. Bonn.

Heisters, L. D. 1724: Chirurgie, In welcher Alles, was zur Wund-Artzney gehöret, Nach der neuesten und besten Art gründlich abgehandelt und In vielen Kupffer-Tafeln die neu-erfundene und dienlichste Instrumenten Nebst den bequemsten Handgriffen der Chirurgischen Operationen und Bandagen deutlich vorgestellet werden. Norimberk.

Hladíková, K. 2019: Medicínsky alebo toaletný nástroj? Nález špachtlovitej sondy (spatuly) v kontexte germánskeho osídlenia polohy Za Vŕškom v Malackách. In: J. Mellnerová Šuteková - P. Pavúk - M. Bača (eds.), SALVE, EDVARDE! A Toast to the Jubilee of Professor E. Krekovič, Studia Archaeologica et Mediaevalia, Tomus XII. Bratislava, 89-96.

Hobert, L. - Binello, E. 2017: Trepanation in ancient China. World neurosurgery 101, 451-456. 
Iván, R. - Ölvecky, R. - Rajtár, F. 2019: Vybrané hrobové celky z germánskeho žiarového pohrebiska v Sekuliach. Zborník Slovenského Národného múzea CXIII-2019. Archeológia 29.

Fackman, M. - Novak, I. - Lannin, N. 2014: Effectiveness of functional hand splinting and the cognitive orientation to occupational performance (CO-OP) approach in children with cerebral palsy and brain injury: two randomised controlled trial protocols. BMC neurology 14 , $1,144$.

Fackson, R. 1988: Doctors and diseases in the Roman Empire. London.

facobi, G. 1974: Werkzeug und Gerät aus dem Oppidum von Manching. Die Ausgrabungen in Manching 5. Wiesbaden.

Fakielski, K. E., - Notis, M. R. 2000: The metallurgy of Roman medical instruments. Materials characterization $45,4-5,379-389$.

Jansová, L. 1965: Hrazany-keltské oppidum na Sedlčansku. Praha.

Jansová, L. 1986: Hrazany. Das keltische Oppidum in Böhmen. Die Befestigung und die anliegende Siedlungsbebauung. Praha.

Jansová, L. 1992: Hrazany. Das keltische Oppidum in Böhmen. Band III. Die Besiedlung der Abhänge der Červenka. Praha.

fílek, f. 2004: Jehlicovitý lékařský nástroj z Mušovska v kontextu středního Podunají. Přehled výzkumů 45 , 33-38.

Firki̊, f. - Pazdziora, E. 2006: Vlastnosti chirurgických a stomatologických nástrojů, jejich ošetřování, sterilizace a manipulace s nimi. Nové Město na Moravě.

fohns C. H. W. 1904: Babylonian and Assyrian Laws, Contracts and Letters (Library of Ancient Inscriptions 6). Facsimile 1987. New York.

Kábrt, Jan - Kábrt, Jan jr. 2004: Lexicon medicum. Praha.

Kern, A. 1996: Spatlatènezeitliche Funde vom Oberleiserberg, MG Ernstbrunn, N O. In: E. Jerem et al. (eds.), Die Kelten in den Alpen und an der Donau, Akten des Internationalen Symposions St. Polten 1992. Budapest - Wien, 385-393.

Kolník, T. 1959: Germánske hroby zo staršej doby rímskej zo Zohora, Žlkoviec a Kostolnej pri Dunaji. Slovenská Arch. 7, 144-162.

Kolník, T. 1964: Stredné Považie v mladšej dobe rímskej. Rukopis kandidátské práce. Nitra.

Kolník, T. 1980: Römerzeitliche Gräberfelder in der Slowakei. Teil I. Arch. Slovaca Fontes 14. Bratislava.

Kolnik, T. 2004: Das mitteldanubische Barbaricum-eine Brücke zwischen Zentrum und Peripherie am Beispiel der medizinischen Messerfunde. Verlag der Österreichischen Akademie der Wissenschaften, 195-210.

Kraskovská, L'. 1957: Nové nálezy rímskych pamiatok v Zohore. Arch. Rozhledy 9, 813-814.

Krška, Z. - Hoskovec, D. - Petruželka, L. 2014: Chirurgická onkologie. Praha.

Kučerová, I. 2012: Bašt' „Nad Dvorem 2010“. (Konzervátorská a restaurátorská zpráva.) Archiv nálezových zpráv Archeologického ústavu AV ĆR v Praze, TP 2012-2435.

Künzl, E. 1983: Medizinische Instrumente aus Sepulkralfunden der römischen Kaiserzeit. Cologne: Rheinland-Verlag, 5-6.

Künzl, E. - Hassel, F. 7. - Künzl, S. 1983: Medizinische Instrumente aus Sepulkralfunden der römischen Kaiserzeit. Bonn.

Künzl, E. 1995: Medizin der Kelten. Ein archäologischer Forschungsbericht. In: R. Bedon - P. M. Martin (eds.),
Mélanges Raymond Chevalier 2: Histoire \& Archéologie 2. Caesarodunum XXIX. Tours, 221-240.

Künzl, E. 2002: Medizinische Instrumente der römischen Kaiserzeit im Römisch-Germanischen Zentralmuseum. Mainz.

Kysela, f. - Militký, J. 2018: Dálkové kontakty ve světle importovaných výrobků. In: J. Kysela - J. Militký - M. Tisucká (ed.), Keltové: Čechy v 8. až 1. století před Kristem. Praha.

Kysela, f. 2011: Středomořské importy z oppida Tř́sov. Archeologické výzkumy v Jižních Čechách 24, 163-190.

Lamiová-Schmiedlová, M. 1969: Römerzeitliche Siedlungskeramik in der Südostslowakei. Slovenská Arch. 17, 403-501.

Ludikovský, K. - Peškař, I. 1978: Žárové pohřebiště z doby řimské ve Velkých Hostěrádkách (o. Břeclav). Studie AUU B IV/2. Praha.

Milne, F. S. 1907: Surgical instruments in Greek and Roman times.

Minozzi, S. et al. 2007: A gold dental prosthesis of Roman imperial age. The American journal of medicine 120, 5 , e1-e2.

Motyková, K. 1981: Das Brandgräberfeld der römischen Kaiserzeit von Stehelčeves. Pam. Arch. 72, 340-415.

Parapia, L. A. 2008: History of bloodletting by phlebotomy. British journal of haematology 143, 4, 490-495.

Parzinger, H. - Nekvasil, f. - Barth, F. E. 1995: Die Býčí skála-Höhle: ein hallstattzeitlicher Höhlenopferplatz in Mähren. Römisch-Germanische Forschungen 54.

Pecinovská, M. - Baloun, L. - Sankot, P. 2014: Laténské pohřebiště v Bašti, okr. Praha-západ. Archeologie ve středních Čechách 18, 745-766.

Pérez-Cambrodí, R. F. et al. 2015: Hollow needle cataract aspiration in antiquity. Acta ophthalmologica 93, 8, 782-784

Peška, J. - Tejral, J. - Von Carnap-Bornheim, C. 2002: Das germanische Königsgrab von Mušov in Mähren 1, 1-131.

Píč, J. L. 1903: Starožitnosti země České II, 2. Hradiště u Stradonic jako historické Marobudum. Praha.

Píč, J. L. 1905: Starožitnosti země České II, 3. Žárové hroby v Čechách a příchod Čechů. Praha.

Pieta, K. - Ruttkay, M. 1997: Germanische Siedlung aus dem 4. und 5. Jh. in Nitra-Párovské Háje und Probleme der Siedlungskontinuität. In: J. Tejral - H. Friesinger M. Kazanski (Hrsg.), Neue Beiträge zur Erforschung der Spätantike im mittleren Donauraum. Spisy Archeologického ústavu AV ČR Brno 8, Brno, 145-163.

Pieta, K. 1991: The North Carpatians at the beginning of the Migration Period. Antiquity 65, 274, 376-387.

Pieta, K. 2008: Keltské osídlenie Slovenska. Mladšia doba laténska. Nitra.

Pollak, M. 1980: Die germanischen Bodenfunde des 1.-4. Jahrhunderts n. Chr. im nördlichen Niederösterreich. Stud. z. Ur- u. Frühgesch. d. Donau u. Ostalpenraumes 1. Phil.-Hist. Kl. 147. Wien.

Ramsl, P. C. 2002: Das eisenzeitlische Gräberfeld von Pottenbrunn. Forschungsansätze zu wirtschaftlichen Grundlagen und sozialen Strukturen der latènezeitlichen Bevölkerung des Traisentales, Niederösterreich. Fundberichte aus Österreich, Materialheft A 11, 91-94.

Riha, E. 1986: Römisches Toilettgerät und medizinische Instrumente aus Augst und Kaiseraugst. Forschungen in Augst 6. Augst.

Riha, E. 1990: Der römische Schmuck aus Augst und Kaiseraugst. Forschungen in Augst Bd. 10. Augst.

Saber, A. 2010: Ancient Egyptian surgical heritage. Journal of Investigative Surgery 23, 6, 327-334. 
Shaw, f. - Sykes, N. 2018: New directions in the archaeology of medicine: deep-time approaches to human-animal-environmental care. World Archaeology 50, 3.

Scherzler, D. 1998: Der tönerne Ring vom Viesenhäuser Hof. Ein Hinweis auf medizinische Versorgung in der Vorrömischen Eisenzeit? Fundberichte aus Baden-Württemberg 22, 237-294.

Schmit, E. 1926: Découverte d'un Pessaire dans une Sépulture d'un cimetière à faciès Hallstattien-Champenois à La Veuve (Marne). Bulletin de la Société Archéologique Champenoise 20, 56-58.

Schulz, V. 1887: Hrob u Zlivi. Pam. Arch. 13, 66-80.

Sklenár, K. 1986: Okresní muzeum v Rokycanech - katalog pravěké sbírky, Zprávy ČSSA 31. Praha.

Stloukal, M. 1981: Anthropologische Funde aus der Býčí skála-Höhle. Anthropologie 19, 2, 111-114.

Svobodová, H. 1985: Antické importy z keltských oppid v Čechách a na Moravě. Archeologické rozhledy 37, 653-677.

Tejral, f. 1970: Počátky doby římské na Moravě z hlediska hrobových nálezů. Stud. Zvesti Arch. ústavu 18, 107-192.
Tejral, f. 1971: Př́ispěvek k datování moravských hrobových nálezů ze sklonku starší doby římské a počátku mladší doby římské. Slovenská archeológia XIX-1, 27-93.

Vytejčková, R. et al. 2015: Ošetřovatelské postupy v péči o nemocné II. Praha.

Weller, U. - Kaiser, H. - Heynowski, R. 2016: Kosmetisches und medizinisches Gerät: erkennen, bestimmen, beschreiben. Deutscher Kunstverlag, Bestimmungsbuch Archäologie. Berlin.

Zeman, f. 1961: Severní Morava v mladší době římské. Mon. Arch. 9. Praha.

Zeman, T. 2017: Střední Pomoraví v době římské: svědectví povrchové prospekce. Olomouc.

Lucie Burešová

Ústav dějin lékařství a cizích jazyků 1. LF UK

U Nemocnice 4

12108 Praha 2 